(2) norden 



\section{Tillægsforsikringer i Norden}

Peter Møgelvang-Hansen og Søren Sandfeld Jakobsen

TemaNord 2006:524 


\section{Tillægsforsikringer i Norden}

TemaNord 2006:524

(C) Nordisk Ministerråd, København 2006

ISBN 92-893-1303-X

Tryk: Kun tilgængelig som Print-on-Demand.

Publikationen kan bestilles på www.norden.org/order. Flere publikationer på www.norden.org/publikationer

Nordisk Ministerråd

Store Strandstræde 18

1255 København K

Telefon (+45) 33960200

Fax (+45) 33960202

www.norden.org

\section{Nordisk Råd}

Store Strandstræde 18

1255 København K

Telefon (+45) 33960400

Fax (+45) 33111870

\section{Det nordiske samarbejde}

Det nordiske samarbejde er et af de ældste og mest omfattende regionale samarbejder i verden. Det omfatter Danmark, Finland, Island, Norge og Sverige samt Færøerne, Grønland og Åland. Samarbejdet styrker samhørigheden mellem de nordiske lande med respekt for de nationale forskelle og ligheder. Det øger mulighederne for at hævde Nordens interesser i omverdenen og fremme det gode naboskab.

Samarbejdet blev formaliseret i 1952 med Nordisk Råds oprettelse som forum for parlamentarikerne og regeringerne i de nordiske lande. I 1962 underskrev de nordiske lande Helsingforsaftalen, som siden har været den grundlæggende ramme for det nordiske samarbejde. I 1971 blev Nordisk Ministerråd oprettet som det formelle forum til at varetage samarbejdet mellem de nordiske regeringer og de politiske ledelser i de selvstyrende områder, Færøerne, Grønland og Åland. 


\section{Indhold}

Forord

Resumé.

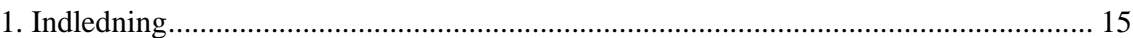

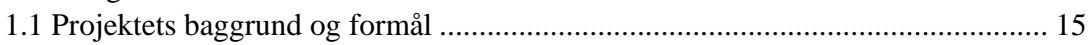

1.2 Terminologi, metode og afgrænsning ............................................................. 16

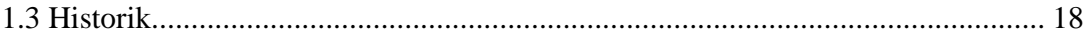

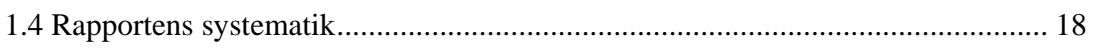

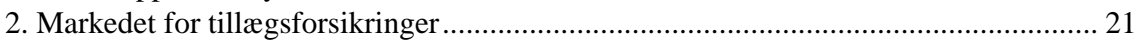

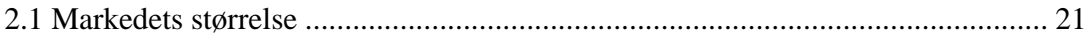

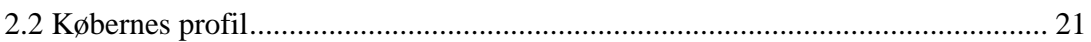

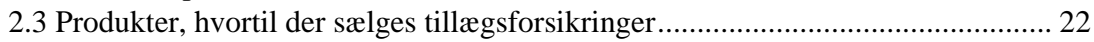

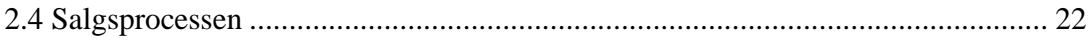

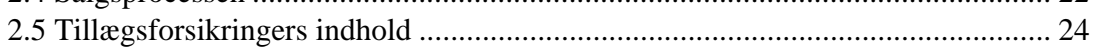

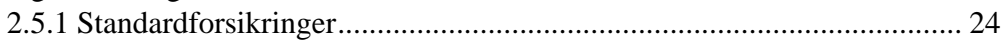

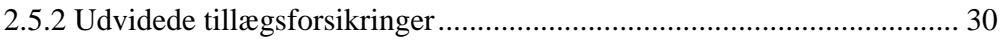

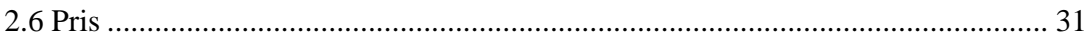

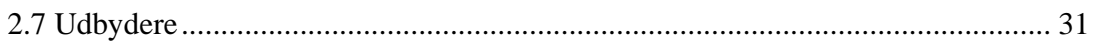

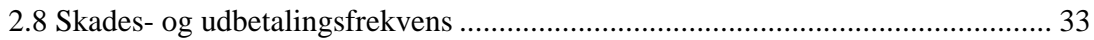

2.9 Særligt om ligheder og forskelle mellem de nordiske lande.................................... 33

2.10 Sammenfatning vedrørende markedet for tillægsforsikringer ............................. 35

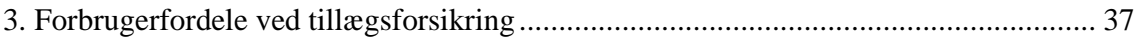

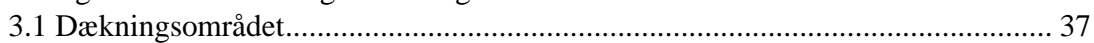

3.1.1 Tillægsforsikringsbegivenheden ctr. køberetlige regler om mangler ..... 37

3.1.2 Tillægsforsikringsbegivenheden ctr. garantidækning ............................ 42

3.1.3 Tillægsforsikringsbegivenheden ctr. indboforsikringsdækning.............. 43

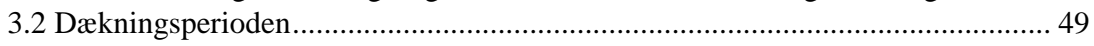

3.2.1 Tillægsforsikringstiden ctr. køberetlige regler om reklamation.............. 49

3.2.2 Tillægsforsikringstid ctr. garantiperiode .............................................. 52

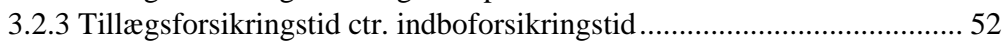

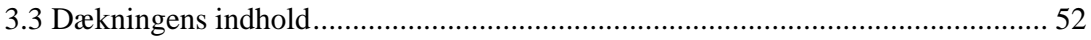

3.3.1 Tillægsforsikringsydelsen og indboforsikringsydelsen ........................... 52

3.3.2 Tillægsforsikringsydelsen ctr. køberetlige mangelsbeføjelser

og garantibeføjelser............................................................................ 55

3.4 Sammenfatning: Hvad opnår forbrugeren ved tillægsforsikringen? ........................ 57

3.4.1 Fordele ift. beskyttelsen efter købeloven og en eventuel garanti............ 57

3.4.2 Fordele ift. en eventuel indboforsikring ……......................................... 58

4. Forbrugerbeskyttelse ved tegning og aktivering af tillægsforsikringer.......................... 61

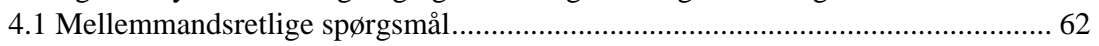

4.1.1 Detailforretningens aftaleretlige status .................................................. 62

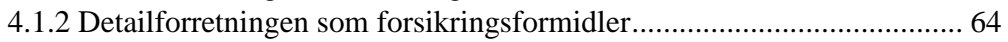

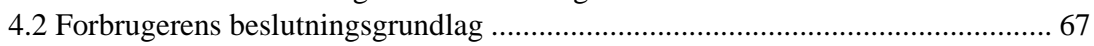

4.3 Fejl og mangler i forbrugerens beslutningsgrundlag ......................................... 71

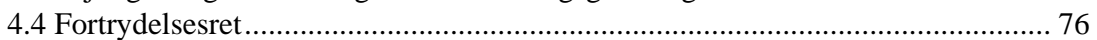

4.5 Forbrugerens dobbeltrolle som køber og forsikringstager ................................... 77

4.6 Tillægsforsikringers førtidige ophør.................................................................... 79

4.7 Vildledende/urimelige vilkår i tillægsforsikringer............................................. 81

4.7.1 Eksempler på vildledende/urimelige vilkår ................................................ 82

4.7.2 Vilkår, der kan give forbrugeren skuffede forventninger ....................... 84 


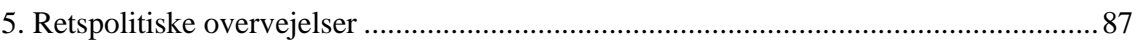

5.1 Tillægsforsikringer som forbrugerretspolitisk problem ...................................... 87

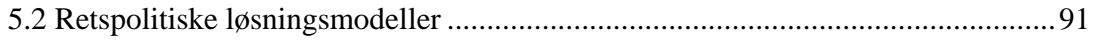

5.3 Forbrugerproblemer ved køb af tillægsforsikringer og nogle løsningsforslag. .....93

Tiivistelmä 99

Samantekt 105

Summary. .111

Bilag 1: Udbydere af tillægsforsikringer i de nordiske lande 117

Bilag 2: Eksempler på tillægsforsikringer.

Standard-tillægsforsikringer (med links til elektronisk udgave)

119

Udvidede tillægsforsikringer 


\section{Forord}

Rapporten indgår i det nordiske projekt „Tillægsforsikringer ved varekøb“. Projektet er gennemført i perioden januar 2005-marts 2006 for midler bevilget af Nordisk Ministerråd. Arbejdet med rapporten er gennemført under en projektgruppe bestående af

Charlotte Lemche Jensen, projektleder (Forbrugerstyrelsen, Danmark) Lars Arent Nielsen og Tina Morell Nielsen (Forbrugerstyrelsen, Danmark)

Annette Højrup, Forbrugerrådet (Danmark) (i oktober 2005 afløst af Tina Dhanda)

Gunveig Planting-Visa, Konsumentverket (Finland)

Eiríkur Áki Eggertsson, Konsumentförbundet (Island) (i februar 2006 afløst af Anna Birna Halldórsdóttir, Neytendastofa)

Helga Skofteland, Forbrukerrådet (Norge)

Nils Ahlén, Konsumentverket (Sverige) (i februar 2006 afløst af Camilla Tellås)

Udredere har været Peter Møgelvang-Hansen og Søren Sandfeld Jakobsen, begge Juridisk Institut, CBS, Handelshøjskolen i København.

Projektgruppens opgave har i hovedsagen været at levere materiale vedrørende de enkelte landes lovgivning og praksis samt andet input. Fremstillingen og konklusionerne er udredernes. 



\section{Resumé}

Denne rapport er udarbejdet som led i et nordisk projekt under Forbrugerstyrelsen i Danmark med titlen „Tillægsforsikringer ved varekøb“. Projektet er gennemført for midler bevilget af Nordisk Ministerråd.

Projektet og rapporten har til formål at analysere området for tillægsforsikringer ved varekøb i Norden. Den indeholder en kortlægning af markedet for tillægsforsikringer, en analyse af forbrugernes kendskab til og behov for tillægsforsikringer samt retspolitiske overvejelser.

Ved tillægsforsikringer forstås i rapporten en forsikring, der er knyttet til et bestemt produkt, som en forbruger - samtidig med forsikringen erhverver i en detailforretning. Andre forsikringer, der vedrører løsøre, men som ikke tegnes i en detailforretning, for eksempel almindelige indboforsikringer eller fjernsalg af forsikringer, falder uden for projektet.

Markedet for tillægsforsikringer beskrives i rapportens kapitel 2 på grundlag af oplysninger indhentet gennem medlemmerne af projektgruppen eller fra ministerier/styrelser, klagenævn, relevante interesseorganisationer, artikler i pressen, tv-udsendelser, tilgængelig information på Internettet med videre.

De for udrederne tilgængelige oplysninger tyder på, at de nordiske forbrugere som helhed køber en tillægsforsikring i ca. 1/3 af alle køb, hvor en tillægsforsikring udbydes. Det indebærer, at der hvert år tegnes 3-3,5 mio. tillægsforsikringer i Norden. Det er vanskeligt at estimere den samlede omsætning hidrørende fra dette salg, navnlig da der ikke foreligger offentligt tilgængelige tal fra branchen. At der er tale om en årlig samlet omsætning på i hvert fald ikke under 1 mia. DKK synes dog ubetænkeligt at lægge til grund. Der er således tale om et marked af en ikke ubetydelig størrelse.

For Danmarks, Norges og Sveriges vedkommende viser rapporten, at markedet for tillægsforsikringer er præget af de samme karakteristika, og at det i det store hele er de samme forbrugerproblemer, der gør sig gældende. Der foreligger kun sparsomme oplysninger om forholdene i Finland og Island. De forskelle, der eksisterer mellem de nordiske landes respektive forbrugerlovgivninger, for eksempel i henseende til længden af den absolutte køberetlige reklamationsfrist eller eksistensen af en fortrydelsesret ved salg af forsikringer, afspejler sig naturligt nok i affattelsen af tillægsforsikringer i de enkelte lande.

Tillægsforsikringer sælges først og fremmest i tilknytning til husholdningsprodukter, hårde hvidevarer og de fleste former for forbrugerelektronik. Der sælges dog også tillægsforsikringer til visse andre typer af produkter, herunder mobiltelefoner og briller. 
Tillægsforsikringer sælges gennem detailleddet sammen med det produkt, som forsikringen knytter sig til. Der betales for tillægsforsikringen samtidig med, at der betales for hovedproduktet. Salg af tillægsforsikringer formidles, dvs. gennemføres, på forsikringsselskabets vegne af salgspersonalet i den detailforretning, hvor produktet købes. Den nødvendige information om tillægsforsikringen, dens dækningsomfang og varighed i forhold til reklamationsretten efter købeloven, forholdet til forbrugerens øvrige forsikringer osv., skal således gives af salgspersonalet.

For formidlingen af tillægsforsikringen modtager detailforretningen en provision fra forsikringsselskabet (som er forbrugerens aftalepart i relation til tillægsforsikringen). Provisionen er ofte ganske betydelig, hvilket selvsagt skaber et ekstra incitament for detailforretningen til at sælge tillægsforsikringer i tilknytning til et varekøb.

Tillægsforsikringer sælges under mange betegnelser. De kan systematisk inddeles i to overordnede kategorier, en standardforsikring henholdsvis en udvidet forsikring. Der kan konstateres meget store forskelle på udformningen af de enkelte tillægsforsikringer.

Standard-tillægsforsikringers dækningsomfang adskiller sig sjældent væsentligt fra de fejl og mangler, som forbrugeren kan reklamere over efter købelovens reklamationsregel. Forskellen ligger typisk i, at tillægsforsikringen kan have en længere dækningsperiode end varigheden af reklamationsfristen. I nogle tilfælde dækker tillægsforsikringen dog tillige skader eller andre forsikringsbegivenheder, som reklamationsretten ved mangler ikke dækker. Til gengæld er der som regel andre vilkår i tillægsforsikringen, for eksempel vedrørende afskrivning og selvrisiko, som i realiteten indebærer, at forbrugeren stilles ringere end efter de køberetlige reklamationsregler.

Sammenlignet med standard-tillægsforsikringerne har de udvidede tillægsforsikringer typisk et større dækningsomfang, mindre eller ingen selvrisiko, mindre eller ingen løbende nedskrivning af anskaffelsesværdien eller andre fordele. Den øgede dækning modsvares dog naturligvis af en højere pris for udvidede tillægsforsikringer.

Prisen for en tillægsforsikring udgør som oftest 10-20\% af prisen for det forsikrede produkt. For forbrugerprodukter i den billige ende kan tillægsforsikringen dog relativt set være væsentligt dyrere, ligesom den for meget dyre forbrugerprodukter kan være relativt set væsentligt billigere.

Tillægsforsikringer er mest udbredt blandt større detailkæder, herunder navnlig dem, der breder sig over de fleste former for hårde hvidevarer og/eller forbrugerelektronik. Mange af de detailkæder, der formidler tillægsforsikringer, er tvær-nordiske. Ligeledes er de bagvedliggende forsikringsselskaber, med hvem forbrugeren - via detailforretningen - indgår forsikringsaftalen, typisk de samme på tværs af de nordiske lande. Kredsen af forsikringsselskaber, der udbyder tillægsforsikringer i samarbejde med detailleddet, synes at være forholdsvis beskeden. 
Forskellige oplysninger tyder på, at tillægsforsikringer bliver udnyttet i 30-40 \% af de tilfælde, hvor en forsikring er tegnet. De produkter, hvor tillægsforsikringer oftest udnyttes, er fjernsyn i de højeste prisklasser, vaskemaskiner/tørretumblere og opvaskemaskiner. De produkter, der mest sjældent udløser en tilkøbt tillægsforsikring, er komfurer, køle- og fryseskabe samt musikanlæg i de laveste prisklasser.

Det springende punkt i relation til tillægsforsikringer er, i hvilken udstrækning de giver forbrugeren en reel fordel, henset til den „risikoafdækning” forbrugeren allerede er sikret som følge af de køberetlige regler om mangler, en eventuel garanti afgivet af sælger/producenten samt den indboforsikring, som langt hovedparten af husstande i Norden efter det oplyste er i besiddelse af. Disse spørgsmål er behandlet i rapportens kapitel 3.

Sammenligningen af de i praksis forekommende tillægsforsikringer med køberetlige regler om mangler kan sammenfattes i, at tillægsforsikringerne typisk ikke giver forbrugeren større tryghed i tilfælde af kvalitetssvigt end de køberetlige regler, før end der er forløbet en vis længere tid efter købet. Hvor lang tid der herved kommer på tale, beror i første række på varens karakter. Den „mertryghed“, der kan komme på tale, kan bestå i:

- At tillægsforsikringstiden er længere end købelovgivningens absolutte reklamationsfrist, dvs. to år (Danmark), 3 år (Sverige), 5 år (efter omstændighederne dog kun to) år (Island og Norge); i Finland er der slet ingen absolut reklamationsfrist.

- I kraft af tillægsforsikringen kan forbrugeren, når der er gået mere end seks måneder efter købet, alt efter omstændighederne opnå en vis bevismæssig fordel bestående i, at relevant faktuel tvivl med hensyn til årsagen til funktionssvigt med videre juridisk kommer forbrugeren til gode.

Forbrugeren opnår dog ikke den mertryghed, der følger af de anførte punkter, i det omfang varen er omfattet af sælgerens eller tredjemands garantitilsagn. Desuden står forsikringsdækningen normalt ikke mål med den „dækning”, forbrugeren kan opnå efter køberetlige regler. Dette beror dels på, at tillægsforsikringerne ofte indeholder regler om selvrisiko, nedskrivning med videre, dels det forsikringsretlige berigelsesforbud.

- De begivenheder, der kan udløse tillægsforsikringsdækning, omfatter i nogle, men ikke alle tilfælde, i et vist omfang også udefra kommende begivenheder indtruffet efter risikoens overgang til forbrugeren (uden at det skyldes, at sælgeren har tilsidesat sine forpligtelser efter aftalen). Dette er en fordel for forbrugeren, medmindre sådanne begivenheder er omfattet af forbrugerens indboforsikring med videre. 
Sammenlignes dækningen efter en tillægsforsikring med dækningen efter en indboforsikring, kan det først konstateres, at indboforsikringers typiske dækningsområder er brand- og vandskader, tyveri og hærværk, dvs. udefra kommende begivenheder, der forårsager beskadigelse eller ødelæggelse af tingen. Tillægsforsikringers typiske dækningsområde er derimod funktionsfejl, nedbrud og lignende, dvs. fejl ved selve tingen. I udgangspunktet er der således ikke overlapning mellem de to typer af forsikringer.

Dette billede ændres imidlertid ofte i praksis som følge af de mange tilvalgsmuligheder, som såvel indbo- som tillægsforsikringer rummer, og som i realiteten ofte udjævner forskellen på de to typer forsikringer. Den enkelte forbruger kan på den baggrund have vanskeligt ved at fastslå, hvilket tillæg forsikringen reelt yder til den beskyttelse, forbrugeren i forvejen nyder godt af. De særlige omstændigheder, hvorunder tillægsforsikringerne tegnes i detailleddet, nemlig som et accessorium til købet af den pågældende vare, er egnet til at forstærke forbrugerens vanskeligheder i så henseende.

Dette rejser spørgsmålet, om de gældende forbrugerbeskyttelsesregler giver forbrugeren et betryggende beslutningsgrundlag, når det skal besluttes, om der skal købes en tillægsforsikring. Dette spørgsmål behandles i rapportens kap. 4.

Nordiske forbrugere er ved køb af en tillægsforsikring beskyttet af en række regler i forsikringslovgivningen, aftale-, forbrugeraftale- og markedsføringslovgivningen samt af generelle kontraktretlige grundsætninger.

De forbrugerbeskyttende regler forpligter bl.a. forsikringsselskaberne og detailforretningerne til at give forbrugeren en række væsentlige oplysninger om forsikringen, herunder om dennes forhold til den eksisterende beskyttelse efter købelovgivningen og om risikoen for overlapning med en eventuel tegnet indboforsikring, dvs. dobbeltforsikring.

Derudover sikrer de forbrugerbeskyttende regler i et vist omfang, at der kan gribes ind, såfremt aftalen indgås på grundlag af vildledende oplysninger, eller den indeholder urimelige vilkår. Endvidere har forbrugerne i Danmark 14 dages fortrydelsesret; i de øvrige nordiske lande er forbrugerens fortrydelsesret begrænset til fjernsalg.

Forbrugeren nyder således allerede i dag en ikke ubetydelig retlig beskyttelse ved tegning af tillægsforsikringer. Spørgsmålet er imidlertid, om reglerne i praksis er tilstrækkelige til at sikre forbrugeren det fornødne grundlag for at vurdere, om der i den konkrete situation er en reel fordel forbundet med at købe en tillægsforsikring. De retspolitiske spørgsmål om forbrugerproblemer ved tillægsforsikringer og nogle forskellige løsningsmuligheder behandles i rapportens kap. 5 .

Tillægsforsikringerne befinder sig i et for de fleste forbrugere vanskeligt tilgængeligt krydsfelt mellem købe- og forsikringsret. Henset hertil og til de omtalte temmelig specielle praktiske forhold, hvorunder tillægs- 
forsikringerne tegnes, synes der at være tale om beslutninger, hvor selv det relativt fintmaskede net af oplysningskrav med videre i praksis ofte ikke er i stand til at sikre forbrugeren et betryggende beslutningsgrundlag.

Konsekvensen heraf synes at være en nærliggende risiko for, at forbrugeren ved tegningsbeslutningen på grund af usikkerheden angående det eventuelle behov for forsikringen ikke tør undlade at købe tillægsforsikringen „for alle eventualiteters skyld“. Meget taler derfor for, at retspolitiske tiltag kan være nødvendige for at sikre de nordiske forbrugere en tilstrækkelig beskyttelse ved tegning af tillægsforsikringer.

I kap. 5 peges afslutningsvis på en række forskellige problemfelter og forskellige mulige løsningsforslag.

Overordnet set peges på, at det som alternativ/supplement til egentlige lovændringer bør overvejes i et samarbejde mellem erhvervs- og forbrugerorganisationer samt forbrugermyndigheder at opstille konkretiserede retningslinjer i form af „skabeloner“ for

- tillægsforsikringsvilkår indeholdende dels en række overordnede principper, som alle tillægsforsikringer bør efterleve, dels forslag til affattelsen af de mest almindelige vilkår i en tillægsforsikring

- den skriftlige information til forbrugerne om forholdet mellem tillægsforsikringsdækningen og forbrugerens minimumsbeskyttelse efter den køberetlige lovgivning samt nogle af de mest udbredte typer af indboforsikringsdækning, således at disse spørgsmål så vidt muligt belyses gennem praktisk relevante, konkrete eksempler.

En „skabelonisering“ af tillægsforsikringsvilkårene kunne bl.a fremme en vis standardisering (og sammenlignelighed) gennem opstilling af acceptable formuleringer af en række vilkår, som erfaringsmæssigt indgår i tillægsforsikringer. På den anden side er det selvsagt vigtigt, at skabelonen ikke bliver en spændetrøje, som modvirker konkurrence på pris og dækningsomfang.

Idet der er tale om soft law regulering, ville det være frivilligt for de enkelte selskaber og detailforretninger, om de ville følge skabelonerne og de overordnede principper. Manglende overholdelse heraf ville dog efter omstændighederne kunne udgøre en overtrædelse af god markedsføringsskik og/eller god forsikringsskik og på den måde udløse fremadrettede sanktioner efter de offentligretlige regler i henholdsvis markedsføringsog forsikringslovgivningen.

Et af de mere specifikke forbrugerpolitiske problemer, der peges på i kap. 5, består i, at tillægsforsikringer på grund af regler om selvrisiko med videre skaber risiko for, at forbrugerkøbere gennem tegning af tillægsforsikringer i praksis kommer til at betale for at nyde godt af de rettigheder, de har efter køberetlige regler, og som de allerede har betalt for gennem købesummen for hovedydelsen. 
Som en mulig løsning skitserer rapporten et forslag om forbud mod tillægsforsikringsvilkår, som fastsætter selvrisiko i tilfælde af dækning af funktionsfejl med videre i en periode svarende til den absolutte reklamationsfrist angående mangler, dvs. i Danmark (2 år), og måske Sverige (3 år). I Finland (hvor der ikke er nogen absolut reklamationsfrist) samt i Island og Norge, hvor reklamationsfristen i det overvejende antal praktiske tilfælde er 5 år, kunne et forbud mod selvrisiko eventuelt sættes til 2 eller 3 år, svarende til den periode, hvor det gennemsnitligt set kan forventes, at forbrugerens bevismæssige fordele ved aktivering af tillægsforsikringen frem for køberetlige mangelsregler kan have væsentlig praktisk betydning. 


\section{Indledning}

\subsection{Projektets baggrund og formål}

Denne rapport er udarbejdet som led i et nordisk projekt under Forbrugerstyrelsen i Danmark med titlen „Tillægsforsikringer ved varekøb“. Projektet er gennemført for midler bevilget af Nordisk Ministerråd med professor Peter Møgelvang-Hansen og adjunkt, ph.d. Søren Sandfeld Jakobsen, begge Juridisk Institut, CBS, Handelshøjskolen i København som udredere. Projektet blev startet i januar 2005 og er afsluttet i marts 2006.

Projektets praktiske udførelse er foregået via en styregruppe med deltagelse af følgende repræsentanter fra de nordiske lande:

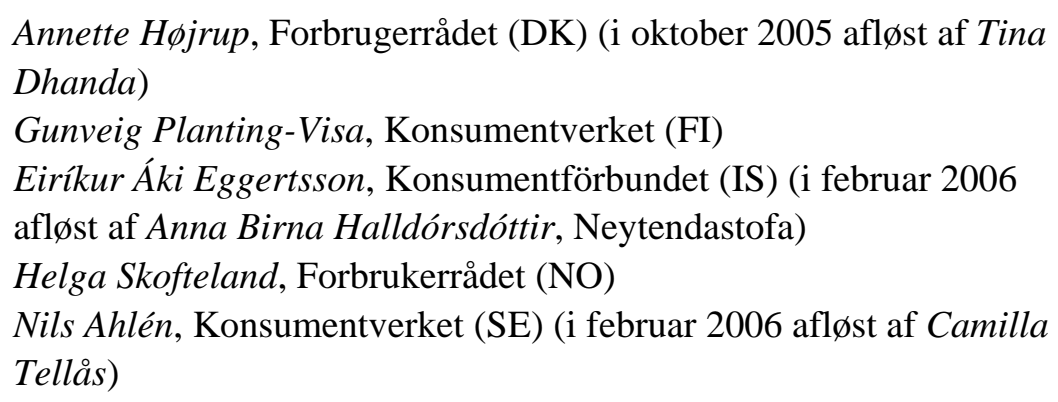

Styregruppen har afholdt et indledende møde med udrederne. Herefter er kommunikationen foregået skriftligt.

Styregruppens opgave har i hovedsagen været at levere materiale vedrørende de enkelte landes lovgivning og praksis samt andet input. Fremstillingen og konklusionerne er udredernes.

Forbrugerstyrelsen (DK) har været sekretariat for styregruppen. Fra Forbrugerstyrelsen har deltaget fuldmægtig Lars Arent Nielsen og specialkonsulent Tina Morell Nielsen.

Projektets formål har været at foretage en analyse af området for tillægsforsikringer ved varekøb i Norden. Forbrugerstyrelsen har som led heri anmodet udrederne om at udarbejde nærværende rapport. Rapporten skal ifølge Forbrugerstyrelsens opdrag indeholde en kortlægning af markedet for tillægsforsikringer, herunder i relation til 1) typer af forsikringer, 2) de brancher, inden for hvilke forsikringerne benyttes, samt 3) tegningsfrekvens og andre statistiske forhold om markedets størrelse. Ud over kortlægning af markedet skal forbrugernes kendskab til og behov for tillægsforsikringer analyseres.

Hypotesen bag projektet om tillægsforsikringer er, at der i de senere år er sket - og fortsat sker - en stigning i anvendelsen af tillægsforsikringer, 
dvs. forsikringer, der tegnes i en detailforretning i forbindelse med køb af et forbrugerprodukt, og som sikrer forbrugeren i tilfælde af funktionsfejl, nedbrud og andre begivenheder, der rammer produktet.

Stigningen i salget af tillægsforsikringer sker på trods af, at forbrugerne har opnået bedre rettigheder med ændringen af købelovgivningen i 2002 som følge af forbrugerkøbsdirektivet (direktiv 99/44/EF). Disse forbedrede rettigheder, navnlig den beskyttelsespræceptive 2-årige reklamationsret i tilfælde af fejl og mangler ved et produkt, burde for en umiddelbar betragtning mindske behovet for tillægsforsikringer. Derfor er det fundet relevant at undersøge anvendelsen af tillægsforsikringer, herunder de forudsætninger ud fra hvilke forbrugerne tegner sådanne forsikringer.

Der foreligger så vidt vides ingen større, systematiske undersøgelser af markedet for tillægsforsikringer i Norden og forbrugernes kendskab til og behov for tillægsforsikringer. Fænomenet er ligeledes kun yderst sparsomt beskrevet i litteraturen, herunder den juridiske litteratur.

\subsection{Terminologi, metode og afgrænsning}

Ved tillægsforsikringer forstås i denne rapport en forsikring, der er knyttet til et bestemt produkt, som en forbruger - samtidig med forsikringen erhverver i en detailforretning. Andre forsikringer, der vedrører løsøre, men som ikke tegnes i en detailforretning, for eksempel almindelige indboforsikringer, er således ikke omfattet af begrebet tillægsforsikringer i nærværende sammenhæng.

Datagrundlaget for denne rapport består af tilgængelige eller indhentede oplysninger fra medlemmer af arbejdsgruppen, ministerier/styrelser, klagenævn, relevante interesseorganisationer, artikler i pressen, tilgængelig information på internettet med videre. Det bemærkes, at der kun foreligger sparsomme oplysninger for Finlands og, i særdeleshed, Islands vedkommende. Der tages derfor et generelt forbehold for, at de konklusioner, der drages i rapporten, er behæftet med en vis usikkerhed for så vidt angår disse lande.

Det er væsentligt at understrege, at rapportens faktuelle oplysninger om markedet for tillægsforsikringer ikke hviler på et statistisk repræsentativt eller på anden måde videnskabeligt dokumenteret grundlag. Dette skyldes, at der ikke efter udredernes oplysninger foreligger et sådant datamateriale, og at det har ligget uden for rammerne af udredningsarbejdet at søge et omfattende og repræsentativt datamateriale tilvejebragt.

Udrederne anmodede ved brev af 23. september 2005 en række af de største udbydere af tillægsforsikringer samt en række relevante interesseorganisationer om oplysninger vedrørende markedet for tillægsforsikringer i Norden. Udrederne modtog imidlertid ingen oplysninger på bag- 
grund af henvendelsen, angiveligt primært af den årsag, at der er tale om konkurrencefølsomme oplysninger.

Det talmateriale, der ligger til grund for markedsbeskrivelsen, stammer derfor i vid udstrækning fra 2000-2003, hvor tillægsforsikringer fra tid til anden gav anledning til offentlig debat, og hvor der derfor fra visse forbrugermyndigheders og forbrugerorganisationers side blev foretaget nogle (ikke-videnskabelige) undersøgelser. Enkelte nye oplysninger er dog fremkommet siden da, og det er i det hele udredernes opfattelse, at manglen på helt nye data ikke ændrer på markedsundersøgelsens væsentligste konklusioner.

Beskrivelsen af selve indholdet af de forskellige tillægsforsikringer er baseret på en gennemgang af en lang række tillægsforsikringer fra de største markedsaktører i de nordiske lande, jævnfør bilag 1 og 2. Tillægsforsikringer fremtræder i mange variationer med mange små nuanceforskelle, hvilket gør det vanskeligt at tegne et samlet billede af begrebet „en tillægsforsikring“. På trods heraf er det udredernes vurdering, at beskrivelsen i rapporten giver et pålideligt indtryk af hovedlinierne i de fleste forekommende tillægsforsikringer.

Rapporten vedrører tillægsforsikringer i hele Norden. Af omfangsmæssige hensyn vil hvert land ikke blive gennemgået for sig. I stedet omtales eventuelle forskelle på forholdene i de enkelte nordiske lande i den kontekst, hvori de indgår. Endvidere vil kun væsentlige forskelle landene imellem blive fremdraget. Hvor ikke andet fremgår, angår beskrivelsen således alle de nordiske lande. Som det vil fremgå, lettes en tværnordisk beskrivelse af tillægsforsikringer af, at der er betydelige lighedstræk landene imellem, bl.a. som følge af, at de store detailkæder, der udbyder tillægsforsikringer, opererer i hele Norden. Hertil kommer de samfundsmæssige, økonomiske og juridiske ligheder, der i almindelighed præger de nordiske lande.

På den anden side foreligger der, som allerede nævnt, for Finlands og Islands vedkommende kun sparsomme oplysninger om tillægsforsikringer og markedet for disse sammenlignet med de øvrige nordiske lande, hvilket i relation til Finland og Island behæfter konklusionerne med nogen usikkerhed.

Selv om der som nævnt på det overordnede plan er væsentlige lighedstræk med hensyn til indholdet af de forskellige tillægsforsikringer, er der på det mere detaljerede plan endog meget store forskelle på de enkelte forsikringers nærmere vilkår, opbygning, sprogbrug, detaljeringsgrad osv. Ikke blot forskelle fra land til land og udbyder til udbyder, men også fra produkt til produkt. Vilkårene for en tillægsforsikring knyttet til en mobiltelefon kan afvige betydeligt fra samme udbyders tillægsforsikring knyttet til et TV-apparat. Det gør det svært at sammenligne forsikringerne og bidrager i det hele taget til at gøre markedet for tillægsforsikringer svært gennemskueligt. 
Når dette er fastslået, er hovedlinierne i de fleste tillægsforsikringer dog som antydet så ens, og de relevante lovregler i de nordiske lande så identiske, at det trods alt giver mening at foretage en samlet analyse af fænomenet tillægsforsikringer og de retlige og retspolitiske overvejelser, tillægsforsikringer giver anledning til. Det skal blot understreges, at der er en lang række nuancer og forskelle på de enkelte tillægsforsikringer, som af gode grunde ikke vil fremgå af rapporten.

De juridiske analyser i rapporten hviler på en traditionel retsdogmatisk metode, hvor de relevante retskilder i de nordiske lande - love, administrative forskrifter, sædvaner, praksis med videre - analyseres og fortolkes i relation til tillægsforsikringer. De retspolitiske overvejelser i rapportens afsnit 5 - om mulige ændringer af de gældende regler for at imødegå de juridiske problemer, som tillægsforsikringer rejser - udtrykker alene udredernes vurderinger og overvejelser angående eventuelle løsningsmuligheder, om end medlemmerne af projektgruppen har haft lejlighed til at kommentere disse løsningsforslag.

\subsection{Historik}

Der foreligger ikke klare oplysninger om, hvornår tillægsforsikringer på forbrugerprodukter fremkom på markedet i de nordiske lande. Selve det, at der udbydes særlige forsikringer knyttet til bestemte produkter, er imidlertid et fænomen, der kan spores mange år tilbage. I fjernsynets tidlige år var det således udbredt at tegne en såkaldt „,billedrørsforsikring“, der - som følge af den betydelige udgift til et nyt billedrør - i en periode efter købet dækkede fejl, nedbrud med videre ved billedrøret. Udbyderne af disse forsikringer omfattede bl.a. lytter- og seerforeninger.

Tillægsforsikringer, som begrebet forstås i nærværende rapport, dvs. som produktforsikringer, der tegnes i detailleddet sammen med købet af det produkt, forsikringen vedrører, er af nyere dato, men har dog været kendt i mindst 10-15 år. Når denne type forsikring først nu påkalder sig særlige interesse, skyldes det formentlig dels en stærk stigning i udbredelsen af tillægsforsikringer, dels den forøgede forbrugerbeskyttelse efter købeloven, der rejser spørgsmål om eventuel overlapning mellem på den ene side den beskyttelse, man køber sig via en tillægsforsikring, og på den anden side den beskyttelse, man automatisk nyder efter købelovgivningen, dvs. uden betaling af noget særligt vederlag.

\subsection{Rapportens systematik}

I overensstemmelse med opdraget for udarbejdelsen af denne rapport er rapporten således opbygget, at markedet for tillægsforsikringer i Norden først undersøges, jævnfør kapitel 2. Markedsundersøgelsen fokuserer 
både på markedsstørrelse og andre traditionelle økonomiske forhold samt på selve indholdet af de forskellige typer af tillægsforsikringer. Idet salgsprocessen - dvs. det forhold, at tillægsforsikringer tegnes i detailforretningen i tilknytning til køb af hovedproduktet - vurderes at spille en væsentlig rolle for de relevante juridiske problemstillinger, tillægsforsikringer rejser, beskrives selve salgsprocessen også relativt indgående.

I kapitel 3 analyseres de mulige juridiske fordele, som tillægsforsikringer giver sammenlignet med den beskyttelse mod funktionsfejl og andre mangler, som forbrugeren automatisk nyder efter den gældende køberetlige lovgivning og med dækningen i medfør af en eventuelt tegnet indboforsikring.

Kapitel 4 indeholder en redegørelse for den gældende forbrugerbeskyttelse ved køb af tillægsforsikringer, herunder den beskyttelse, der følger af købe- og aftalelovgivningen, markedsføringsloven, forsikringsaftale- og forsikringsformidlingsloven med videre.

I lyset af rapportens analyser indeholder kapitel 5 afslutningsvis udredernes retspolitiske overvejelser om den gældende forbrugerbeskyttelse ved køb af tillægsforsikringer og det mulige behov for lovgivningsmæssigt at styrke forbrugerbeskyttelsen. 



\section{Markedet for tillægsforsikringer}

\subsection{Markedets størrelse}

Ifølge Forbrugerstyrelsen (2002) tegner danske forbrugere en tillægsforsikring i ca. 1/3 af alle køb, hvor en tillægsforsikring udbydes. I faktiske tal svarer dette til mere end $1 / 2$ million tillægsforsikringer om året. I alt tegnes der i Danmark hvert år tillægsforsikringer for DKK 250-300 mio.

Nyere tal fra Norge og Sverige tegner et nogenlunde identisk billede af udbredelsen af tillægsforsikringer: Næsten 1/3 af alle købere af hårde hvidevarer og elektronik til hjemmet tegner tillægsforsikringer. I Norge medfører dette, at der i 2005 blev solgt ca. 600.000 tillægsforsikringer; en stigning på ca. 20 \% sammenlignet med året før - og en stigning på $600 \%$ siden 2002. I Sverige sælges ca. 2 mio. forsikringer pr. år, og den samlede omsætning voksede med $10 \%$ i $2004 .^{1}$

Der foreligger kun få oplysninger om Finland. Tal fra en af de største udbydere tyder på, at der i 2003 solgtes godt 200.000 tillægsforsikringer i Finland.

Der eksisterer efter det for udrederne oplyste ikke materiale om markedet for tillægsforsikringer på Island.

Det bemærkes, at det generelt er vanskeligt at opstille præcise tal for omsætningen af tillægsforsikringer, idet forretningerne af konkurrencehensyn er tilbageholdende med at give oplysninger.

For så vidt angår lande uden for Norden kan det oplyses, at en undersøgelse fra det engelske Competition Commission i 2003 viste, at der i Storbritannien i 2001 solgtes 18,5 mio. tillægsforsikringer (,extended warranties“) til en samlet værdi af ca. $£ 900$ mio. ${ }^{2}$ Også i vestlige lande uden for Europa, for eksempel Canada og USA, er der ifølge oplysninger på internettet sket en markant vækst i salget af tillægsforsikringer i forbindelse med elektronik- og andre forbrugerprodukter.

\subsection{Købernes profil}

En undersøgelse fra Sverige, foretaget i 2005, viser, at $37 \%$ af personer i aldersgruppen 15-29 år tegner en tillægsforsikring. For aldersgruppen

\footnotetext{
1 Jf. undersøgelse (2005) udarbejdet af Consumercontent for Gefle Dagblad.

2 Se om undersøgelsen uddybende http://www.competition-commission.gov.uk/rep_pub/ reports/2003/485xwars.htm\#-summary. Undersøgelsen viser i øvrigt, at tillægsforsikringer også i UK knytter sig til hårde hvidevarer og elektriske produkter, herunder computer- og teleprodukter.
} 
50-64 år er tallet 18 \%. Der tegnes flest tillægsforsikringer i store byer. Lidt flere kvinder end mænd tegner tillægsforsikringer. Der foreligger ikke systematiske undersøgelser fra de øvrige nordiske lande om købernes profil, men det er nærliggende at antage, at billedet er nogenlunde det samme.

\subsection{Produkter, hvortil der sælges tillægsforsikringer}

Tillægsforsikringer sælges først og fremmest i tilknytning til husholdningsprodukter og hårde hvidevarer (bl.a. vaskemaskiner, opvaskemaskiner, køle-/fryseskabe, komfurer, mikrobølgeovne, støvsugere, kaffemaskiner med videre) og de fleste former for forbrugerelektronik (radio/tvapparater og -monitorer (for eksempel fladskærme), videoapparater, HiFi-anlæg af alle slags, MP3- og CD-afspillere, computere, printere, scannere og andet computerudstyr, spilkonsoller, teleudstyr, kameraer/videokameraer og andet foto- og optageudstyr osv.).

I Sverige og Norge er det desuden udbredt at tilbyde tillægsforsikringer i forbindelse med salg af mobiltelefoner, selv billige mobiltelefoner. I Norge og Finland udbydes også tillægsforsikringer til briller. ${ }^{3}$ I Finland er der eksempler på, at der sælges tillægsforsikringer til cykler.

\subsection{Salgsprocessen}

Tillægsforsikringer er karakteriseret ved at være forsikringer, der alene vedrører ét bestemt produkt, og som sælges gennem detailleddet sammen med det produkt, som forsikringen knytter sig til. Salget af forsikringen sker af salgspersonalet i den forretning, hvor produktet købes. Den nødvendige information om tillægsforsikringen, dens dækningsomfang og varighed i forhold til reklamationsretten efter købeloven, forholdet til forbrugerens øvrige forsikringer osv., skal således gives af det ikke forsikringsuddannede salgspersonale.

Salget af forsikringen sker „på stedet“, altså i tidsmæssig tilknytning til købet af produktet. Inden forbrugeren forlader forretningen, er salgsprocessen vedrørende tillægsforsikringen med andre ord også overstået (hvad enten processen så er mundet ud i tegning af en tillægsforsikring eller ej).

Da forretningerne kun synes at samarbejde med ét forsikringsselskab, synes der typisk ikke for forbrugeren at være alternativer til den tilbudte tillægsforsikring (i modsætning til andre typer forsikringer, hvor forbrugeren normalt kan vælge mellem en række forskellige udbydere).

Betaling for tillægsforsikringen sker i forretningen samtidig med betalingen for det produkt, forsikringen vedrører. Præmien for forsikringen

\footnotetext{
${ }^{3}$ Jf. bilag 2.11 .
} 
betales separat ved siden af købesummen for det produkt, som forsikringen vedrører. I Norge ses dog eksempler på, at præmien for tillægsforsikringen er indeholdt i produktprisen.

Betalingen dækker hele forsikringens løbetid, der er fastsat på forhånd. I modsætning til andre forsikringer er der således ikke tale om løbende betalinger, der modsvarer en løbende fornyelse af forsikringen.

Den information om tillægsforsikringen, som salgspersonalet giver forbrugeren, og som forbrugeren træffer sit valg ud fra, er som oftest alene mundtlig. Der er ikke oplysninger, der tyder på, at ekspedienten som fast procedure sammen med forbrugeren gennemgår hvert enkelt forsikringsvilkår. Den omstændighed, at forsikringen tegnes i en ofte travl detailforretning, og at købet af forsikringen er sekundært i forhold til købet af selve produktet, gør det nærliggende at antage, at den samlede tid, der bruges på tillægsforsikringen - fra information til beslutning - er relativt beskeden.

Erhverves forsikringen direkte hos et forsikringsselskab, er der ikke tale om en tillægsforsikring i nærværende rapports forstand, men derimod om en indbo-, hus- eller lignende tingsforsikring, der knytter sig til en flerhed af løsøregenstande. Indboforsikringer o.lign. udbydes af mange forsikringsselskaber med en supplerende dækning mod uheld i hjemmet, der dækker alle løsøregenstande og således reelt har samme dækningsområde som mange tillægsforsikringer. Langt hovedparten af private husstande i de nordiske lande tegner en eller anden form for indboforsikring. Jævnfør om indboforsikringer uddybende nedenfor. Der er dog eksempler på, at forsikringsselskaber udbyder egentlige produktforsikringer i konkurrence med tillægsforsikringer, der sælges via detailhandlen. ${ }^{4}$

Så vidt ses, optræder detailleddet kun som formidler af tillægsforsikringen, idet forsikringsgiver er et bagvedliggende forsikringsselskab, som detailforretningen eller -kæden har indgået et samarbejde med. Der er enkelte eksempler på, at forsikringsselskabet er etableret af detailkæden selv alene med henblik på varetagelsen af de tillægsforsikringer, som forretningerne i detailkæden formidler.

Det kan undertiden være vanskeligt ud fra forretningens informationsmateriale at gennemskue, at forsikringsgiver er forskellig fra forretningen og hvem forsikringsgiver egentlig er.

Når tillægsforsikringer har fået en så markant udbredelse, som tilfældet er, beror det formentlig bl.a. på, at forretningerne i formidlingshonorar fra forsikringsselskabet modtager en relativt stor andel af forsikringssummen, som regel 30-50 \%, i visse tilfælde angiveligt endnu større. I en

\footnotetext{
${ }^{4}$ Det norske forsikringsselskab Gjensidige lancerede ultimo 2005 en ”kjøpsforsikring”, der dækker alle køb af bl.a. hårde hvidevarer, forbrugerelektronik og møbler, forudsat købsprisen overstiger 1000 NOK. Forsikringen gælder i indtil 3 år og indeholder en selvrisiko på 500 NOK. Ifølge forsikringsselskabet vil forsikringen - selv om den i mange henseender overlapper en eventuel indboforsikring - kunne have et selvstændigt dækningsområde, bl.a. derved, at kjøpsforsikringen også dækker uheld under transport og uheld uden for hjemmet. Forsikringen er tænkt som et konkurrerende produkt til individuelle tillægsforsikringer. Se nærmere http://www.gjensidige.no/forsikring/ internett/side?id=c373e9036a027b8f3778505054503030\&DocID=4526.
} 
tid, hvor avancerne generelt falder på de produkter, som tillægsforsikringerne oftest knytter sig til (hårde hvidevarer, forbrugerelektronik, fotoudstyr med videre), bliver salg af tillægsforsikringer herved et selvstændigt og meget attraktivt marked for detailleddet.

Hertil kommer, at salgspersonalet ekspedienterne i detailforretningerne ofte er helt eller delvist provisionslønnede, også med hensyn til salget af tillægsforsikringer. Dette øger selvsagt incitamentet for ekspedienterne til at sælge forsikringerne.

\subsection{Tillægsforsikringers indhold}

Tillægsforsikringer sælges under mange betegnelser. Her skal blot nævnes nogle typisk forekommende danske betegnelser:

Standardforsikring, basisforsikring, specialforsikring, Xtra-forsikring, tryghedsforsikring, plus-forsikring, luksusforsikring, eliteforsikring, serviceforsikring, totalforsikring

De forskellige typer af tillægsforsikringer kan systematisk inddeles i to overordnede kategorier, en standardforsikring (typisk betegnet basis- eller standardforsikring) og en udvidet forsikring (,special“, „ekstra“, „plus“, „total“ el. lign.). Mange udbydere sælger da også netop sådanne to varianter af deres tillægsforsikring.

Tillægsforsikringer - hvad enten der er tale om standard- eller udvidede tillægsforsikringer - indeholder mange små variationer fra produkt til produkt, udbyder til udbyder og land til land. Selv mange af de store, tværnordiske detailkæders tillægsforsikringer varierer i indhold fra land til land. Desuden kan én udbyders version af en standardforsikring reelt svare til en anden udbyders version af en udvidet tillægsforsikring. Og omvendt. Disse forhold gør det selvsagt vanskeligt at give et forholdsvis kortfattet „tværsnit“ over de udbudte tillægsforsikringer i Norden. Hovedlinierne i de mange forskellige tillægsforsikringer er dog så ens, at det er muligt at fremdrage en række fælles karakteristika. ${ }^{5}$

\subsubsection{Standardforsikringer}

Standardforsikringer er typisk karakteriseret ved følgende:

a) Dækningsomfang:

Tillægsforsikringers dækningsomfang varierer uhyre meget. Det samme gør sig gældende med hensyn til detaljeringsgraden i beskrivelsen af dækningsområdet. Nogle forsikringsbetingelser er endog særdeles kort-

\footnotetext{
${ }^{5}$ Det danske Forbrugerrådet har udarbejdet en sammenlignende opstilling over indholdet af tillægsforsikringer fra de største udbydere i Danmark, jf. http://www.forbrugerraadet.dk/penge/ produktforsikring/
} 
fattede (for eksempel således, at de kan optrykkes på bagsiden af kundens faktura). Hovedtendenserne synes dog at være følgende:

Tillægsforsikringer, herunder standardforsikringer, dækker i reglen fejl og mangler ved produktets funktionalitet, typisk formuleret som „funktionsfejl“, „mekanisk og elektrisk nedbrud“ eller lignende udtryk. En række af de undersøgte forsikringer understreger, at såfremt en funktionsfejl/-mangel er dækket af en garanti eller en reklamationsret efter lovgivningen, eller af en eksisterende indbo- eller anden type forsikring, dækker forsikringen ikke. Andre tager ikke et forbehold af denne karakter.

Mange standardforsikringer omfatter skade på genstanden som følge af en „pludselig og uforudset udefrakommende hændelse“ (i norske tillægsforsikringer ofte udtrykt som „plutselig og uforutsett hendelse“, „plutselig ytre årsak“ eller lignende; i svenske tillægsforsikringer som „plötslig och uförudsedd händelse“ o.lign). Det er imidlertid meget forskelligt, hvorvidt denne type hændelse er dækket eller ej, og flere udbydere dækker kun sådanne skader i deres udvidede tillægsforsikring - ikke i standardforsikringen.

Hvad der nærmere skal forstås ved udtrykket pludselige og uforudsete udefrakommende hændelser, kan ofte være svært at gennemskue. De færreste tillægsforsikringer indeholder nogen nærmere definition af begrebet. De fleste tillægsforsikringer synes imidlertid at anvende begrebet om fejl og mangler, som ikke relaterer sig til produktionsfejl eller andre fejl ved selve konstruktionen eller fremstillingen af genstanden, men som relaterer sig til skader ved genstanden, der er en følge af andre forhold, herunder navnlig personers uheldige omgang med genstanden, naturkræfter eller andet. ${ }^{6}$

Anskues udtrykket „funktionsfejl“ eller lignende som udtryk for det, der køberetligt betegnes „mangler/fel“, dvs. funktionssvigt med videre, som skyldes forhold indtruffet før tidspunktet for risikoens overgang, kan udtrykket „pludselig og uforudset udefrakommende hændelse“ formentlig retlig ses som refererende til funktionsfejl med videre, som skyldes forhold indtruffet efter risikoens overgang til køber. Idet det køberetlige mangelsbegreb - og dermed reklamationsretten efter købeloven - ikke dækker kvalitetssvigt pga. forhold indtruffet efter risikoovergangstidspunktet, har spørgsmålet om, hvorvidt tillægsforsikringen dækker efterfølgende funktionssvigt med videre, betydning for forsikringens reelle værdi i forhold til beskyttelsen efter de køberetlige regler. Jævnfør i det hele nærmere i kapitel 3.

Se til foreløbig illustration det danske Forsikringsankencevnets sag 63-652. En forbruger havde købt en tillægsforsikring i forbindelse med køb af en bærbar pc. Ved et uheld tabte forbrugeren pc'en da han ville bære den ned ad trappen i sin bolig. Pc'en blev ødelagt, og under henvisning til, at tillægsforsikringen dækkede „skader forårsaget af pludselige

\footnotetext{
${ }^{6}$ Se nærmere under 3.1.3.
} 
og uforudsete hændelser, som kan konstateres direkte på apparatet“, anmeldte forbrugeren skaden til forsikringsselskabet. Nævnet fandt, at der var tale om en pludselig og uforudset hændelse omfattet af tillægsforsikringen, og gav således forbrugeren medhold.

Se ligeledes det norske Forsikringsskadenemndas sag 5658. En forbruger købte en mobiltelefon med en tillægsforsikring. Parterne var uenige om, hvilken version af forsikringsbetingelserne, der var gældende for aftaleforholdet. Af den version af betingelserne, som nævnet lagde til grund, fremgik, at forsikringen bl.a. dækkede skader som følge af „uforudsete hændelser“. Forsikringen nævnte positivt fugtskader på mobiltelefoner som et eksempel på uforudsete hændelser. Forbrugerens mobiltelefon gik i stykker på grund af fugtskade. Nævnet fandt, at skaden var omfattet af forsikringen.

Se tilsvarende det norske Forsikringsskadenemndas sag 4028. En blot en måned gammel mobiltelefon gik i stykker som følge af en vandskade. Vandskaden viste sig at skyldes, at den sikrede havde haft mobiltelefonen liggende i en taske med en læk vandflaske. Forsikringsselskabet bestred, at der var tale om en skade, der var dækningsberettiget efter den tegnede tillægsforsikring. Nævnet fandt imidlertid, at skaden var omfattet af begrebet „pludselig ydre årsag“ og gav derfor den sikrede medhold. ${ }^{7}$

Standardtillægsforsikringers kerneområde er som omtalt funktionsfejl, nedbrud o.lign. Det er derfor ikke almindeligt, at forsikringen dækker tyveri. Derimod omfatter mange af de udvidede tillægsforsikringer også tyveri, jf. nedenfor. ${ }^{8}$ Ofte fremgår det udtrykkeligt af standard-tillægsforsikringen, at den ikke dækker tyveri, eller kun dækker subsidiært, såfremt tyveriet ikke allerede er dækket af forsikringstagers eksisterende forsikringer. En stor svensk udbyder af tillægsforsikringer anvender den særlige variant, at tillægsforsikringen dækker tyveri „, i den forstand, at forsikringen reducerer indboforsikringens selvrisiko“. ${ }^{9}$ Vilkåret må formentlig modsætningsvis forstås således, at såfremt forbrugeren ikke har tegnet en indboforsikring, eller har tegnet en indboforsikring uden selvrisiko, dækker tillægsforsikringen ikke ved tyveri.

Undertiden er også tilbehør til elektroniske produkter såsom fjernbetjening, genopladelige batterier med videre, udtrykkeligt omfattet af forsikringen. Visse forsikringer er dog tavse om dette spørgsmål, ligesom atter andre positivt undtager sådant tilbehør fra forsikringsdækningen.

En række forsikringer dækker også transportomkostninger forbundet med reparation, dog som regel forudsat, at der er tale om et i fysisk henseende større produkt (større tv, større stationære anlæg eller lignende).

\footnotetext{
${ }^{7}$ Sml. det svenske Allmänna reklamationsnämndens sag 2004-8426, hvor en fugtskade på en PC ikke fandt at være opstået som følge af et uheld og derfor efter nævnets opfattelse ikke var omfattet af et tegnet tillægsforsikring.

${ }^{8}$ Se om fortolkning af begrebet "tyveri” i forhold til "indbrudstyveri” det danske Forsikringsankencevnets sag. 62.786.

${ }^{9}$ Jf. bilag 2.3, pkt. 2 .
} 
De fleste standard-tillægsforsikringer dækker udtrykkeligt ikke almindelig slitage eller almindelig vedligeholdelse (rensning med videre). Heller ikke følgeskader dækkes.

De fleste tillægsforsikringer er tavse om deres geografiske dækningsområde. Enkelte præciserer dog, at forsikringen gælder i hele verden. ${ }^{10}$

I relation til afgrænsningen mellem på den ene side tillægsforsikringens dækningsområde, og på den anden side dækningen efter en eventuel indboforsikring, købelovens regler og/eller en eventuel køberetlig garanti, fastslår mange - såvel standard- som udvidede - tillægsforsikringer, at tillægsforsikringen ikke gælder, hvis skaden dækkes af en indboforsikring eller er omfattet af reklamationsretten eller en udstedt producent- eller forhandlergaranti. ${ }^{11}$

b) Dækningsperiode og ikrafttræden:

Også sikringsperioden varierer, både fra forsikring til forsikring og fra produkt til produkt inden for den enkelte forsikring. Det mest almindelige synes at være, at sikringsperioden for en standard-tillægsforsikring er 3 år. I visse tilfælde er den dog længere, for eksempel 4 eller 5 år, for lidt dyrere produkter såsom større tv-apparater, fladskærme o.lign. For enkelte produkters vedkommende, navnlig mobiltelefoner, kan sikringsperioden være kortere, typisk 2 år. I så fald er sikringsperioden ikke længere end reklamationsfristen efter den danske købelov og kortere end reklamationsfristen i de øvrige nordiske lande. ${ }^{12}$

Det forhold, at forsikringstiden ikke er længere end den lovpligtige reklamationsfrist efter køberetlige regler, forklares undertiden med henvisning til, at tegning af forsikringen indebærer, at bevisbyrden er vendt om i hele forsikringstiden - og ikke kun i de første 6 måneder, således som det kræves efter forbrugerkøbsdirektivet. ${ }^{13}$

Forsikringstiden løber i almindelighed straks fra aftalens indgåelse. Ved visse danske tillægsforsikringer reflekterer forsikringstiden nøje den køberetlige reklamationsfrist, således at forsikringen enten først træder i kraft efter udløbet af den køberetlige 6 måneders formodningsperiode (inden for hvilken udbyderen bærer bevisbyrden for, at en påvist kvalitetsafvigelse ikke udgør en køberetlig mangel), eller først 2 år efter købsdatoen (svarende til udløbet af den absolutte reklamationsperioden efter den danske købelov). ${ }^{14}$

c) Erstatningssum/afskrivning/selvrisiko:

Formuleringen af de fleste tillægsforsikringer må forstås således, at den erstatning, forbrugeren er berettiget til, såfremt tillægsforsikringen udnyttes, er produktets genanskaffelsesværdi på skadestidspunktet, dog mak-

\footnotetext{
${ }^{10} \mathrm{Jf}$. fx bilag 2.20 , pkt. 3.

${ }^{11}$ Jf. fx bilag 2.3 og 2.16 og bilag 2.10 .

${ }^{12}$ Se nærmere under 3.2.1.

${ }^{13}$ Se fx bilag 2.15 .

${ }^{14}$ Jf. bilag 2.4, pkt. 1, og bilag 2.8 .
} 
simeret til den oprindelige købspris. Herved er tillægsforsikringer i udgangspunktet i overensstemmelse med det almindelige forsikringsretlige princip om, at erstatningen opgøres til den forsikrede genstands genanskaffelsesværdi (dvs. det beløb, det vil koste at genanskaffe en tilsvarende ting, med rimeligt fradrag for værdiforringelse som følge af alder, brug, nedsat anvendelighed eller andre omstændigheder). ${ }^{15}$ Ligeledes i overensstemmelse med det almindelige forsikringsretlige princip om, at forsikringstager ikke må beriges ved forsikringen, ${ }^{16}$ danner købesummen maksimum for erstatningen.

En række tillægsforsikringer er imidlertid ikke formuleret klart på dette punkt. Formuleringer som ,en kontanterstatning modsvarende prisen for et nyt, tilsvarende apparat" kan give forbrugeren forventning om, at erstatningen er den oprindelige købspris - uden fradrag for almindelig slitage, alder med videre. Misforståelsen opstår navnlig ved udvidede tillægsforsikringer, hvor den højere pris for forsikringen bl.a. begrundes med, at der i erstatningssummen ikke sker af- eller nedskrivning i forhold til købsprisen. Dette forstår forbrugerne antagelig ofte som et vilkår om, at erstatningssummen altid vil være lig købesummen. Forbrugeren får derfor en overraskelse, når det senere viser sig, at erstatningen opgøres efter genanskaffelsesprincippet, dvs. med almindelig fradrag for alder, slitage med videre. Problemstillingen, der har givet anledning til sager for Forsikringsankenævnet, behandles uddybende nedenfor under 3.3 .2 og 4.7.2.

Eventuelle yderligere tabsposter, indirekte tab med videre knyttet til forsikringsbegivenheden dækkes i udgangspunktet ikke. Dette svarer til almindelige forsikringsretlige principper.

Mange standard-tillægsforsikringer indeholder vilkår om, at erstatningssummen afskrives eller nedskrives løbende, ofte med 20 \% pr. år. I visse tilfælde begynder afskrivningen dog først ved udløbet af et fast tidsrum, for eksempel et tidsrum svarende til den køberetlige reklamationsfrist. ${ }^{17}$ Det er ligeledes almindeligt, at standardforsikringerne indeholder vilkår om selvrisiko, dvs. at erstatning kun betales over et vist minimumsbeløb, der ofte ligger i størrelsesordenen 100-300 kr. ${ }^{18}$

\section{d) Opsigelse og ophør}

Det er ikke sædvanligt, at en tillægsforsikring indeholder vilkår om opsigelse eller om forlængelse efter udløb af den periode, forbrugeren har betalt for ved købsaftalens indgåelse. Forsikringen dækker således i ud-

\footnotetext{
${ }^{15} \mathrm{Jf}$. for dansk rets vedkommende forsikringsaftalelovens (FAL) § 37, og uddybende nedenfor i kapitel 3 og 4 .

${ }^{16} \mathrm{Jf}$. fx dansk FAL $\S 39$.

${ }^{17}$ Se fx bilag 2.2 og 2.5 .

${ }^{18}$ Nogle udbydere opererer dog med væsentlig højere selvrisiko, jf. fx bilag 2.7 (490 DKK) og 2.9 (10 \% af skadebeløbet, ved bærbart udstyr dog minimum 500 DKK).
} 
gangspunktet i én bestemt periode. ${ }^{19}$ Ofte ophører tillægsforsikringen efter vilkårene automatisk ved totalskade eller tyveri, hvor der ikke er mulighed for at reparere genstanden, og hvor erstatningssummen derfor kommer til udbetaling, eller genstanden erstattes med en tilsvarende genstand. I sådanne situationer, hvor forsikringen er udnyttet „fuldt ud“, bortfalder den således automatisk, selv om forsikringsperioden formelt set ikke er udløbet. Dette svarer til det almindelige forsikringsretlige princip (der synes at anerkendes i alle nordiske lande) om, at en forsikring automatisk bortfalder, og forsikringstiden dermed ophører, når den interesse, der er tegnet forsikring for, falder bort.

Ophører forsikringen som følge af, at den forsikrede interesse bortfalder ved tyveri eller totalskade), er der efter vilkårene ofte ingen mulighed for at få tilbagebetalt dele af forsikringspræmien. Nogle enkelte tillægsforsikringer yder dog forholdsmæssig tilbagebetaling ved totalskade eller tyveri.

Se i det hele nærmere under 4.6.

e) Overdragelse

Muligheden for at overdrage forsikringen (sammen med det forsikrede produkt) er meget forskellig fra tillægsforsikring til tillægsforsikring. Nogle forsikringer indeholder en sådan ret, ${ }^{20}$ andre gør retten betinget af forretningens samtykke, og atter andre indeholder ingen overdragelsesret eller udtaler sig ikke om spørgsmålet. Se nærmere under 4.7.1.

\section{f) Sammenfatning:}

Det samlede billede, der tegner sig af en „gennemsnitlig“ standardtillægsforsikring er, at denne i relation til dækningsomfang sjældent adskiller sig væsentligt fra de fejl og mangler, over for hvilke forbrugeren kan reklamere efter købelovens reklamationsregel. Forskellen ligger typisk i, at tillægsforsikringen har en lidt længere dækningsperiode, som regel 3-5 år, end reklamationsfristen efter de fleste nordiske landes lovgivning. I nogle tilfælde dækker tillægsforsikringen dog skader eller andre forsikringsbegivenheder, som reklamationsretten ved mangler ikke dækker. Til gengæld er der som regel andre vilkår i tillægsforsikringen, for eksempel vedrørende afskrivning og selvrisiko, som i realiteten giver forbrugeren ringere dækning end de køberetlige reklamationsregler. Det juridiske forhold mellem tillægsforsikringer og de køberetlige reklamationsregler gennemgås nedenfor i kap. 3.

\footnotetext{
${ }^{19}$ Hvorved tillægsforsikringer adskiller sig fra de fleste andre typer forsikringer, der tegnes ”på opsigelse”, dvs. som en løbende aftale, der automatisk forlænges, typisk for et år ad gangen, hvis den ikke opsiges med en bestemt frist.

${ }^{20}$ Jf. bilag 2.17-2.19.
} 


\subsubsection{Udvidede tillagsforsikringer}

De udvidede tillægsforsikringer giver i forhold til standardtillægsforsikringerne forbrugeren bedre vilkår på forskellige punkter (hvilket modsvarer den højere pris). Også her er der betydelige forskelle fra forsikring til forsikring.

\section{a) Dækningsomfang:}

Som nævnt er der så stor forskel mellem de enkelte tillægsforsikringer, at det er vanskeligt at tegne et entydigt billede af, hvad der er kendetegnende for en standard- henholdsvis udvidet tillægsforsikring. ${ }^{21}$ Visse typiske forskelle kan dog fremdrages. I forhold til en standardforsikring dækkes således ofte et eller flere af de punkter, som standardforsikringen ikke dækker, for eksempel „pludselige og uforudsete udefrakommende hændelser“, tyveri, slitage, transport til/fra værksted ved større forbrugsgenstande eller visse følgeskader. ${ }^{22}$

b) Dækningsperiode:

Hvor varigheden af forsikringen som nævnt for standardforsikringers vedkommende typisk er 3-4 år, er varigheden i mange tilfælde lidt længere ved de udvidede forsikringer, for eksempel 5-6 år.

c) Erstatningssum/afskrivning/selvrisiko:

Ved mange udvidede tillægsforsikringer sker der ingen eller kun en beskeden løbende afskrivning af erstatningssummen, ligesom der ingen eller kun en meget lille selvrisiko er. Nogle udvidede tillægsforsikringer yder endvidere dækning for visse følgeskader (for eksempel tøj ødelagt under vask i defekt vaskemaskine), således at erstatningssummen i princippet kan blive højere end den af forbrugeren erlagte købesum (der normalt danner maksimum for erstatningen, jf. det ovenfor omtalte forsikringsretlige berigelsesforbud).

Som det er tilfældet ved en række standardtillægsforsikringer, følger det af nogle udvidede tillægsforsikringer, at der ikke ydes kontanterstatning. ${ }^{23}$ Forbrugeren er således henvist til at modtage et erstatningsprodukt af tilsvarende kvalitet.

Som omtalt ovenfor kan udvidede tillægsforsikringers affattelse i relation til erstatningsopgørelsen give anledning til fortolkningsproblemer i praksis, jf. nærmere under 4.7.2.

d) Opsigelse:

Her gælder sædvanligvis det samme som ved standardforsikringerne.

\footnotetext{
${ }^{21}$ Som eksempel på en tillægsforsikring, der - modsat de fleste øvrige udvidede tillægsforsikringer - slet ikke dækker tyveri, se bilag 2.13.

${ }^{22}$ Se eksempel på, at visse følgeskader dækkes, bilag 2.20, pkt. 5.

${ }^{23}$ Se eksempelvis bilag 2.13 .
} 
e) Mulighed for overdragelse:

Her gælder sædvanligvis det samme som ved standardforsikringerne.

f) Sammenfatning:

Samlet kan det om de udvidede tillægsforsikringer siges, at de set fra forbrugerens side er mere fordelagtige end standardforsikringerne, idet de har et større dækningsomfang, længere forsikringstid, mindre eller ingen selvrisiko, mindre eller ingen løbende nedskrivning af anskaffelsesværdien eller andre fordele. Den øgede dækning modsvares dog naturligvis af en højere pris for udvidede tillægsforsikringer, jf. straks nedenfor.

\subsection{Pris}

Prisen for en tillægsforsikring ligger fra ca. DKK 300 for de billigste til omkring DKK 2000 for de dyreste, afhængig af type og pris på det produkt, tillægsforsikringen knytter sig til, samt forsikringens dækningsomfang. Typisk ligger forsikringen i prisområdet 500-1500 DKK. De udvidede tillægsforsikringer er i sagens natur dyrere end standardtillægsforsikringerne. I de fleste tilfælde udgør prisen for tillægsforsikringen 10-20 \% af prisen på det forsikrede produkt.

Der er en klar tendens til, at jo billigere produktet er, des dyrere er tillægsforsikringen relativt set - og omvendt. Ved meget dyre produkter, for eksempel fladskærms-tv til omkring DKK 20.000, er tillægsforsikringen ofte ikke meget dyrere end ved produkter, der kun koster det halve, hvilket betyder, at forsikringen „kun“ koster ca. 5-10\% af produktets pris. Dette synes at tyde på, at der en absolut „overgrænse“ for, hvor høj prisen på en tillægsforsikring kan være - uanset prisen på det produkt, forsikringen vedrører.

\subsection{Udbydere}

a) Detailleddet

Tillægsforsikringer er som tidligere nævnt mest udbredt i brancherne for hårde hvidevarer, herunder husholdningsprodukter, og forbrugerelektronik, bl.a. AV-, tele-, medie- og fotoapparatur og -udstyr. Men også i andre brancher, for eksempel brilleforretninger, forekommer tillægsforsikringer.

Tillægsforsikringer synes at være mest udbredt blandt større detailkæder, herunder navnlig dem, der breder sig over de fleste former for hårde hvidevarer og/eller forbrugerelektronik. For Danmarks vedkommende kan nævnes kæder som Fona/Fredgaard, El-giganten, Electric City, Elsalg, Merlin, Expert, 2tal, ComputerCity samt de største dagligvarekæder, 
herunder Dansk Supermarked og COOP. For Sveriges vedkommende kan nævnes ONOFF, SIBA og Elkøp; for Norges for eksempel Expert.

Flere af de nævnte kæder er tvær-nordiske og opererer således i flere eller alle nordiske lande. Dette gælder for eksempel svenske Elkjøp, der er Nordens største udbyder af forbrugerelektronik og elektriske husholdningsapparater, og som via ejerskabet til ikke blot Elkjøp-kæden selv, men også andre store kæder som El-Giganten, Lefdal (Norge) og Gigantti (Finland), er aktiv i flere eller samtlige nordiske lande. Ligeledes indtager norske Expert gennem ejerskabet af kæderne Expert, 2tal og Punkt1 en væsentlig andel af ikke blot det norske, men også det danske marked for forbrugerelektronik og elektriske husholdningsprodukter, ligesom selskabet også er meget aktivt på det svenske marked.

Det forhold, at de største kæder er tvær-nordiske, og i øvrigt bruger de samme bagvedliggende forsikringsselskaber (navnlig det svenske SOLID Försäkring $\mathrm{AB}$ ), bidrager til, at tillægsforsikringer - på trods af de mange individuelle særpræg (jf. ovenfor) - dog kan siges at have en række ensartede kendetegn på tværs af de nordiske lande.

Også mange mindre kæder og enkeltstående forretninger tilbyder tillægsforsikringer.

b) Bagvedliggende forsikringsselskaber

De bagvedliggende forsikringsselskaber, med hvem forbrugeren - via detailforretningen - indgår forsikringsaftalen, er typisk de samme på tværs af de nordiske lande. Dette tyder på, at kredsen af forsikringsselskaber, der udbyder tillægsforsikringer i samarbejde med detailleddet, er forholdsvis beskeden. De bagvedliggende forsikringsselskaber omfatter navnlig en række svenske selskaber (for eksempel Solid Försäkringer $\mathrm{AB}$, Moderna Försäkringer Sak $\mathrm{AB}^{24}$ og SAFE Internationale Försäkring $A B$ ), britiske (navnlig Bankers Insurance og Inter Hannover Ldt.), og tyske (for eksempel Axa Versicherung AG). Ofte er der således tale om, at forbrugeren indgår forsikringsaftalen med et udenlandsk forsikringsselskab. Har forsikringsselskabet en filial i forbrugerens hjemland, indgås aftalen ofte via denne filial. I andre tilfælde indgås forsikringsaftalen gennem en forsikringsmæglervirksomhed i forbrugerens hjemland.

En meget stor del af de ca. $1 / 2$ million danske tillægsforsikringer, der tegnes hvert år, formidles således - ifølge tal fra 2002/2003 - gennem forsikringsmæglerfirmaerne Inter Assurance A/S, Tryghed.net og Assurant Services Danmark (sidstnævnte er en del af Assurant Group Ltd. (UK), der igen er del af Bankers Insurance Company Ltd. (UK)). Ligeledes formidler Tryghed.net forsikringer for det svenske SAFE Internationale Forsäkräing AB).

Der er dog også enkelte større danske forsikringsselskaber, der tegner tillægsforsikringer, for eksempel TRYG. Inden for computerbranchen

\footnotetext{
${ }^{24}$ Moderna Försäkringer er et datterselskab til Invik \& Co., som igen er en del af Kinnevikgruppen.
} 
synes det danske forsikringsselskab edbForsikring.dk (USG Danmark $\mathrm{A} / \mathrm{S}$ ) at være dominerende

\subsection{Skades- og udbetalingsfrekvens}

Ifølge Forbrugerstyrelsen viser oplysninger (fra 2003) fra de danske forsikringsmæglerfirmaer, der udbyder størsteparten af tillægsforsikringer i Danmark (Assurant Services Danmark A/S, Inter Assurance A/S og Tryghed.net), at forsikringerne bliver udnyttet i 30-40 \% af de situationer, hvor en forsikring er tegnet. Dette bekræftes af en udsendelse om tillægsforsikringer i DR’s TV-magasinprogram „Kontant“ fra september 2005, hvor direktøren for El-Giganten nævnte en udbetalingsfrekvens på $37 \%$.

De produkter, hvor tillægsforsikringer oftest udnyttes, er fjernsyn i de højeste prisklasser, vaskemaskiner/tørretumblere og opvaskemaskiner. De produkter, der mest sjældent udløser en tilkøbt tillægsforsikring, er komfurer, køle- og fryseskabe samt musikanlæg i de laveste prisklasser.

I langt de fleste tilfælde er det en fabrikationsfejl eller anden indbygget svaghed ved produktet, der udløser forsikringen. I godt halvdelen af tilfældene er den fejl eller mangel, der påberåbes, opstået efter udløbet af den 2-årige reklamationsperiode ifølge den danske købelov.

Heroverfor står imidlertid - for så vidt angår tv-apparater - en opgørelse fra $2003^{25}$ over reparationer af tv-apparater. Opgørelsen viser, at omkring $90 \%$ af den type fejl og mangler, der dækkes af tillægsforsikringer, opstår inden for de første 2 år efter købet, dvs. inden for den reklamationsperiode, der følger af den danske købelov.

\subsection{Særligt om ligheder og forskelle mellem de nordiske lande}

De oplysninger, som udrederne er i besiddelse af, tyder på, at det er de samme overordnede tendenser, der gør sig gældende på markedet for tillægsforsikringer i hele Norden. Dette er i og for sig ikke overraskende, eftersom de største formidlere af tillægsforsikringer - de store detailhandelskæder inden for hårde hvidevarer og forbrugerelektronik - opererer på tværs af de nordiske lande og anvender de samme bagvedliggende forsikringsselskaber.

Konklusionen - at det er de samme overordnede tendenser, der gør sig gældende i de respektive nordiske lande - er mest sikker når man sammenligner Danmark, Norge og Sverige. Det skyldes, at der i disse lande er flest tilgængelige oplysninger om forholdene angående tillægsforsik-

\footnotetext{
${ }^{25}$ Opgørelse foretaget af Brancheforeningen for ForbrugerElektronik (ifølge oplysninger indhentet af Forbrugerinformationen, som refereret på Forbrugerstyrelsens hjemmeside).
} 
ringer. Der er kun få tilgængelige oplysninger om forholdene i Finland og Island, hvilket gør det svært at drage sikre konklusioner.

Uanset de sparsomme oplysninger om forholdene i Finland og Island synes det på baggrund af de indhentede oplysninger at kunne lægges til grund som en markant forskel mellem på den ene side Danmark, Norge og Sverige, og på den anden side Finland og Island, at markedet for tillægsforsikringer er væsentligt mindre i Finland og Island end i de øvrige nordiske lande. Præcist, hvor stort markedet er i disse to lande, foreligger der dog ikke efter det for udrederne oplyste konkrete tal for.

En anden forskel mellem Danmark, Norge og Sverige på den ene side, og Finland og Island på den anden, synes efter det oplyste at være, at meget få forbrugere i Finland og Island har klaget over tillægsforsikringer til offentlige myndigheder, administrative klageorganer, forbrugerorganisationer eller domstolene. Derfor har der heller ikke fra de ansvarlige myndigheders side været anledning til at igangsætte formelle undersøgelser vedrørende tillægsforsikringer.

Fraværet af forbrugerklager kan selvsagt være en naturlig følge af, at salget af tillægsforsikringer som nævnt er væsentlig mindre i Finland og Island, og er således ikke ensbetydende med, at tillægsforsikringer ikke giver anledning til problemer i disse lande. Fra Finland oplyses således bl.a., at de overordnede problemer, der kan spores i Danmark, Norge og Sverige, herunder vedrørende uklare forsikringsvilkår og usikkerhed omkring forsikringens forhold til købelovens mangelsregler og en eventuel garanti, også gør sig gældende i Finland. Udrederne har imidlertid ikke tilstrækkeligt med oplysninger til at belyse dette nærmere.

Bortset fra de nævnte forskelle synes det et være de samme tendenser, der gør sig gældende i Finland og Island som i de øvrige lande. Salget af tillægsforsikringer sker typisk gennem filialer af de samme tværnordiske detailhandelskæder, der også opererer i de øvrige nordiske lande. Det er derfor typisk også de samme bagvedliggende forsikringsselskaber, der er forbrugerens kontraktspart i Finland og Island, som i de øvrige nordiske lande. Prismæssigt synes tillægsforsikringer i Finland og Island at ligge i det samme leje som i de øvrige nordiske lande.

Også i relation til selve udformningen af tillægsforsikringer synes Finland og Island at ligge tæt op ad de øvrige nordiske lande (hvilket igen kan forklares med, at det i al væsentlighed er de samme detailkæder som i de øvrige lande, der formidler forsikringerne, og de samme bagvedliggende forsikringsselskaber). Tillægsforsikringer anvendes således navnlig i forbindelse med hårde hvidevarer og elektronikprodukter. Dækningsområdet - og undtagelserne hertil - er i store træk identisk, ligesom forsikringerne ofte opererer med selvrisiko, afskrivning, bortfald af forsikringen ved erstatningens udbetaling samt de øvrige ovenfor beskrevne vilkår, der gælder for en typisk tillægsforsikring.

Som nævnt er forholdene meget identiske for så vidt angår Danmark, Norge og Sverige. Der er dog også forskelle. Det forhold, at den køberet- 
lige absolutte reklamationsfrist angående mangler er forskellig i de tre lande, medfører således visse forskelle i affattelsen af tillægsforsikringerne landene imellem. For Danmarks vedkommende, hvor reklamationsfristen er 2 år, vil en tillægsforsikring, der dækker i for eksempel 3 år, alt andet lige give forbrugeren en bedre retsstilling end i Norge, hvor reklamationsfristen for mange af de produkter, hvortil der typisk sælges tillægsforsikringer, er 5 år. Det betyder, at forbrugerfordelene i Norge må „hentes hjem“ på andre områder, for eksempel i form af lidt bedre dækningsvilkår.

\subsection{Sammenfatning vedrørende markedet for tillægsforsikringer}

- Der er tale om et i økonomiske henseende ganske betydeligt marked

- Tillægsforsikringer bruges fortrinsvis ved salg af elektronikprodukter og hårde hvidevarer. Udbyderne er fortrinsvis større butikskæder, hvoraf mange opererer i flere nordiske lande.

- Tillægsforsikringer tegnes i detailforretningen i i umiddelbar forbindelse med købet af hovedproduktet. Forretningen er således formidler (fuldmægtig) for et bagvedliggende forsikringsselskab, med hvem aftalen indgås

- Detailforretningen modtager en ofte betydelig provision af forsikringsselskabet for salg af tillægsforsikringer

- Tillægsforsikringers indhold og dækningsomfang varierer meget, navnlig afhængigt af, om der er tale om en „standard-“ eller en „udvidet“ tillægsforsikring. Hvor førstnævnte ofte kun i beskedent omfang giver en beskyttelse, der rækker ud over den lovbestemte beskyttelse ved fejl og mangler, giver de fleste udvidede tillægsforsikringer en udvidet beskyttelse. Denne udvidede beskyttelse er dog relativ bekostelig for forbrugeren, navnlig hvis denne i kraft af en indboforsikring allerede har sikret sig imod nogle af de begivenheder, som ikke omfattes af de køberetlige regler. 



\section{Forbrugerfordele ved tillægsforsikring}

Tillægsforsikringer ved køb af forbrugsgoder har bl.a. til formål at befri forbrugeren for nogle af de økonomiske risici, køberen ellers ville have. Der er således tale om, at forbrugeren mod betaling opnår en vis højere grad af økonomisk tryghed, end han/hun ellers ville have haft som køber. Også uden en tillægsforsikring er forbrugeren imidlertid befriet for en række af de økonomiske risici, der er forbundet med anskaffelsen af det pågældende gode.

For det første indebærer de køberetlige regler, at visse kvalitetsafvigelser ved salgsgenstanden udgør misligholdelse (kontraktbrud) af købsaftalen eller af eventuelle særlige garantitilsagn, og som sådanne i kraft af kontraktretlige regler giver forbrugeren nærmere angivne økonomiske beføjelser over for sælgeren og/eller garantigiver.

For det andet er salgsgenstanden i praksis ofte omfattet af en af forbrugeren tegnet indboforsikring/hemförsäkring med videre, som mod betaling af forsikringspræmie befrier forbrugeren for forskellige nærmere aftalte risici.

Det, som forbrugeren betaler for ved køb af en tillægsforsikring, er således forsikringsselskabets overtagelse af sådanne risici, som ikke er dækket af køberetlige regler om mangler/fel eller, eventuelle særlige produktgarantier og heller ikke af en af forbrugeren tegnet indboforsikring med videre.

Med henblik på at fastslå, hvad forbrugeren får for pengene ved køb af en tillægsforsikring i forbindelse med varekøb, sammenlignes i det følgende tillægsforsikringernes typiske dækning med den dækning, der i praksis typisk følger af køberetlige regler om mangler/fel, af særlige garantitilsagn og af indboforsikringer med videre.

\subsection{Dækningsområdet}

\subsubsection{Tillcegsforsikringsbegivenheden ctr. køberetlige regler om mangler}

Tillægsforsikringers typiske dækningsområde er funktionsfejl, mekaniske og elektriske nedbrud og lignende, dvs. fejl ved selve tingen, der forringer dennes anvendelighed. ${ }^{26}$

\footnotetext{
${ }^{26}$ Se fx bilag 2.1, bilag 2.2, bilag 2.3 og bilag 2.5 samt oversigten i afsnit 2.
} 
Salgsgenstandens tekniske kvalitet (funktion, driftsikkerhed, holdbarhed med videre) er også det centrale i henhold til køberetlige regler om mangler og garantier.

Alment udtrykt kan forbrugerkøberen efter køberetlige regler stille krav om, at salgsgenstandens kvalitet lever op til, hvad der følger af aftalen eller med rette er forudsat af køberen. Heraf følger, at der foreligger misligholdelse (kontraktsbrud) i form af mangler (fel), såfremt varen ikke har den aftalte kvalitet eller den kvalitet, der normalt forventes af en lignende vare. ${ }^{27}$

I den foreliggende sammenhæng, hvor der er spørgsmål om at fastslå, i hvilket omfang forbrugerkøbere i kraft af en tillægsforsikring opnår større tryghed end den, der følger af køberetlige regler, samler interessen for de køberetlige regler sig i første række om det generelle mangelsbegreb, dvs. de kvalitetskrav, som forbrugeren i fravær af særlige individuelle omstændigheder i det konkrete aftaleforhold har ret til at stille. De forhold, som på grund af omstændighederne i det enkelte tilfælde kan begrunde, at den enkelte køber kan stille mindre eller større krav til salgsgenstandens kvalitet end køberne i almindelighed ${ }^{28}$ (dvs. det individuelle mangelsbegreb), kan vanskeligt bruges som målestok ved en sammenligning med den risikoovertagelse, der finder sted ved en standardiseret tillægsforsikring, hvis dækningsomfang jo i praksis er fastsat uafhængigt af de konkrete forhold i det enkelte kontraktforhold. ${ }^{29}$

På denne baggrund kan det køberetlige sammenligningsgrundlag for tillægsforsikringernes dækningsområde beskrives forholdsvis enkelt med henvisning til det generelle mangelsbegreb. I overensstemmelse hermed skal varen være egnet til de formål, som varer af den pågældende type sædvanligvis anvendes til, og have den beskaffenhed og brugbarhed, der er sædvanlig for varer af samme type, og som forbrugeren med rimelighed kan forvente under hensyntagen til deres art og i givet fald de oplysninger om deres konkrete egenskaber, der er afgivet offentligt om dem af sælgeren, producenten eller dennes repræsentant, navnlig i reklamer eller gennem mærkning, jf. herved forbrugerkøbsdirektivets art. 2, stk. 2, litra $\operatorname{cog} \mathrm{d}$.

\footnotetext{
${ }^{27}$ Se nærmere dansk købelov (KBL) §§ 75a-76, finsk konsumentskyddslag (KSL) 5.kap. §§ 1214, islandsk lov om forbrugerkøb (FKL) §§ 15-17, norsk forbrukerkjøpslov (FKPL) §§ 15-17 og svensk konsumentköpslag (KKPL) §§ 16-19, som alle er resultatet af EU-minimumsharmonisering i henhold til forbrugerkøbsdirektivet (99/44/EF).

${ }^{28}$ Fx kan sælgerens ”accept” af forbrugerens ønske om, at salgsgenstanden skal kunne anvendes til et specielt formål, begrunde, at en ellers mangelfri varen anses for mangelfuld, hvis den ikke er egnet til det specielle formål, jf. forbrugerkøbsdirektivets art 2, stk. 2, litra b. Den anførte sondring mellem det "generelle" og det "individuelle" mangelsbegreb synes i øvrigt, i hvert fald delvis, at være sammenfaldende med den i nordisk teori traditionelle skelnen mellem en "abstrakt" og en "konkret" mangelsbedømmelse, se herom Viggo Hagstrøm: Kjøpsrett (2005) s. 65.

${ }^{29}$ Noget andet er, at sælgeren i kraft af almindelig principper om loyal oplysningspligt må oplyse forbrugeren om sådanne særlige forhold, som bevirker, at tillægsforsikringen ikke har eller kun har begrænset værdi for den pågældende. Se til illustration det danske Forbrugerklagenævnets sager 1997-4031/7-512 og 1997-4031/7-597, der begge er nærmere omtalt nedenfor under 4.3.
} 
Tillægsgarantiernes dækning af funktionsfejl med videre går ikke videre end den „dækning“, der efter køberetlige regler følger af det omtalte generelle mangelsbegreb. ${ }^{30}$ Tværtimod er dækningen snævrere. Det skyldes for det første, at ikke enhver køberetlig mangel har betydning for varens funktion, men kan berøre andre kvalitetsaspekter, for eksempel varens udseende. Desuden undtager tillægsforsikringsvilkårene for det andet typisk „forbrugsartikler“ med videre og funktionsfejl, der skyldes for eksempel fejlinstallation og transportskader på grund af uhensigtsmæssig indpakning, fra forsikringsdækningen, uden hensyn til at disse forhold efter omstændighederne kan udgøre en køberetlig mangel. ${ }^{31}$

Endvidere er typisk også „slitageskader“ undtaget fra dækningen, uanset at slitageskader, der under normal anvendelse indtræffer inden for en kortere årrække vel typisk vidner om, at et „,varigt“ forbrugsgode som for eksempel en vaskemaskine, et køleskab eller et TV ikke lever op til det almindelige krav om normal holdbarhed, som følger af det generelle mangelsbegreb.

Det er salgsgenstandens beskaffenhed på tidspunktet for risikoens overgang (dvs. normalt leveringen, som i forbrugerkøb typisk sker ved overgivelsen til forbrugeren), der er afgørende ved mangelsbedømmelsen. $^{32}$

Forringelser, der skyldes forhold indtruffet efter risikoens overgang, såsom for eksempel forbrugerens uforsvarligt hårdhændede behandling af salgsgenstanden og skader forvoldt af tredjemand, udgør ikke nogen køberetlig mangel.

Forringelser, der skyldes sådanne udefra kommende forhold, og ikke varens iboende egenskaber, er typisk heller ikke omfattet af tillægsforsikringernes dækning af funktionsfejl med videre. Derimod kan de meget vel være omfattet af tillægsforsikringer, der dækker (også) udefra kommende „pludselige og uforudsete hændelser“ eller „hændelige uheld“, 33 jf. nærmere herom under 3.1.3.

Efter køberetlige regler gælder dog ikke undtagelsefrit, at forringelser, der skyldes forhold indtruffet efter risikoens overgang, falder uden for mangelsbegrebet. Der gøres navnlig undtagelse for forringelser, der skyldes, at sælgeren ikke har opfyldt sine forpligtelser efter aftalen. ${ }^{34}$ Forhold, der kan henføres til sælgerens manglende opfyldelse af sine aftalemæssige forpligtelser, udgør således altid en mangel. Beskadiges salgsgenstanden på grund af f. eks. forkert montering, anvendelse, opbevaring eller vedligeholdelse, og kan dette henføres til sælgerens manglende op-

\footnotetext{
${ }^{30}$ Der ses foreløbig bort fra de forskelle der kan gøre sig gældende med hensyn til bevismæssige forhold. Se nærmere herom i teksten nedenfor.

${ }^{31}$ Se nærmere teksten nedenfor om forhold, der kan henføres til sælgerens manglende opfyldelse af aftalemæssige forpligtelser.

${ }^{32}$ Se nærmere herved og til det følgende dansk KBL $\S \S 77 a$, finsk KSL 5.kap. § 15., islandsk FKL $\S 18$, norsk FKPL $\S 18$ og svensk KKPL $\S 20$.

${ }^{33}$ Se fx bilag 2.1, bilag 2.5, bilag 2.7, bilag 2.14 og bilag 2.15.

${ }^{34}$ Jf. dansk KBL $\S \S 77$ a, stk. 2, finsk KSL 5. kap. § 15, stk. 3, islandsk FKL 18, stk. 3, norsk FKPL § 18, stk. 3, og svensk KKPL § 20, stk. 3.
} 
fyldelse af f.eks. forpligtelsen til at give fornødne oplysninger om montering, anvendelse, opbevaring og vedligeholdelse, foreligger der således også en køberetlig mangel, selv om beskadigelsen er sket efter risikoens overgang. På tilsvarende måde kan det i sig selv udgøre en mangel, hvis sælgeren under afhjælpning af en køberetlig mangel, påfører salgsgenstanden en skade.

Det følger af det anførte, at det ved afgørelsen af, om en reklamation angående mangler er berettiget, er afgørende, om en kvalitetsafvigelse, der viser sig nogen tid efter købet, og som alt andet lige udgør en mangel, også var til stede på tidspunktet for risikoens overgang, dvs. normalt da salgsgenstanden blev overgivet til køberen. Var kvalitetsafvigelsen til stede på dette tidspunkt, foreligger der en mangel, og sælgeren hæfter herfor, også selv om kvalitetsafvigelsen først har vist sig på det senere tidspunkt. Skyldes kvalitetsafvigelsen derimod forhold indtruffet efter tidspunktet for risikoens overgang, foreligger der normalt ikke en mangel, idet salgsgenstanden i så fald opfyldte kvalitetskravene på det relevante tidspunkt. Sådanne efterfølgende forhold kan tænkes at være køberens uhensigtsmæssige behandling af genstanden, tredjemands forhold eller en naturbegivenhed.

I overensstemmelse med almindelige principper om bevisbyrdefordeling var det før implementeringen af forbrugerkøbsdirektivet (1999/44/EF) som udgangspunkt forbrugeren, det gik ud over, hvis der er relevant faktuel tvivl om, hvorvidt der foreligger en kvalitetsafvigelse, eller hvorvidt denne var (latent) til stede også på tidspunktet for risikoens overgang, dvs. normalt overgivelsen af salgsgenstanden til forbrugeren.

Dette er i sidstnævnte henseende fraveget efter gennemførelsen af direktivet, idet en påvist manglende overensstemmelse med de kvalitetskrav, der følger af aftalen, i en periode på seks måneder efter leveringen, formodes at have været tilstede også på det nævnte tidspunkt, medmindre denne formodning er uforenelig med salgsgenstandens eller den manglende overensstemmelses art. ${ }^{35}$ For at afkræfte formodningen må sælgeren kunne pege på forhold, som kan afsvække formodningen, for eksempel påvise, at en beskadigelse er indtruffet efter risikoens overgang.

Gennemførelsen af direktivets formodningsregel i de nordiske landes forbrugerkøbslovgivning er, retligt set, alene udtryk for en overvejende teknisk tilpasning, der ikke kan antages at have medført nogen væsentlig ændring af bevisbyrden i de første seks måneder, ${ }^{36}$ og har ikke ændret den hidtidige retstilstand i perioden derefter, hvor bevisbyrden vedrørende mangelspørgsmålet både formelt og reelt er uændret. Også under den hidtidige retstilstand (hvor der ikke gjaldt nogen særlig bevisregel) var kravene til forbrugerens bevisførelse forholdsvis beskedne, når en defekt

\footnotetext{
${ }^{35}$ Jf. direktiv 99/44/EF art. 5, stk. 3, der er gennemført ved dansk KBL $\S § 7$ a, stk. 2, finsk KSL 5.kap. § 15, stk. 2, islandsk FKL § 18, stk. 2, norsk FKPL § 18, stk. 2, og svensk KKPL § 20 a.

${ }^{36}$ Jf. Viggo Hagstrøm: Kjøpsrett (2005) s. 89, samt den danske betænkning 1403/2001 om gennemførelse af forbrugerkøbsdirektivet s. 89 ff. og s. $189 \mathrm{f}$.
} 
ved nye genstande med en vis forventet længere levetid viser sig efter kort tid.

Uden for formodningsreglens anvendelsesområde (dvs. i de nævnte undtagelsestilfælde og efter 6 måneder regnet fra levering) anvendes almindelige bevisprincipper, hvorefter bevisbyrden normalt påhviler køberen, men således at de nærmere krav, der stilles til beviset for, at der foreligger en køberetlig mangel, beror på de konkrete forhold, ligesom det var tilfældet før direktivets implementering. Der er intet grundlag for at tillægge indførelsen af den direktivdikterede seks måneders regel den virkning, at der efter seks måneders perioden er sket en forringelse af forbrugerens retsstilling gennem en skærpelse af de bevismæssige krav for, at der kan statueres en mangel.

Selv om det således ikke ville være berettiget at slutte modsætningsvis fra seks måneders formodningsreglen med den følge, at mangelsindsigelser, der fremsættes efter udløbet af fristen for formodningsreglen, afvises alene under henvisning til, at der er forløbet mere end seks måneder, og at forbrugeren ikke har godtgjort, at kvalitetsafvigelsen også var til stede på leveringstidspunktet, synes der ikke desto mindre i virksomhedernes praksis, i hvert fald i den første tid efter indførelsen af de nye regler, i det praktiske $\operatorname{liv}^{37}$ at have været en tendens til at skærpe de bevismæssige krav til forbrugerkøbere, som reklamerer over mangler, der først har vist sig mere end seks måneder efter leveringen. Hvorvidt dette skyldes en misforståelse af lovændringens betydning for retsstillingen, eller en opgivelse af tidligere tiders mere imødekommende holdning („kulance“), unddrager sig udredernes erkendelse.

I relation til tillægsforsikringernes dækning af funktionsfejl indebærer bevisfordelingen i overensstemmelse med almindelige forsikringsretlige principper, at det påhviler den sikrede, dvs. forbrugeren, at sandsynliggøre, at der er indtruffet en forsikringsbegivenhed, dvs. in casu „funktionsfejl“. Jf. for eksempel det danske Forsikringsankencevnets sag 62.956 og sag 59.348, hvor det ikke var godtgjort, at der forelå en fejl ved bærbar pc. ${ }^{38}$

Dersom det kan lægges til grund, at forsikringsbegivenheden er indtrådt, må selskabet, for at undgå dækning, kunne dokumentere, at der foreligger særlige forhold, som i henhold til forsikringsvilkårene og forsikringslovgivningen kan begrunde, at selskabet alligevel kan undgå ansvar.

Jf. for eksempel det danske Forsikringsankencevnets sag 47.370, hvor reparation af en vaskemaskine ca. 4 år efter købet var dækningsberettiget, idet selskabet ikke havde godtgjort, at skaden på klagerens vaskemaskine skyldtes „slitage“, hvorfor det ikke var godtgjort, at forsikringsvilkårenes dækningsundtagelse herom fandt anvendelse. Derimod blev det i Forsik-

\footnotetext{
${ }^{37}$ Jf. for Danmarks vedkommende oplysningerne i Bo Kristensen m. fl.: Nye regler om forbrugerkøb - en empirisk undersøgelse (2005) s. 15 ff.

${ }^{38}$ Se også under 3.1 .3 om de modsvarende bevisspørgsmål i relation til "pludselig og uforudset skade" mv.
} 
ringsankencevnets sag 47.257 på grundlag af oplysningerne fra en reparatør, der havde undersøgt en ca. 21/2 år gammel videomaskine, lagt til grund, at funktionssvigtet skyldtes normalt slid og manglende vedligeholdelse omfattet af tillægsforsikringens dækningsundtagelser.

Ved „varige“ forbrugsgoder af den art, som der typisk tegnes tillægsforsikring for, synes de bevismæssige forhold angående mangelsbedømmelsen i det praktiske liv ikke hyppigt at give anledning til relevant faktuel tvivl for den, der har teknisk indsigt. En teknisk undersøgelse kan således ofte eliminere faktuel tvivl med hensyn til, om et apparats manglende funktion skyldes apparatets iboende egenskaber (konstruktions-, materiale- eller fabrikationsfejl), dvs. en køberetlig mangel, eller udefra kommende forhold indtruffet efter leveringen (såsom forbrugerens eller tredjemands uforsvarligt, hårdhændede behandling, et uheld, eller mangelfuld vedligeholdelse, trods forsvarlig instruktion herom).

Det siger sig selv, at den praktiske betydning af de bevismæssige forhold, alt andet lige, afhænger af tidsfaktoren. Ved „varige“ forbrugsgoder af den art, som der typisk tegnes tillægsforsikring for, er der normalt næppe væsentlig forskel på forbrugerens retsstilling i bevismæssig henseende for eksempel 5 og 9 måneder efter købet, dvs. henholdsvis en måned før og 3 måneder efter udløbet af den seks måneders formodningsregel angående køberetlige mangler. Det er dog klart, at de bevismæssige muligheder, alt andet lige, forringes i takt med, at tiden går, og at det, når et eller andet tidspunkt passeres, før eller siden må siges, at det kan være en væsentlig forbedring for køberen, at denne blot skal påvise, at der foreligger et funktionssvigt, hvorefter det bliver forsikringsselskabets opgave at dokumentere, at apparatets manglende funktion beror på andre forhold end dets iboende egenskaber.

Ved langvarige tillægsforsikringer for funktionsfejl medfører de bevismæssige lettelser for forbrugeren således, alt andet lige, at forbrugeren formentlig indtager en bedre bevismæssig position end den, der følger af køberetlige regler om mangler.

\subsubsection{Tillæegsforsikringsbegivenheden ctr. garantidæekning}

Af samme grunde, som betinger, at interessen under 3.1.1 samlede sig om de såkaldte generelle mangler, samler interessen for garantiernes vedkommende i den foreliggende sammenhæng sig om de kvalitetskrav, forbrugeren kan støtte på standardiserede garantitilsagn, hvorimod individuelt, særligt aftalte garantitilsagn på samme måde som det individuelle mangelsbegreb kan lades ude af betragtning i den her behandlede sammenhæng.

De kvalitetskrav, der kan stilles i henhold til standardiserede garantitilsagn angående forbrugsgoder af den art, der tiltrækker sig opmærksomhed ved tegning af tillægsforsikringer, angår typisk varens funktionsdygtighed, herunder dens holdbarhed, i en nærmere angivet periode. I mangel 
af holdepunkt for andet fortolkes de kvalitetskrav, der følger sådanne standardiserede garantier i overensstemmelse med det køberetlige mangelsbegreb (med den forskel der følger af det nedenfor anførte om de bevismæssige forhold). ${ }^{39}$

Det er salgsgenstandens beskaffenhed på tidspunktet for risikoens overgang (dvs. normalt leveringen, som i praksis typisk sker ved varens fysiske overgivelse til forbrugeren), der er afgørende ved mangelsbedømmelsen. ${ }^{40}$ Som udgangspunkt gælder det samme ved fortolkningen af garantitilsagn, idet særligt bemærkes, at garantitilsagn, der angår „varige“ forbrugsgoder og indeholder en tidsangivelse normalt fortolkes som en garanti for, at varen ved normal anvendelse kan fungere hele garantiperioden. $^{41}$

Forringelser, der skyldes forhold indtruffet efter risikoens overgang, såsom for eksempel forbrugerens uforsvarligt hårdhændede behandling og skader forvoldt af tredjemand, kan i mangel af holdepunkt for andet ikke begrunde garantikrav.

Ligesom der i relation til spørgsmålet om køberetlige mangler gælder en direktivdikteret formodningsregel i de første seks måneder, er der også ved garantitilsagn af den art, der har interesse i den foreliggende sammenhæng, en formodning for, at en påvist kvalitetsafvigelse udgør garantisvigt. Med hensyn til garantisvigt er formodningen imidlertid ikke begrænset til de første seks måneder, men gælder i hele garantiperioden. ${ }^{42}$

Som allerede nævnt (under 3.1.1) afhænger den praktiske betydning af de bevismæssige forhold i høj grad af tidsfaktoren. I og med, at den bevismæssige formodning af garantitilsagn gælder i hele garantitiden, giver en tillægsforsikring, alt andet lige, ikke forbrugeren nogen relevant bevismæssig fordel, som rækker ud over den, der følger af garantitilsagnet.

\subsubsection{Tillægsforsikringsbegivenheden ctr. indboforsikringsdcekning ${ }^{43}$}

Langt de fleste husstande i de nordiske lande synes at være omfattet af en indboforsikring (svensk: hemförsäkring). ${ }^{44}$

\footnotetext{
${ }^{39}$ Se nærmere Børge Dahl og Peter Møgelvang-Hansen: Garantier - forbrugerbeskyttelse og forbrugerproblemer i de nordiske lande (1985) s. $52 \mathrm{ff}$.

${ }^{40}$ Se nærmere herved og til det følgende dansk KBL $\S \S 77 a$, finsk KSL 5.kap., § 15, islandsk FKL § 18, norsk FKPL § 18 og svensk KKPL § 20.

${ }^{41}$ Se nærmere Børge Dahl og Peter Møgelvang-Hansen: Garantier - forbrugerbeskyttelse og forbrugerproblemer i de nordiske lande (1985) s. 55 og s. 58 ff. om forskellen på egenskabs/Alménog funktionsgarantier. Se herom også Viggo Hagstrøm: Kjøpsrett (2005) s. 200 f.

42 Jf. finsk KSL 5. kap. § 15 og svensk KKPL § 21. I de øvrige nordiske lande er reglen ikke lovfæstet, men fast antaget i teori og praksis. Jf. Børge Dahl og Peter Møgelvang-Hansen: Garantier forbrugerbeskyttelse og forbrugerproblemer i de nordiske lande (1985) s. 55 ff og Viggo Hagstrøm: Kjøpsrett (2005) s. 200.

${ }^{43}$ Indboforsikringer og tillægsforsikringer er reguleret af forsikringsaftalelovgivningens forbrugerbeskyttende regler. De respektive landes FAL var oprindelig stort set identiske, idet de var et resultat af et tværnordisk samarbejde i begyndelsen af 1900-tallet. I nyere tid er der gennemført moderniseringer af loven i Sverige, Norge og Finland. De grundlæggende principper er dog fortsat i al væsentlighed identiske. For Danmarks vedkommende findes reglerne i lovbekendtgørelse 726/1986 med senere ændringer; Finland: Lag 543/1994, Island: lov 30/2004; Norge: Lov 1989-0616-69 med senere ændringer; Sverige: Lag 2005:104.
} 
En indboforsikring tegnes normalt ikke som en selvstændig forsikring, men indgår ofte som en del af en kombineret forsikring, for eksempel en familieforsikring, husstandsforsikring el. lign. Udtrykket „indboforsikring“ er derfor i det følgende anvendt også om familieforsikringer og eventuelle andre forsikringer, der kombinerer en indboforsikring med andre forsikringsprodukter.

Indboforsikringer dækker i almindelighed ting, der befinder sig i eller ved forsikringstagerens helårsbolig. De ting, der omfattes af forsikringen, er først og fremmest indbogenstande eller „privat indbo“, som er det udtryk, der typisk anvendes i forsikringsvilkårene. Privat indbo er ting, der naturligt forekommer $\mathrm{i}$ et almindeligt, privat hjem. I praksis fortolkes begrebet temmelig vidt. ${ }^{45}$

Indboforsikringers typiske dækningsområde er skader, der skyldes række nærmere angivne pludselige udefra kommende begivenheder. Kerneområdet er brand- og vandskader, (visse former for) tyveri, og hærværk.

En almindelig indboforsikring dækker således typisk situationer, hvor indbo og private ejendele beskadiges eller bortkommer som følge af udefra kommende påvirkninger såsom brand, lynnedslag, eksplosion, (visse former for) tyveri, hærværk, vandskade samt stormskade.

I det omfang tillægsforsikringerne alene dækker „funktionsfejl“ , ${ }^{46}$ overlapper de således ikke den typiske indboforsikring. ${ }^{47}$

Mange tillægsforsikringer omfatter imidlertid (også) „pludselige og uforudsete udefra kommende hændelser ${ }^{\text {“48 }}$ og/eller visse former for (indbruds)tyveri, ${ }^{49}$ og overlapper derved i større eller mindre omfang dækningen ifølge den typiske indboforsikring.

Tillægsforsikringer, der dækker „pludselige og uforudsete udefra kommende hændelser“" adskiller sig dog fra de fleste indboforsikringer derved, at de typisk også omfatter andre uheld end sådanne, der er udslag af nærmere opregnede, specificerede risici, såsom brand- vand- og hærværksskade med videre, der kendetegner de fleste indboforsikringer.

Tillægsforsikringerne omfatter således, alt andet lige, også skader, der er forvoldt ved bl.a. forbrugerens egen adfærd.

Jf. således for eksempel det norske Forsikringsskadenemndas sag 4619, hvor forbrugeren under græsslåning tabte sin mobiltelefon ud af lommen og derefter kørte den over med plæneklipperen, samt det svenske Allmänna Reklamationsnämndens sag 2004-6793, hvor forbrugeren un-

\footnotetext{
${ }^{44}$ Efter det for udrederne oplyste drejer det sig for Danmark, Norge og Sveriges vedkommende om mindst $90 \%$. I Finland mindst $75 \%$. Der foreligger ikke oplysninger vedrørende Island.

${ }^{45}$ Henning Jønsson \& Lisbeth Kjærgaard: Dansk Forsikringsret (2003), s. 644, med beskrivelse af praksis efter dansk ret.

${ }^{46}$ Se nærmere herom under 3.1.1 og fx bilag 2.2 og bilag 2.4.

${ }^{47}$ Men derimod i et vist omfang køberetlige regler om mangler og eventuelle garantitilsagn, se nærmere herom under 3.1.1 og 3.1.2.

${ }^{48}$ Se generelt ovenfor i afsnit 2.5.2 og fx bilag 2.5 og bilag 2.6. Se også bilag 2.13, bilag 2.14 og bilag 2.15, der alle anvender termen "hændelige uheld”, der som nærmere omtalt i teksten nedenfor er egnet til at vildlede med hensyn til dækningsomfanget.

${ }^{49}$ Se fx bilag 2.3 (delvis), bilag 2.6 (indbrudstyveri), bilag 2.15 (indbrudstyveri).
} 
der en cykeltur havde tabt sit videokamera på en grusvej. Også i det svenske Allmänna Reklamationsnämndens sag 2005-1897 forelå der en pludselig og uforudset hændelse; et TV blev brandskadet af en kobberlysestage, der var anbragt oven på apparatet og fik dets overflade til at smelte.

I det danske Forsikringsankencevnets sag 62.741 måtte det tilskrives ovnens konstruktion, at der løb vand ud, og at emaljen skallede af. Nævnet fandt derfor ikke, at der forelå en udefra kommende eller pludselig eller uforudset hændelse, som kunne begrunde dækning i henhold til tillægsforsikringen.

I overensstemmelse med almindelige forsikringsretlige bevisprincipper går det ud over den sikrede, dvs. forbrugeren, hvis det ikke sandsynliggøres, at der er indtruffet en forsikringsbegivenhed, dvs. in casu at der er er indtruffet en udefra kommende, pludselig og uforudset skade, jf for eksempel det svenske Allmänna Reklamationsnämndens sag 2004-8426, hvor det, bl.a. på grund af forbrugerens forskellige forklaringer ikke var sandsynliggjort, at en computers manglende funktion på grund af en fugtskade var omfattet af forsikringen. Til yderligere illustration kan nævnes det norske Forsikringsskadenemndas sag 5657, hvor nævnets flertal nåede til det modsatte resultat i et tilfælde, hvor der spørgsmål om, hvorvidt en fugtskade ved en mobiltelefon skyldtes et uheld under en kanotur.

Som nævnt ovenfor omfatter tillægsforsikringsdækning af udefra kommende pludselige og uforudsete skader, alt andet lige, også skader, der er forvoldt af forbrugeren selv. I disse tilfælde følger det af forsikringsaftalelovgivningens almindelige regler om sikredes fremkaldelse af forsikringsbegivenheden, ${ }^{50}$ at selskabet alt andet lige hæfter uden begrænsninger, hvis skaden er forvoldt, uden at forbrugeren har handlet uagtsomt, eller hvis der kun er handlet simpelt uagtsomt, dvs. at selskabets hæftelse kun kan bortfalde eller begrænses, dersom forbrugeren har handlet forsætligt eller groft uagtsomt. ${ }^{51}$

At dømme efter udformningen af vilkårene i visse tillægsforsikringer $^{52}$ og klagenævnspraksis ${ }^{53}$ synes kendskabet til eller forståelsen af disse regler hos visse af aktørerne på markedet undertiden at være temmelig beskeden. I overensstemmelse med almindelige forsikringsretlige bevisprincipper går det ud over selskabet, hvis der er relevant faktuel

${ }^{50}$ Se dansk FAL $\S 18$ og 20, finsk FAL § 30, islandsk FAL § 27, norsk FAL § 13-9 og svensk FAL kap. 4, § 5 .

${ }^{51}$ Jf. til illustration det norske Forsikringsklagenemndas tidligere kort omtalte sag 4619 om forbrugerens tab og efterfølgende overkørsel af mobiltelefon under græsslåning. Nævnet udtalte bl.a., at et krav i forsikringsvilkårene om, at den pludselige og uforudsete ydre begivenhed ikke måtte være fremkaldt af sikrede selv, udgjorde en såkaldt "skjult handlingsklausul”, som ikke kunne stille selskabet bedre end forsikringsaftalelovgivningens regler om sikredes fremkaldelse af forsikringsbegivenheden (eller reglerne om sikkerhedsforskrifter, jf. herom i teksten nedenfor).

${ }^{52}$ Se fx bilag 2.13, bilag 2.14 og bilag 2.15, der alle definerer forsikringsbegivenheden som "hændelige uheld”, men som altså efter det anførte også omfatter forbrugerens simpelt uagtsomme handlinger; derimod er det i og for sig i overensstemmelse med reglerne om sikredes fremkaldelse af forsikringsbegivenheden, når fx bilag 2.13 og 2.15 gør undtagelse for grov uagtsomhed og forsæt.

${ }^{53}$ Se klagenævnssager omtalt i teksten straks i det følgende. 
tvivl med hensyn til, om forbrugeren har handlet groft uagtsomt eller forsætligt, eller forholdet i øvrigt er omfattet af en dækningsundtagelse.

Jf. til illustration for eksempel det norske Forsikringsklagenemndas sag 4386, hvor flertallet fandt, at der forelå en skade dækket af tillægsforsikringen i et tilfælde, hvor forbrugeren tabte sin mobiltelefon i vandet, da han under udskiftning af vinduer på en båd snublede over en genstand. Lignende afgørelser i Forsikringsnemndas sager 4385, 3810 og det danske Forsikringsankencevnets sag 59.401.

I det danske Forsikringsankencevnets sag 61.109 havde forbrugeren ikke tømt sine lommer, inden han lagde tøjet i vaskemaskine og derefter tørretumbler. Selskabet skulle dække skaden som „hændeligt uheld“, idet forbrugeren ikke fandtes at have fremkaldt forsikringsbegivenheden ved grov uagtsomhed. Samme problemstilling og resultat i Forsikringsankencevnets sag 66.125, hvor forbrugeren havde tabt sin mobiltelefon ud af lommen, da han steg ind i sin bil, hvorefter han kørte over den, da han bakkede ud fra parkeringsbåsen; skaden skulle dækkes som „hændeligt uheld“, idet der højst var udvist simpel uagtsomhed.

I det danske Forsikringsankencevnets sag 62.950 havde en forbruger tegnet en tillægsforsikring (konkret benævnt „tryghedsforsikring“) i forbindelse med køb af en bærbar pc. Forbrugeren tabte senere pc'en på gulvet, idet lynlåsen i den taske pc'en lå i, ikke var låst. Forsikringsselskabet afviste imidlertid at dække skaden under henvisning til, at der ikke var tale om et hændeligt uheld, men om uagtsomhed fra forbrugerens side, hvilket forsikringen ikke dækkede. Nævnet fastslog, at vilkåret om, at kun hændelige uheld dækkes, var i strid med FAL § 20, og at forbrugeren derfor havde krav på dækning, hvad enten skaden var et resultat af et hændeligt uheld eller en uagtsom handling. ${ }^{54}$

I det svenske Allmänna Reklamationsnämndens sag 2005-3817 blev det anset for groft uagtsomt at efterlade taske med computer i 10 minutter på parkbænk under biblioteksbesøg, hvorfor tillægsforsikringsdækningen blev nedsat med 50 \%. Jf. herved det danske Forsikringsankenæevnets sag 59.369, hvor taske med pc under togrejse blev stjålet fra bagagenet lige over forbrugerens passagersæde; ikke grov uagtsomhed.

I det svenske Allmänna Reklamationsnämndens sager 2004-5811 og 2004-5819 udtalte nævnet, at det forhold, at forbrugeren var meget beruset, da han blev frastjålet vidoekamera og ur, ikke i sig selv udgjorde en sådan uagtsomhed, som kunne begrunde nedsættelse af forsikringsdækningen.

Har forbrugeren handlet uagtsomt, men er uagtsomheden alene simpel, kan forholdet alene begrunde manglende dækning eller reduktion af forsikringsdækningen, hvis der er tale om tilsidesættelse af en sikkerheds-

\footnotetext{
${ }^{54}$ Jf. ligeledes kendelse i Forsikringsankencevnets sag nr. 62.570, der vedrørte samme tillægsforsikring fra samme forsikringsselskab. Se tillige sag $n r .59 .346$.
} 
forskrift, som har præciseret bestemte forholdsregler, som forbrugeren skal iagttage for at undgå skade. ${ }^{55}$

Jf. det svenske Allmänna Reklamationsnämndens sag 2005-3037, hvor det fremgik af tillægsforsikringens vilkår, at mobiltelefoner ikke måtte efterlades uden tilsyn på offentlige steder, og at forsikringsdækningen i givet fald kunne reduceres med 50 \%. Forsikringsselskabet påberåbte sig i første række, at skaden ikke var dækningsberettiget, idet den var fremkaldt ved grov uagtsomhed, men fik ikke medhold i, at der forelå grov uagtsomhed. Derimod fandt nævnet, at sikkerhedsforskriften var tilsidesat, og at dækningen derfor skulle nedsættes med $50 \%$.

Visse af de dækningsundtagelser, der hyppigt findes i tillægsforsikringer, lever ikke op til de krav, der efter forsikringslovgivningen må stilles, for at vilkårene kan tillægges virkning som sikkerhedsforskrifter, jf. i denne retning formentlig det danske Forsikringsankencevnets sag 47.574 om tab af en mobiltelefon fra brystlomme:

\footnotetext{
„Det er nævnets opfattelse, at skaden på mobiltelefonen hverken er en følge af 'uforsvarlig anvendelse og betjening af apparatet' eller af 'dårlig pleje eller manglende vedligeholdelse'. Nævnet finder derfor, at selskabet skal yde klageren forsikringsdækning.

Nævnet bemærker herved, at brug af undtagelsesbestemmelsen om uforsvarlig anvendelse og betjening af apparatet må forudsætte, at den sikrede har fremkaldt forsikringsbegivenheden ved en uagtsomhed, der kan tilregnes ham som (mindst) groft uagtsom, jf. forsikringsaftalelovens § 20.“
}

I det norske Forsikringsklagenemndas sag 3341 var der ikke givet forbrugeren tilstrækkelig information om en sikkerhedsforskrift, hvorefter mobiltelefoner efterladt i biler skulle opbevares i lukket handskerum eller låst bagagerum.

Det skitserede billede af forskellen på dækningsområdet for henholdsvis tillægsforsikringer, der omfatter pludselige og uforudsete udefra kommende hændelser, og for de almindelige indboforsikringer er dog ikke skarpt, idet det i praksis ofte ser anderledes ud på grund af de mange tilvalgsmuligheder, som såvel indbo- som tillægsforsikringerne rummer.

De fleste almindelige indboforsikringer kan således, mod betaling af en højere forsikringspræmie, udvides til at dække også for eksempel elskader (skader udløst af kortslutning af elektriske apparater) og/eller med en glas- og kummeskader.

Mange indboforsikringer giver endvidere mulighed for, ved betaling af en forhøjet præmie, at udvide dækningen til også at gælde andre pludselige skader end dem, der er udslag af de specifikt opregnede risici (brand-, vand, hærværk etc.), med den virkning, at indboforsikringen kommer til at omfatte også skader på ting forvoldt ved for eksempel husstandens egen adfærd (i hvilket tilfælde forsikringen ofte betegnes en „all

\footnotetext{
${ }^{55}$ Se nærmere dansk FAL § 51, finsk FAL § 31, islandsk FAL § 26, norsk FAL § 4-8, jf. § 1-2, litra e, samt svensk FAL 4 kap. $\S 6$.
} 
risk“-forsikring). I så fald er dækningsområdet for de „opgraderede“ indboforsikringer meget lig dækningsområdet for tillægsforsikringer. ${ }^{56}$

Endvidere dækker mange (udvidede) tillægsforsikringer også visse former for tyveri. Her er der ligeledes tale om overlapning med dækningen i henhold til de fleste almindelige indboforsikringer. Graden af overlapning i så henseende og overlapningens praktiske betydning for forbrugeren afhænger dog i høj grad af de konkrete forhold.

Er der tale let transportable genstande såsom mobiltelefoner, digitale kameraer, musikafspillere, bærbare computere kan det have temmelig stor betydning for forbrugerens eventuelle fordele ved at tegne tillægsforsikring, om denne dækker enhver form for tyveri, eller om dækningen er begrænset til for eksempel indbrudstyveri. Jf. for eksempel det svenske Allmänna Reklamationsnämndens sag 2004-4922, hvor sidstnævnte var tilfældet, og tillægsforsikringen derfor ikke skulle dække tyveri af en computer, der blev stjålet under forbrugerens flytning. Tilsvarende eksempel findes i Allmänna Reklamationsnämndens sag 2005-2483, hvor en tillægsforsikring, der begrænsede tyveridækningen til indbrudstyveri ikke skulle dække et digitalkamera, der var stjålet fra forbrugeren under en håndboldkamp.

En særlig situation, som understreger det ovenfor anførte synspunkt, forelå i det danske Forsikringsankencevnets sag 62.786. Nævnet udtalte bl.a.:

„....må efter de foreliggende oplysninger lægge til grund, at den bærbare pc ikke er stjålet ved et indbrudstyveri, jf. forsikringsbetingelsernes punkt 2. I brochurematerialet har selskabet efter nævnets opfattelse ikke begrænset dækningen til kun at gælde ved indbrudstyveri. Heroverfor er der i forsikringsbetingelserne gjort så væsentlige indskrænkninger i dækningen, at selskabet - også henset til at netop dækningen for andre former for tyveri end indbrudstyveri er et vilkår, der må antages at være af central betydning for forbrugernes valg af tryghedsforsikringen i brochuren burde have gjort særligt opmærksom på, at forsikringen kun ville yde dækning ved tyveri, hvis dette kunne karakteriseres som indbrudstyveri.

På den således anførte baggrund finder nævnet, at selskabet - med tillæg af renter efterforsikringsaftalelovens § 24 - skal yde klageren forsikringsdækning for tyveriet af den bærbare pc. “

Modsat har en tillægsforsikrings tyveridækning typisk næppe nogen stor praktisk betydning for den forbruger, der køber en dybfryser eller en vaskemaskine. Drejer det sig om stationært udstyr, såsom computerudstyr og tv-udstyr, fladskærme med videre kan indbrudstyveridækning have stor betydning (men vil som regel følge af indboforsikringen), mens spørgsmålet om dækning af simpelt tyveri i disse tilfælde vel ofte spiller en mindre rolle i det praktiske liv.

Der vil således ofte være en større eller mindre grad af sammenfald i dækningsområdet for indbo- og tillægsforsikringer. Idet de fleste husstande som nævnt har tegnet en eller anden form for indboforsikring, kan

\footnotetext{
56 Jf. om udvidede tillægsforsikringer afsnit 2.5.2 ovenfor.
} 
fordelene ved en tillægsforsikring undertiden være temmelig beskedne sammenlignet med den dækning, der er forbundet med indboforsikringen.

Den mest iøjnefaldende forbedring, der kan gøre sig gældende, er formentlig oftest, at en tillægsforsikring i et eller andet omfang omfatter også risikoen for anden pludselig og uforudset hændelse (end brand, vand, hærværk med videre), som ikke i almindelighed dækkes af indboforsikringen, men ofte kræver særligt tilvalg (og forhøjet præmie). Betydningen af denne typiske forbedring må i antages i vidt omfang at afhænge af varens art og forbrugerens og husstandens nærmere forhold (børn, husdyr etc.)

\subsection{Dækningsperioden}

\subsubsection{Tillcegsforsikringstiden ctr. køberetlige regler om reklamation.}

Når det drejer sig om længden af den absolutte reklamationsfrist, hvis oversiddelse som udgangspunkt ${ }^{57}$ afskærer forbruger fra at påberåbe sig mangelsbeføjelser, gælder vidt forskellige regler i de nordiske lande.

Mens Danmark i overenstemmelse med minimumskravet i forbrugerkøbsdirektivets art. 5, stk. 1, har fastsat en almindelig absolut reklamationsfrist på to år, regnet fra salgsgenstandens overgivelse, ${ }^{58}$ gælder der ingen særlig absolut reklamationsfrist i finsk ret (der alene regulerer forholdet efter de almindelige regler om forældelse af fordringer). I Island og Norge er den absolutte reklamationsfrist „to år etter at forbrukeren overtok tingen. Dersom tingen eller deler av den ved vanlig bruk er ment å vare vesentlig lengre, er fristen for å reklamere fem år““ ${ }^{59}$ I Sverige er den absolutte reklamationsret 3 år. ${ }^{60}$

I det omfang en tillægsforsikring dækker funktionsfejl i en periode, der er længere end den absolutte reklamationsfrist, indebærer den en klar forbedring, idet købelovgivningens regler udtrykkeligt fastslår, at risikoen for funktionsfejl med videre efter fristens udløb i mangel af længerevarende garanti er forbrugerens.

I praksis tegnes tillægsforsikringer oftest for en periode på 3 eller 5 år (regnet fra købsdatoen); forsikringsperioden for mobiltelefoner synes dog normalt ikke at overstige 2 år. ${ }^{61}$

Tillægsforsikringstidens længde udgør således ikke i sig selv ${ }^{62}$ en forbedring af forbrugerkøberens retsstilling, når den sammenholdes med,

\footnotetext{
${ }^{57}$ Fristen gælder ikke, hvis sælgeren har givet længerevarende garanti eller handlet i strid med almindelig hæderlighed mv.

${ }^{58}$ Jf. dansk KBL § 83, sammenholdt med § 54, stk. 2, som udvider fristen til 5 år ved køb af byggematerialer.

${ }^{59}$ Jf. islandsk FKL $\S 27$, stk. 2, og norsk FKPL § 27, stk. 2, og se nærmere om bestemmelsen Viggo Hagstrøm: Kjøpsrett (2005) s. 187 ff.

${ }^{60}$ Jf. svensk KKPL $\S 23$, stk. 3.

${ }^{61}$ Se fx bilag 2.3 og 2.5 .
} 
hvad der gælder efter finsk, islandsk, norsk og efter omstændighederne svensk ret, idet sådanne funktionsfejl, som er omfattet af tillægsforsikringerne, normalt vil udgøre en køberetlig mangel, hvis de, trods normal anvendelse af genstanden, indtræder inden for 3-5 år.

Jf. herved for eksempel det norske Forbrukertvistutvalgets sag 2004.176 om en Siemens vaskemaskine, der var købt i november 1998, og som i september 2003 standsede midt en vask, fordi afbryderknappen ikke længere virkede. Da dette ikke skyldtes normal slitage, forkert anvendelse eller udefra kommende omstændigheder, som køberen bar risikoen for, var køberen efter norsk FKPL berettiget til vederlagsfri afhjælpning. ${ }^{63}$

Ved en sammenligning med dansk rets absolutte reklamationsfrist på to år er tillægsforsikringstider på 3-5 år angående funktionsfejl derimod i sig selv en fordel for forbrugeren sammenlignet med beskyttelsen efter dansk KBL.

Det er på denne baggrund forståeligt, at visse tillægsforsikringer indeholder bestemmelser om, at de først træder i kraft efter udløbet af den absolutte reklamationsfrist. Herved undgås dobbeltdækning, som bl.a. kunne resultere i, at køberen i praksis risikerede at skulle betale selvrisiko for afhjælpning af køberetlige mangler. ${ }^{64}$ I det omfang tillægsforsikringen ud over funktionsfejl med videre omfatter for eksempel tyveri er det imidlertid klart, at køberen risikerer skuffelse, hvis den udskudte ikrafttræden også gælder den „udvidede“ dækning, og at der er et særligt behov for information om forsikringstidens begyndelse. Se nærmere om denne problemstilling nedenfor i kapitel 4 med omtale af bl.a. det danske Forsikringsankencevnets sager $n r .39 .937$ og 50.739.

Forskellige forhold kan dog begrænse de fordele, der - sammenlignet med købelovgivningen - kan være knyttet til tillægsforsikringstidens længde. Disse forhold synes, ironisk nok, i første række at kunne få praktisk betydning, hvis forbrugeren har været så uheldig at købe et „mandagsprodukt“, dvs. den situation, som vel er i centrum for den, der ønsker at „købe“ ekstra tryghed gennem en tillægsforsikring.

Har forbrugeren været så uheldig at få et mangelfuldt produkt, og sker der omlevering, følger det af køberetlige regler, at forbrugeren ikke er ringere stillet end i tilfælde, hvor den oprindeligt leverede vare var mangelfri. Dette indebærer bl.a., at der fra overgivelsen af den nye vare, be-

\footnotetext{
${ }^{62}$ Om de bevismæssige fordele, der kan være forbundet med en tillægsforsikring henvises til afsnit 3.1, hvor tillige er omtalt den fordel, der kan være forbundet med, at en tillægsforsikring eventuelt også dækker skader forårsaget af sådanne udefra kommende hændelser, som ikke udgør en køberetlig mangel.

${ }^{63}$ Jf. til illustration også det norske Forbrukertvistutvalgets sak 2004.0356, hvor utvalget imødekom en forbrugerkøbers krav om afhjælpning af mangler ved det købte tv i et tilfælde, hvor der var gået ca. 4 år fra købet, og sælgeren havde henvist til, at funktionssvigtet skyldes unormal brug eller mangelfuld vedligeholdelse.

${ }^{64}$ Jf. til illustration også det norske Forbrukertvistutvalgets sak 2004.0356, hvor utvalget imødekom en forbrugerkøbers krav om afhjælpning af mangler ved det købte tv i et tilfælde, hvor der var gået ca. 4 år fra købet, og sælgeren havde henvist til, at funktionssvigtet skyldes unormal brug eller mangelfuld vedligeholdelse.
} 
gynder en ny absolut reklamationsfrist, inden hvilken forbrugeren kan gøre mangelsbeføjelser gældende. Det samme gælder i tilfælde, hvor der ved en mangelsreparation udskiftes væsentlige dele af varen, men i reparationstilfældene gælder den nye frist kun i relation til de udskiftede dele. ${ }^{65}$

Omlevering eller væsentlig reparation i overensstemmelse med køberetlige regler kan således efter omstændighederne indebære, at de køberetlige beføjelser kan gøres gældende i en periode, der er længere end en eventuel tillægsforsikringstid, og at tillægsforsikringen for så vidt bliver overflødig, idet den ikke begrænser forbrugerens risiko i det forventede omfang.

Den beskyttelse, en forbrugerkøber opnår gennem omlevering efter køberetlige regler, indebærer således, at forbrugerens praktiske behov for tillægsforsikringen reduceres. Taget efter ordlyden af de fleste forsikringsvilkår indebærer køberetlig omlevering tilmed, at tillægsforsikringsdækningen ophører, idet dækningen er begrænset til angå en nærmere bestemt angivet salgsgenstand. ${ }^{66}$

Hertil kommer, at mange tillægsforsikringer (tillige) bestemmer, at tillægsforsikringen bortfalder i tilfælde af totalskade (og at forbrugeren i så fald ikke har krav på tilbagebetaling af præmie (såkaldt ristorno)), ${ }^{67}$ dvs. at totalskade i for eksempel år 2 kan udtømme en retsvirkningerne af en 5-årig tillægsforsikring.

I alle de nordiske lande gælder, at forbrugerens ret til at gøre mangelsbeføjelser gældende er betinget af, at reklamation finde sted inden rimelig tid, efter at forbrugeren opdagede manglen ${ }^{68}$ eller burde have opdaget den ${ }^{69}$ (den relative reklamationsfrist). Som foreskrevet i forbrugerkøbsdirektivet art. 5, stk. 2, er det i alle landene bestemt, at reklamation senest to måneder efter, at forbrugeren opdagede manglen, altid er rettidig.

Vilkårene i de undersøgte tillægsforsikringer indeholder temmelig mange variationer på dette punkt. Oftest er i vilkårene angivet, at anmeldelse af skaden skal ske „snarest“ eller „omedelbart“ efter skaden ${ }^{70}$ og undertiden er bestemt, at anmeldelse skal ske senest en vis frist regnet fra enten tidspunktet for forbrugerens kendskab til skaden, eller fra skadetidspunktet. ${ }^{71}$ Afhængig af de nærmere omstændigheder i det enkelte tilfælde kan nogle af disse vilkår indebære, at forbrugeren er undergivet

\footnotetext{
${ }^{65}$ Jf. Johnny Herre (under medverkan av Jan Ramberg): Konsumentköplagen - en kommentar (1999) s. 276 f, Joseph Lookofsky: Køb. Dansk indenlandsk købsret (2. udg. 2002) s. 257 og Viggo Hagstrøm:Kjøpsrett (2005) s. 189.

${ }^{66}$ Se fx bilag 2.2.

${ }^{67}$ Se fx bilag 2.1, bilag 2.13, bilag 2.2, bilag 2.15, bilag 2.6 og bilag 2.10. Se nærmere om tilbagebetalingsspørgsmålet nedenfor i kapitel 4.

${ }^{68}$ Jf. dansk KBL $\S 81$.

${ }^{69}$ Jf. finsk KSL 5.kap. § 16, islandsk FKL § 27, stk. 1, norsk FKPL § 27, stk. 1, og svensk KKPL $\S 23$, stk. 1 .

${ }^{70}$ Se fx bilag 2.2, bilag 2.5 og bilag 2.6 .

${ }^{71}$ Se fx bilag 2.3 (senest 12 måneder efter kendskab), bilag 2.4 (senest 6 måneder fra skadetidspunktet), bilag 2.5 (senest 3 måneder fra kendskab) og bilag 2.6 (senest 12 måneder efter skaden).
} 
en lempeligere eller skrappere reklamationspligt end den, der følger af de køberetlige regler.

\subsubsection{Tillcegsforsikringstid ctr. garantiperiode}

Det er et fastslået princip i nordisk forbrugerbeskyttelseslovgivning, at garantitermen kun må benyttes, hvis forbrugeren i kraft af garantien opnår en væsentlig bedre retsstilling end den, der følger af lovgivningen. I relation til varer af den art, der typisk tegnes tillægsforsikring for, er varens holdbarhed ofte et centralt element. Traditionelt er den forbedring af forbrugerens retsstilling, der er forbundet med garantier for sådanne varer, ofte sket ved give en funktionsgarantier, der i tid går længere end købelovgivningens absolutte reklamationsfrist. I takt med udvidelse af de lovbestemte absolutte reklamationsfrister er denne tendens dog ikke længere så udbredt.

Ikke desto mindre er det klart, at forbrugerens eventuelle fordele ved at tegne en tillægsforsikring også må ses i lyset af en eventuel produktgaranti, som rækker ud over en absolutte reklamationsfrist, ${ }^{72}$ og at tilstedeværelsen af en sådan garanti alt andet lige reducerer de fordele, der kan være forbundet med en tillægsforsikring. ${ }^{73}$

\subsubsection{Tillcegsforsikringstid ctr. indboforsikringstid}

De gængse former for indboforsikringer med videre, som afhængig af forsikringens nærmere dækningsområde i større eller mindre omfang overlapper en tillægsforsikring, ${ }^{74}$ er typisk indgået på det vilkår, at de løber, indtil de opsiges med et vist kortere varsel eller ikke fornyes ved præmiebetaling. En tillægsforsikrings varighed indebærer således ikke i sig selv nogen forbedring af forbrugerens tryghed sammenlignet med den, der er forbundet med indboforsikringen.

\subsection{Dækningens indhold}

\subsubsection{Tillæegsforsikringsydelsen og indboforsikringsydelsen}

Tillægsforsikringsdækningen består normalt $\mathrm{i}$, at selskabet erstatter omkostningerne ved reparation af den skadede genstand, ${ }^{75}$ normalt mod

\footnotetext{
${ }^{72}$ Se også under 3.1.2 om de bevismæssige fordele for forbrugeren ved en garanti.

${ }^{73}$ Sælgerens manglende oplysning til forbrugeren om en garantidækning, som reducerer de fordele, der ellers kan være forbundet med en tillægsforsikring, kan efter omstændighederne føre til, at forbrugeren ikke er bundet af tillægsforsikringsaftalen, se nærmere nedenfor under 4.3.

${ }^{74}$ Se nærmere under 3.1.3.

${ }^{75}$ Se fx bilag 2.1, bilag 2.2, bilag 2.5 og bilag 2.6.
} 
betaling af en vis selvrisiko ${ }^{76}$ og i visse tilfælde således, at forbrugeren selv må afholde visse transportomkostninger. ${ }^{77}$

Overstiger reparationsomkostningerne værdien af et tilsvarende apparat, har selskabet normalt forbeholdt sig retten til at erklære varen for totalskadet og foretage genlevering af en tilsvarende vare eller værdien heraf, eventuelt efter fradrag af selvrisiko og nedskrivning. ${ }^{78}$

Undertiden er det bestemt i vilkårene, at der ikke ydes kontanterstatning. ${ }^{79}$ Et sådant vilkår kan dog ikke udelukke, at forbrugeren efter omstændighederne alligevel har krav på udbetaling af et kontantbeløb. Dette gælder i hvert fald, hvis forsikringen ellers ville være uden reelt indhold, jf. herved det danske Forsikringsankenæevnets sag 59.031, der statuerede, at forbrugeren, trods et sådant vilkår, havde krav på udbetaling af kontanterstatning svarende til det pågældende tv's nedskrevne værdi, dersom et tilsvarende brugt tv ikke kunne leveres til den nedskrevne værdi. Jf. også Forsikringsankenæevnets sag 54.960.

De retlige rammer for tillægsforsikringsydelsen og den forsikringsydelse, forbrugeren har krav på i henhold til indboforsikringen, er de samme.

Vedrørende fastsættelse af erstatning er det den forsikringsretlige hovedregel, at erstatning for en ting fastsættes til det beløb, det vil koste at genanskaffe en tilsvarende ting (genanskaffelsesprisen), med rimeligt fradrag for værdiforringelse, der skyldes alder, brug, nedsat anvendelighed eller andre omstændigheder. ${ }^{80}$ I overensstemmelse hermed, og i lighed med mange tillægsforsikringer, opererer indboforsikringer som regel med løbende afskrivning af værdien af indbogenstande, der skal udskiftes med jævne mellemrum, ligesom indboforsikringer ofte opererer med en selvrisiko. Der er ikke forsikringsretligt noget til hinder for at indsætte vilkår om en selvrisiko, som skal fradrages i erstatningsbeløbet (ud over afskrivningen).

Størrelsen af (eventuel) selvrisiko i indboforsikringer synes jævnligt at udgøre et større beløb end de selvrisikobeløb, der oftest ses i tillægsforsikringer, som således, også i tilfælde af overlappende dækningsområder for indboforsikringen og tillægsforsikringen, på dette punkt kan give forbrugeren en vis økonomisk fordel. ${ }^{81}$

Efter den danske FAL må der for indbogenstandes vedkommende kun ske fradrag for værdiforringelse ved alder og brug, for så vidt genstandens nytteværdi for den sikrede derved er væsentlig nedsat, jf. § 37, stk.

\footnotetext{
${ }^{76}$ Se fx bilag 2.3, bilag 2.5 og bilag 2.6, men ikke fx bilag 2.4 og bilag 2.13 .

${ }^{77}$ Se fx bilag 2.1 og bilag 2.7, der ikke dækker omkostninger ved hjemmebesøg og heller ikke transportomkostninger, medmindre varen skal sendes til et af generalagenten anvist værksted.

${ }^{78}$ Se fx bilag 2.1, bilag 2.2, og bilag 2.5 men ikke bilag 2.3 og bilag 2.6.

${ }^{79}$ Se fx bilag 2.1 og bilag 2.5 .

${ }^{80}$ Jf. den danske FAL $\S 37$, stk. 1, den svenske FAL kap. 6 § 2. Den norske FAL § 6-1, den finske $\S 57$ og den islandske $\S 35$ er formentlig i overensstemmelse hermed.

${ }^{81}$ Dette illustreres klart af bilag 2.3, der "vid stöld.... reducerar hemförsäkringens självrisk” op til 1.000 kr., og som selv opererer med en selvrisiko (ved funktionsfejl) på 195 kr.
} 
2. Er dette ikke tilfældet, sker der ikke fradrag. Bestemmelsen er deklaratorisk. $^{82}$

Reglen i den danske FAL $\S 37$, stk. 2, er præciseret via praksis fra Forsikringsankenævnet. I relation til produkter, der udskiftes med jævne mellemrum - hvorunder falder de typer af forbrugerprodukter, som tillægsforsikringer hovedsagelig knytter sig til, dvs. navnlig elektronikprodukter, hårde hvidevarer med videre - anerkendes i nævnspraksis, at der foretages en vis fast afskrivning i forhold til genanskaffelsesprisen. Afskrivningen opgøres da ofte svarende til forholdet mellem den tid, i hvilken tingen har været brugt ved forsikringsbegivenhedens indtræden, og tingens samlede forventede levetid (hvis altså ikke forsikringsbegivenheden var indtrådt). Har tingen været brugt i 2 år ved forsikringsbegivenheden, og kunne den have været brugt i 10 år, anerkendes en afskrivning på $20 \%$.

Det almindelige forsikringsretlige forbud mod, at skadelidte beriges ved erstatningen (,berigelsesforbuddet“, jf. for dansk rets vedkommende FAL § 39), danner i alle tilfælde overgrænse for erstatningens størrelse. Berigelsesforbuddet indebærer at forsikringstager ikke kan få udbetalt mere i erstatning, end der kræves til skadens dækning. Denne almindelige forsikringsretlige grundsætning gælder også for tillægsforsikringer, hvilket af og til giver anledning til problemer. ${ }^{83}$

Problemerne skyldes, at visse (typisk udvidede) tillægsforsikringer er affattet således, at de kan give forbrugeren anledning til at tro, at der i for eksempel de to første år slet ikke foretages afskrivning i erstatningssummen. Idet FAL § 39 er præceptiv, kan en eventuel uklarhed i forsikringsvilkårene herom imidlertid ikke uden videre fortolkes til fordel for forbrugeren. Problemstillingen behandles uddybende nedenfor i kapitel 4 om fortolkning af tillægsforsikringer.

Udgifter, der er relateret til genanskaffelsen, for eksempel særskilte leveringsomkostninger, kan kræves erstattet som del af genanskaffelsesprisen. Ligeledes kan der fra forfaldstiden ${ }^{84}$ kræves morarenter i overensstemmelse med reglerne herom. ${ }^{85}$ Der er derimod i almindelighed ikke pligt til at dække indirekte tab (for eksempel afsavnstabet ved at skulle undvære en pc indtil genanskaffelsen eller erstatningens udbetaling). ${ }^{86}$

\footnotetext{
${ }^{82}$ Idet der dog efter det danske Forsikringsankenævnets praksis gælder strenge krav til en aftale, der tilsidesætter reglen.

${ }^{83}$ Jf. det danske Forsikringsankencevnets sag 63.323 og sag 63.823. Begge sager omtales uddybende nedenfor under 4.7.2.

${ }^{84}$ Dvs. det tidspunkt, hvor forsikringsselskabet har de fornødne oplysninger til vurdering af forsikringsbegivenheden.

${ }_{85}^{85}$ Jf. den danske FAL $\S 24$, den svenske FAL kap. 7 § 1, den norske FAL § 8-4, den finske FAL $\S 70$ og den islandske FAL $\S 50$.

${ }^{86}$ Jf. fx det danske Forsikringsankenævnets sag 62.570 .
} 


\subsubsection{Tillcegsforsikringsydelsen kontra køberetlige mangelsbeføjelser og garantibeføjelser}

Med forbehold for det forhold, at selvrisikobeløb i indboforsikringer ofte synes at være noget større end de selvrisikobeløb, der er fastsat i tillægsforsikringer, synes der ikke at være større forskel på erstatningsudmåling i henhold til henholdsvis tillægs- og indboforsikringerne.

Derimod kan der være stor forskel på, hvad forbrugeren kan få ud af henholdsvis tillægsforsikringsdækning og de køberetlige regler. En sammenligning fører til, at det er svært at forestille sig, at forsikringsdækningen, alt andet lige, kan føre til et for forbrugeren bedre resultat end dækningen efter køberetlige regler. Den praktisk væsentligste forskel består i, at tillægsforsikringsvilkårene ofte pålægger forbrugeren at bære en vis selvrisiko med videre, mens de køberetlige regler udelukker, at forbrugerens udøvelse af mangelsbeføjelser betinges af betaling af selvrisiko, og i det hele taget at der påføres forbrugeren udgifter i den forbindelse.

Jf. til illustration det svenske Allmänna Reklamationsnämndens sag 2005-1358 om et videokamera, der var købt for $7.795 \mathrm{kr}$. i december 2000, og som blev totalskadet i december 2004. Erstatning blev fastsat med udgangspunkt i prisen for en ny tilsvarende vare, $5.490 \mathrm{kr}$. Efter aldersnedskrivning på 80 \% (4 x 20) og fradrag af selvrisiko på 100 kr., fik forbrugeren udbetalt 998 kr. Tillægsforsikringens pris i 2000 var $1.095 \mathrm{kr}$.

Hertil kommer, at forbrugeren som udgangspunkt i princippet har krav på, at der sker omlevering, dvs. levering af en ny vare, der fuldt ud opfylder aftalens krav. Se nærmere i det følgende:

I tilfælde af mangler har forbrugeren i overensstemmelse med forbrugerkøbsdirektivets art. 3 som udgangspunkt frit valg mellem at kræve omlevering eller reparation af varen, begge dele uden omkostninger for forbrugeren. Forbrugerens valgfrihed er dog ikke ubegrænset, idet sælgeren kan modsætte sig den af forbrugeren valgte beføjelse, dersom den er umulig eller vil påføre sælgeren uforholdsmæssige omkostninger. Ved afgørelsen heraf tages hensyn til salgsgenstandens værdi uden mangler, mangelens betydning og. om den alternative beføjelse kan gennemføres uden ulempe for køberen. ${ }^{87}$

I det praktiske liv er tegning af tillægsforsikring i hovedsagen begrænset til varige forbrugsgoder, der har en forholdsvis høj pris. For sådanne varers vedkommende fører de anførte regler antagelig temmelig ofte til, at et krav om omlevering som umiddelbar reaktion på en konstateret mangel, vil blive anset for uforholdsmæssigt, og at forbrugeren i første omgang må lade sig nøje med at kræve afhjælpning i form af reparation af varen. Forbrugerens omleveringskrav efter køberetlige regler går ud på, at forbrugeren kan kræve en ny vare, der opfylder kontraktens krav, og ikke blot „en tilsvarende vare“, således som ofte er bestemt i tillægs-

${ }^{87}$ Jf. dansk KBL § 78, stk. 1 og 2, finsk KSL 5.kap. § 18, islandsk FKL § 29, norsk FKPL § 29 og svensk KKPL § 26. 
forsikringerne. I klagenævnspraksis fortolkes tillægsforsikringerne dog således, at der så vidt muligt skal leveres en identisk vare, jf. herved det svenske Allmänna Reklamationsnämndens sag 2005-2832 og det danske Forsikringsankencevnets sag 48.999 og sag 59.937.

Dersom reparation ikke sker inden rimelig tid og uden væsentlig ulejlighed for forbrugeren, kan denne påberåbe sig andre mangelsbeføjelser, herunder forholdsmæssigt afslag, omlevering eller ophævelse af købet. Desuden kan forbrugeren kræve, at sælgeren erstatter udgifterne ved, at reparationen foretages andetsteds. ${ }^{88}$ Ved tillægsforsikringerne kan forbrugeren derimod i almindelighed antagelig næppe opnå mere end en forsikringsdækning, der svarer til dækning af reparationsudgifter (fratrukket eventuel selvrisiko) eller den dækning, forbrugeren efter forsikringsvilkårene er berettiget til i tilfælde af totalskade, jf. herved det danske Forsikringsankencevnets sag 54.960.

Ved ophævelse skal der ske tilbagegivelse af de udvekslede ydelser. Dette indebærer, at køberen har krav på tilbagebetaling af købesummen uden nedskrivning i stil med den, der ofte forekommer i henhold til tillægsforsikringsvilkår.

Efter omstændighederne kan der dog også ud fra køberetlige regler blive tale om at gøre fradrag i forbrugerens tilbagebetalingskrav ud fra det synspunkt, at forbrugeren bør afgive den berigelse, som han eller hun har haft ved varens brug, udmålt som et rimeligt vederlag, for væsentlig nytte. ${ }^{89}$ Ved de forbrugsgoder, som der typisk tegnes tillægsforsikring for, synes det i praksis kun undtagelsesvis at komme på tale at reducere forbrugerens tilbagebetalingskrav ved ophævelse med et skønsmæssigt vederlag for brug. ${ }^{90}$

Forbrugerens beføjelser i henhold til produktgarantier, afhænger af en fortolkning af den enkelte garanti. De i praksis forekommende produktgarantier er imidlertid opbygget om beføjelserne reparation og omlevering, og fortolkes i almindelighed i overensstemmelse med købelovgivningens tilsvarende regler.

Ved en sammenligning af tillægsforsikringsydelsen og forbrugerens garantibeføjelser tegner sig således stort set samme billede som det, der er skitseret ovenfor om forholdet mellem tillægsforsikringsydelsen og de køberetlige mangelsbeføjelser.

\footnotetext{
${ }^{88}$ Se nærmere dansk KBL § 78, stk. 4 , finsk KSL 5.kap. § 20, Islandsk FKL § 33, norsk FKPL § 33 og svensk KKPL § 28.

${ }^{89}$ Jf. således islandsk FKL $\S 50$ og norsk FKPL $\S 50$. Lignende bestemmelse findes i svensk KKPL § 44. I Danmark er spørgsmålet ikke lovreguleret, men berigelseskrav kan efter omstændighederne pålægges efter ulovbestemte principper.

${ }^{90}$ Se nærmere betænkning 1403/2001 om gennemførelse af forbugerkøbsdirektivet s. $128 \mathrm{ff}$. om dansk klagenævnspraksis. Se til illustration det norske Forbrukertvistutvalgets sak 20030494, hvor sælgeren ved forbrugerens reklamation over et mangelfuldt køle/fryseskab, som havde været i brug i godt 2 år, ville gøre et fradrag på $10 \%$ af købesummen pr. brugsår. Med henvisning til karakteren af de problemer, forbrugeren havde haft med køle/fryseskabet, fandt Forbrukertvistutvalget ikke, at forbrugeren havde haft en sådan "vesentlig nytte" af køle/fryseskabet, at det kunne begrunde fradrag i tilbagebetalingskravet ved ophævelse.
} 


\subsection{Sammenfatning: Hvad opnår forbrugeren ved tillægsforsikringen?}

\subsubsection{Fordele ift. beskyttelsen efter købeloven og en eventuel garanti}

Tillægsforsikringens værdi for forbrugeren „begrænses“ i alle tilfælde af køberetlige regler om mangler og i det praktiske liv desuden normalt af indboforsikringsdækningen. Afhængig af de nærmere forhold begrænses tillægsforsikringens værdi herudover af eventuelle særlige garantitilsagn, afgivet af sælgeren eller varens producent eller lignende, for den pågældende vare. Den omstændighed, at værdien af en tillægsforsikring i realiteten kan være meget beskeden, øger betydningen af den information, detailforretningen giver forbrugeren ved købet af tillægsforsikringen. De informationskrav og andre krav i forbindelse med tillægsforsikringer, der følger af lovgivningen, gennemgås nedenfor i kapitel 4.

Sammenligningen af de i praksis forekommende tillægsforsikringer og køberetlige regler om mangler kan sammenfattes i, at tillægsforsikringerne typisk ikke giver forbrugeren større tryghed i tilfælde af kvalitetssvigt end de køberetlige regler, før end der er forløbet en vis længere tid efter købet. Hvor lang tid der herved kommer på tale, beror i første række på varens karakter. Den „mertryghed“, der kan komme på tale, kan bestå i:

(a) at tillægsforsikringstiden er længere end købelovgivningens absolutte reklamationsfrist, dvs. to år (Danmark), 3 år (Sverige), 5 år (efter omstændighederne dog kun to) år (Island og Norge); i Finland er der slet ingen absolut reklamationsfrist, se nærmere under 3.2.1.

(b) I kraft af tillægsforsikringen kan forbrugeren, når der er gået mere end seks måneder efter leveringen, alt efter omstændighederne opnå en vis bevismæssig fordel bestående $\mathrm{i}$, at relevant faktuel tvivl med hensyn til årsagen til funktionssvigt med videre juridisk kommer forbrugeren til gode, se nærmere under 3.1.1.

Forbrugeren opnår dog ikke den mertryghed, der følger af det under (a) og (b) anførte, i det omfang varen er omfattet af sælgerens eller tredjemands garantitilsagn, se nærmere under 3.1.2 og 3.2.2.

Desuden skal man ved en nærmere vurdering af de fordele, der efter det anførte kan være forbundet med en tillægsforsikring, være opmærksom på, at forsikringsdækningen normalt ikke står mål med den „dækning“, forbrugeren kan opnå efter køberetlige regler. Dette beror dels på, at tillægsforsikringerne ofte indeholder regler om selvrisiko, nedskrivning med videre samt det forsikringsretlige berigelsesforbud, se nærmere under 3.3.

(c) De begivenheder, der kan udløse tillægsforsikringsdækning, omfatter i nogle, men ikke alle tilfælde, i et vist omfang også udefra 
kommende begivenheder indtruffet efter risikoens overgang til forbrugeren (uden at det skyldes, at sælgeren har tilsidesat sine forpligtelser efter aftalen). Dette er en fordel for brugeren, i den udstrækning sådanne begivenheder ikke er omfattet af forbrugerens indboforsikring med videre.

\subsubsection{Fordele ift. en eventuel indboforsikring}

Indboforsikringers typiske dækningsområder er brand- og vandskader, tyveri og hærværk, dvs. udefra kommende begivenheder, der forårsager beskadigelse eller ødelæggelse af tingen. Tillægsforsikringers typiske dækningsområde er derimod funktionsfejl, nedbrud og lignende, dvs. fejl ved selve tingen. I udgangspunktet overlapper de to typer af forsikringer således ikke hinanden.

Dette billede ændres imidlertid ofte i praksis som følge af de mange tilvalgsmuligheder, såvel indbo- som tillægsforsikringer rummer. Som omtalt under 3.1.2 giver mange indboforsikringer mulighed for, ved betaling af en forhøjet præmie, at udvide dækningen til også at gælde skader på tingen, der skyldes udefra kommende forhold, herunder husstandens egen adfærd. Her vil der således være overlap i forhold til en (typisk udvidet) tillægsforsikring, der i en vis udstrækning også dækker skader forvoldt ved bl.a. forbrugerens egen adfærd. Endvidere dækker mange udvidede tillægsforsikringer også tyveri. Her vil der ligeledes være tale om et dækningsområde, der til dels overlapper de fleste almindelige indboforsikringer.

Som beskrevet viser klagenævnspraksis, at de almindelige forsikringsretlige principper, der følger af FAL, herunder vedrørende erstatningsgrundlag og -opgørelse, også finder anvendelse for tillægsforsikringer. Dette bidrager for det første til at udviske forskellen mellem indbo- og tillægsforsikringer. For det andet indebærer det, at en tillægsforsikring, der er uklart affattet, vil blive fortolket i overensstemmelse med de almindelige forsikringsretlige principper. Dette kan indebære en skuffelse for den forbruger, der for eksempel læser en given tillægsforsikring således, at forsikringen - hvis den udløses - giver forbrugeren ret til at få den fulde købesum tilbage, og ikke kun produktets forsikringsretlige genanskaffelsesværdi.

Sammenfattende må det om forholdet mellem tillægsforsikringer og indboforsikringer konstateres, at der om end ikke i udgangspunktet, så dog konkret kan - og i mange tilfælde vil - være tale om overlappende dækningsområder. Det gælder navnlig i relation til tillægsforsikringer, der ikke kun dækker funktionsfejl o.lign., men også tyveri og andre „udefra kommende begivenheder“, hændelige uheld med videre. I disse tilfælde giver en tillægsforsikring altså ikke, eller kun i et beskedent omfang, en udvidet beskyttelse i forhold til indboforsikringen og den relativt store udgift til en tillægsforsikring kan for så vidt siges at være mere eller min- 
dre spildt. Selv om en tillægsforsikrings dækningsområde overlapper det, der følger af en indboforsikring, bør man være opmærksom på, at eventuelle selvrisikobeløb i indboforsikringer ofte synes at være noget større end de selvrisikobeløb, der hyppigt forekommer i tillægsforsikringer. 



\section{Forbrugerbeskyttelse ved tegning og aktivering af tillægsforsikringer}

I kapitel 2 blev markedet for tillægsforsikringer beskrevet, herunder salgsprocessen i detailforretningen, der bl.a. er kendetegnet ved, at beslutning om tegning af en tillægsforsikring normalt skal træffes af forbrugeren i selve forretningen, i løbet af et meget lille tidsrum og i det væsentlige på baggrund af de informationer, som ekspedienten giver.

I kapitel 3 er beskrevet, hvilke fordele en tillægsforsikring giver forbrugeren henset til forbrugerens automatiske minimumsbeskyttelse efter købelovgivningens beskyttelsespræceptive regler om mangler, eventuelle supplerende produktgarantier og forbrugerens (eventuelle)91 indboforsikring.

Det blev i den forbindelse konkluderet, at tillægsforsikringerne typisk ikke giver forbrugeren større tryghed i tilfælde af kvalitetssvigt end de køberetlige regler, før der er forløbet en vis længere tid efter købet, at den „mertryghed“, der herefter kommer på tale, alligevel ikke er reel, i den udstrækning varen er omfattet af en længerevarende produktgaranti, og at nogle tillægsforsikringer, nemlig sådanne, som dækker udefra kommende hændelser, i et vist omfang giver forbrugeren en dækning, som går videre end den, der ofte er forbundet med en indboforsikring; forbedringen på dette punkt afhænger dog i høj grad af den konkrete tillægsforsikrings udformning og det nærmere indhold af forbrugerens (eventuelle) indboforsikring.

Den enkelte forbruger kan således efter omstændighederne have vanskeligt ved at fastslå, hvilket tillæg forsikringen reelt yder til den beskyttelse, forbrugeren i forvejen nyder godt af. De særlige omstændigheder, hvorunder tillægsforsikringerne sælges i detailleddet, nemlig som et accessorium til den pågældende vare, er egnet til at forstærke forbrugerens vanskeligheder i så henseende.

På denne baggrund redegøres i det følgende for, i hvilket omfang den gældende lovgivning beskytter forbrugerens interesser i forbindelse med tegning og aktivering af tillægsforsikringer.

Under 4.1 behandles først nogle mellemmandsretlige aspekter i forbindelse med tegningen af tillægsforsikringer. Dernæst ses på de regler, som skal medvirke til, at forbrugerens tegning kan ske på et forsvarligt grundlag, jf. 4.2, mens fremstillingen under 4.3 angår de retlige konse-

${ }^{91}$ Som nævnt i kapitel 3 har langt den overvejende del af forbrugerne i de nordiske lande tegnet indboforsikring mv. 
kvenser af brist i forbrugerens beslutningsgrundlag. Under 4.4 omtales spørgsmålet om forbrugerens fortrydelsesret. Da forbrugeren i tillægsforsikringssammenhæng spiller en dobbeltrolle som køber og forsikringstager, er det nærliggende at komme nærmere ind på spørgsmålet om det eventuelle samspil mellem de køberetlige og de forsikringsretlige beskyttelsesregler, jf. 4.5.

Som nævnt en passant flere steder i kapitel 3 kan visse af de vilkår, der anvendes i de indhentede tillægsforsikringer forekomme problematiske, når de ses fra et forbrugerbeskyttelsessynspunkt. Dette gælder bl.a. vilkår om tillægsforsikringers førtidige ophør, som omtales under 4.6. Spørgsmålet om visse andre muligt vildledende og/eller indholdsmæssigt urimelige vilkår omtales under 4.7

Kapitel 4 giver grundlaget for kapitel 5, hvor det vurderes, hvorvidt den beskrevne forbrugerbeskyttelse kan anses for tilstrækkelig og, i benægtende fald, hvilke retspolitiske tiltag der i givet fald kan komme på tale.

\subsection{Mellemmandsretlige spørgsmål}

\subsubsection{Detailforretningens aftaleretlige status}

Som omtalt i kapitel 2 tegnes tillægsforsikringerne i detailforretningen i forbindelse med køb af det fysiske produkt (hovedproduktet), som forsikringen skal dække. Kontraktforholdet mellem forbrugeren og forsikringsselskabet etableres således med detailforretningen som mellemmand. I det omfang forsikringsselskabet har givet detailforretningen mandat til at indgå aftaler om tillægsforsikringer i forsikringsselskabets navn og for dettes regning (hvilket synes at være den almindelige praksis på området), foreligger der et fuldmagtsforhold mellem forsikringsselskabet og detailforretningen. Det er således forsikringsselskabet, der er forbrugerens aftalepart, og som umiddelbart forpligtes og berettiges over for forbrugeren af detailforretningens aftale inden for fuldmagtens grænser.

I de fleste tilfælde synes forsikringsselskaberne at anvende detailforretningerne ikke alene som salgskanal, men også som skadebehandlere. Detailforretningens fuldmagt til at handle på forsikringsselskabets vegne synes således normalt at omfatte dels indgåelsen af aftalen om tillægsforsikringsdækning dels modtagelse og behandling af skadesanmeldelse. ${ }^{92}$

Så længe detailforretningen handler inden for fuldmagten (legitimationen), forpligtes forsikringsselskabet umiddelbart af forretningens retlige dispositioner over for forbrugeren. Dette gælder også, selv om forretningen herved måtte handle i strid med de retningslinier, forsikringsselskabet har afstukket for detailforretningen, hvis denne dog har holdt sig inden fuldmagten, forudsat at forbrugeren hverken vidste eller burde vide, at forretningen handlede i strid med retningslinjerne.

\footnotetext{
${ }^{92}$ Se fx bilag 2.1, bilag 2.2, bilag 2.3 og bilag 2.6.
} 
Jf. herved det danske Forsikringsankencevnets sag 52.988 vedrørende en pc-forretning, der udbød tillægsforsikringer på vegne af et forsikringsselskab. En forbruger, der havde købt en pc og samtidig tegnet en 5-årig tillægsforsikring, aktiverede forsikringen, da pc'en efter 4 år gik i stykker. Forretningen misforstod forsikringens vilkår vedrørende opgørelse af forsikringssum og indgik en aftale med forbrugeren, der stillede denne bedre, end forsikringspolicen gav hjemmel til. Forsikringsankenævnet fastslog, at forsikringsselskabet som udgangspunkt var bundet af de aftaler, som detailforretningen indgik med forsikringstagere i forbindelse med forsikringstegning og skadebehandling.

I det norske Forsikringsskadenemndas sag 2560 blev forbrugerens mobiltelefon stjålet, inden han modtog forsikringsbeviset. Forbrugeren gjorde gældende, at han ikke ved tegningen var gjort bekendt med de dækningsbegrænsninger, som fremgik af forsikringsbeviset, og at han hvis han havde været bekendt med dem - ikke ville have været interesseret i tillægsforsikringen. Nævnet fastslog at detailforretningen ikke havde haft fuldmagt til at tegne forsikringen på andre end selskabets normale vilkår, og at forbrugeren ikke havde grund til at regne med bedre dækning end den, der fulgte heraf.

Ved at anvende detailforretningen som salgskanal hæfter forsikringsselskabet efter almindelige erstatningsretlige principper over for forbrugeren for forretningens culpøse, erstatningspådragende adfærd i forbindelse med hvervets udførelse, jf. således det danske Forsikringsankencevnets sag 50.739. ${ }^{93}$

Når detailforretningen optræder som fuldmægtig, ifalder den erstatningsansvar over for forbrugeren, dersom denne ikke opnår den tilsagte ret over for forsikringsselskabet, jf. § 25 i de fællesnordiske aftalelove. Dette erstatningsansvar, der ifaldes på objektivt grundlag, forudsætter, at forbrugeren er i god tro, og kan begrunde erstatning udmålt til forbrugerens positive opfyldelsesinteresse.

Jf. herved det danske Forbrugerklagencevnets sag 1996-441/7-17, ${ }^{94}$ hvor forbrugeren ved køb af en vaskemaskine mod betaling af en forsikringspræmie på $425 \mathrm{kr}$. havde tegnet en forsikring på 5 års service. Da forbrugeren tre år efter købet ville udnytte forsikringen, viste det sig, at sælgeren ikke havde indsendt forsikringspapirerne og betalt præmien. Forsikringsselskabet afviste derfor at betale en regning på 687 kr. for reparation af vaskemaskinen. ${ }^{95}$ Forbrugeren indbragte sagen for Forbrugerklagenævnet med krav om vederlagsfri afhjælpning.

\footnotetext{
${ }^{93}$ Sagen er omtalt nærmere nedenfor under 4.3.

${ }^{94}$ Forbrugerstyrelsens Juridiske Årbog 1997 s. 87.

${ }^{95}$ Sagsreferatet oplyser ikke, hvad der var baggrunden for forsikringsselskabets manglende vilje til at dække (manglende fuldmagt?). Det bemærkes herved, at forsikringsselskabet ikke var medindklaget for Forbrugerklagenævnet, som ikke kan behandle forbrugerklager angående forsikring. Sådanne sager henhører i Danmark under Forsikringsankenævnet. En sådan kompetencefordeling, som også kendes i Norge (Forbrukertvistutvalget og Forsikringsskadenemnda) kan have mange fordele, men kan også i sager angående tillægsforsikirnger efter omstændighederne føre til en uheldig opsplitning af klagebehandlingen.
} 
Under sagens behandling viste det sig, at leverandøren havde betalt for reparationen, således at forbrugeren var holdt skadesløs. Forbrugeren krævede imidlertid sagen forelagt Forbrugerklagenævnet, idet hun bl.a. krævede, at detailforretningen tilbagebetalte forsikringspræmien på 425 kr. Nævnet bemærkede, at forbrugeren ved indgivelse af klage til Forbrugerklagenævnet havde fremsat krav om gratis reparation af en fejl, som ville være dækket af forsikringen, dersom sælgeren havde opfyldt aftalen. Dette krav havde forbrugeren fået opfyldt, og hun kunne derfor ikke samtidig ophæve aftalen om forsikringen og få hele forsikringspræmien tilbagebetalt.

\subsubsection{Detailforretningen som forsikringsformidler}

Aftalelovgivningens almindelige fuldmagtsregler indeholder ikke særlige forbrugerbeskyttelsesregler i relation til kontraktindgåelsen mellem fuldmægtig (her forretningen) og tredjemand (forbrugeren). Særlige regler, der skal beskytte forsikringstagere ved forsikringsformidling, følger derimod af direktiv 2002/92/EF om forsikringsformidling, der er implementeret $\mathrm{i}$ alle de nordiske lande. ${ }^{96}$

Direktivet har til formål at samordne medlemsstaternes bestemmelser om faglige kvalifikationskrav til og registrering af personer, der optager og udøver forsikringsformidling, for derved at bidrage til virkeliggørelsen af det indre marked for finansielle tjenesteydelser og til forbedring af forbrugerbeskyttelsen på dette felt. ${ }^{97}$

Spørgsmålet er imidlertid, om detailforretninger, der formidler tillægsforsikringer, overhovedet kan anses for forsikringsformidlere i direktivets forstand

Ved forsikringsformidling forstås ifølge direktivet „virksomhed, der består i at forelægge, foreslå eller udføre det indledende arbejde i forbindelse med indgåelse af forsikringsaftaler eller at indgå sådanne aftaler eller at medvirke ved administrationen og opfyldelsen af sådanne aftaler, navnlig i skadestilfælde“, jf. artikel 2, nr. 3.

Direktivet fastsætter en række krav til virksomheder og personer, der udøver forsikringsformidlingsvirksomhed. Kravene omfatter bl.a. registrering hos en kompetent myndighed i formidlerens hjemland og krav til viden om og uddannelse inden for forsikringsformidling. ${ }^{98}$ Endvidere fastsætter direktivet en række oplysningsforpligtelser over for kunden i forbindelse med formidlingen.

\footnotetext{
${ }^{96}$ I Danmark ved lov om forsikringsformidling (lovbekendtgørelse nr. 767 af 5 august 2005 om forsikringsformidling, herefter forsikringsformidlingsloven). I Finland er direktivet implementeret ved lag 570/2005, i Norge i lov 41/2005 og i Sverige ved lag 2005:405. Island har gennemført regler svarende til direktivets ved lov 32/2005, som efter det for udrederne oplyste kun foreligger på islandsk.

${ }^{97}$ Jf. direktivets betragtning 8 . Sml. § 1, stk. 1, i den danske lov, § 1 i den svenske, § 1-2 i den norske samt $\S 1$ i den finske.

${ }^{98}$ Disse krav er i dansk ret gennemført ved bekendtgørelse 1110/2004 om forsikringsformidleres uddannelse (uddannelsesbekendtgørelsen).
} 
Forsikringsformidlingsdirektivet finder anvendelse på erhvervsmæssig formidling af forsikringer. En række typer af forsikringsformidling er dog udtrykkeligt undtaget fra direktivets anvendelsesområde, jf. artikel 1, stk. 2, og artikel 2, nr. 3 og 4.

Efter artikel 2, nr. 3 og 4 finder direktivet ikke anvendelse, hvor en virksomhed lejlighedsvis rådgiver om forsikring i forbindelse med udøvelse af anden erhvervsvirksomhed, når hovedformålet med rådgivningen ikke er at bistå kunden med at forelægge, foreslå, indgå eller udføre det indledende arbejde i forbindelse med indgåelse af en forsikringsaftale.

Idet salg af tillægsforsikringer utvivlsomt er subsidiært i forhold til detailforretningernes hovedvirksomhed (salg af diverse forbrugerprodukter), kan man overveje, om formidling af tillægsforsikringer er omfattet af denne undtagelse fra direktivet. Dette er dog ikke tilfældet. Som det fremgår af direktivet (og betragtningerne til dette), er det en betingelse for at anvende undtagelsen, at hovedformålet med rådgivningen ikke er at bistå kunden aktivt med at indgå eller opfylde en forsikringsaftale. Idet såvel indgåelse af aftalen om tegning af tillægsforsikringen som betalingen for denne sker i detailforretningen under aktiv bistand fra og rådgivning af salgspersonalet, er denne betingelse ikke opfyldt. Tillægsforsikringer falder derfor allerede af denne grund ${ }^{99}$ ikke ind under undtagelsen i artikel 2, nr. 3 og 4.

Efter forsikringsformidlingsdirektivets artikel 1, stk. 2, finder direktivet ikke anvendelse på formidling af forsikringsprodukter, der opfylder alle følgende betingelser:

a) Forsikringsaftalen forudsætter kun viden om den forsikringsdækning, der tilbydes.

b) Forsikringsaftalen er ikke en livsforsikringsaftale.

c) Forsikringsaftalen omfatter ingen ansvarsdækning.

d) Den pågældende person udøver ikke forsikringsformidling som hovederhverv.

e) Forsikringen udgør et supplement til det produkt eller den tjenesteydelse, som leveres af en given leverandør, såfremt forsikringen dækker

i) risiko for driftsfejl ved tab eller beskadigelse af varer leveret af den pågældende leverandør eller

ii) tab eller beskadigelse af bagage og andre risici i tilknytning til en rejse bestilt hos den pågældende leverandør, uanset om forsikringsaftalen omfatter livs- eller ansvarsforsikring, forudsat at dækningen er accessorisk i forhold til hoveddækningen vedrørende risici i tilknytning til denne rejse.

\footnotetext{
${ }^{99}$ Hertil kommer, at bestemmelsens krav om, at der (kun) skal være tale om lejlighedsvis rådgivning i de fleste tilfælde næppe heller kan anses for opfyldt ved tillægsforsikringer. Det skyldes, at forsikringsrådgivning, i hvert fald efter det danske Finanstilsynets praksis, ikke kan betegnes som "lejlighedsvis”, hvis rådgivningen tilbydes som et fast forretningskoncept og som en del af hovedaktiviteten, hvilket som regel er tilfældet ved salg af tillægsforsikringer.
} 
f) Det årlige præmiebeløb overstiger ikke 500 euro, og forsikringens løbetid inklusive forlængelser overstiger ikke fem år.

Af direktivet fremgår, at undtagelsesbestemmelsen sigter mod tilfælde, hvor udbud af forsikringsaftaler er et accessorium til den erhvervsdrivendes hovedvirksomhed. Da udbud af tillægsforsikringer utvivlsomt er et accessorium til detailforretningernes salg af forbrugerprodukter, er spørgsmålet, om samtlige undtagelsesbestemmelsens øvrige betingelser generelt er opfyldt for tillægsforsikringers vedkommende.

Ifølge artikel 1, stk. 2, litra a, er det en betingelse (for at undtagelsen kan finde anvendelse), at forsikringsaftalen kun forudsætter viden om det pågældende forsikringsprodukt, der tilbydes. Taget på ordene er denne betingelse ikke helt let at blive klog på (hvornår forudsætter en aftale viden om mere end det, aftalen går ud på? Og hvornår gør den det ikke?). Den bagvedliggende tanke må imidlertid antages at være, at den, der formidler forsikringen, ikke behøver at have en generel viden om forsikringsforhold, men vel om den formidlede aftales indhold. Bestemmelsen bidrager dog ikke til en nærmere afgrænsning heraf i form af antydning af en målestok for, hvornår generel forsikringsretlig viden er nødvendig. Et fingerpeg i retning af, at der bl.a. er tænkt på tillægsforsikringer ved varekøb, findes dog i den under litra e, nævnte betingelse, som imidlertid nærmest synes at overflødiggøre litra a.

Stk. 2, litra d, fastslår det ovenfor nævnte overordnede princip om, at forsikringsformidlingen skal være en accessorisk aktivitet i forhold til den erhvervsdrivendes hovedvirksomhed. Ifølge forarbejderne følger det tillige af denne betingelse, at der skal være tale om forsikringsprodukter, der af natur er mindre komplicerede. Disse betingelser må ligeledes siges at være opfyldt for tillægsforsikringers vedkommende.

Stk. 2, litra b og c er også umiddelbart opfyldt, idet en tillægsforsikring ikke er en livsforsikringsaftale og heller ikke omfatter ansvarsdækning. Idet tillægsforsikringen udgør et supplement til selve hovedproduktet og dækker risiko for driftsfejl, er også stk. 2, litra e, nr. i opfyldt. Endelig er det en betingelse, at forsikringsaftalens årlige præmiebeløb ikke overstiger 500 euro, ${ }^{100}$ og at forsikringens løbetid, inklusive forlængelser, ikke overstiger 5 år, stk. 2, litra f. Disse betingelser synes også at være opfyldt for de i praksis forekommende tillægsforsikringers vedkommende.

Samlet må det fastslås, at langt hovedparten af, om ikke alle, ${ }^{101}$ de tillægsforsikringer, der forekommer i praksis er undtaget fra forsikringsformidlingsdirektivet i medfør af dettes artikel 1, stk. 2 .

I relation til kravene vedrørende oplysning til forbrugeren er direktivet et minimumsdirektiv, der giver medlemsstaterne mulighed for at opretholde eller indføre strengere bestemmelser, jf. artikel 12, stk. 5. Det inde-

\footnotetext{
${ }^{100}$ Svarende til ca. 3750 DKK.

${ }^{101}$ Det er da også forståeligt og forventeligt, at de eksisterende tillægsforsikringer helt bevidst er udformet således, at de ikke er omfattet af de krav, der stilles til de forsikringsformidlere, der er omfattet af direktivet.
} 
bærer, at medlemsstaterne kan beslutte, at forsikringsformidlere, der ikke i øvrigt omfattes af direktivet (og den nationale gennemførelseslov), skal være omfattet af oplysningskravene.

Af de nordiske lande har kun Danmark benyttet sig af denne mulighed. Det fremgår således af den danske forsikringsformidlingslov $\S 3$, stk. 3 , at forsikringsdistributører, der ikke opfylder betingelserne i $\S 3$, stk. 2 (svarende til direktivets artikel 1, stk. 2) desuagtet skal opfylde de oplysningskrav, der følger af lovens $\S 34$. Ved forsikringsdistributørvirksomhed forstås den aktivitet, der består i efter aftale med et eller flere forsikringsselskaber at formidle forsikringsselskabets produkter. Der er næppe tvivl om, at detailforretninger, der formidler tillægsforsikringer, må anses for forsikringsdistributører efter $\S 3$, stk. 3, og således omfattes af oplysningskravene i den danske lovs $\S 34$.

\subsection{Forbrugerens beslutningsgrundlag}

Forbrugerens beslutning om at tegne tillægsforsikring i forbindelse med varekøb træffes på grundlag af forbrugerens viden og forestillinger om risiko- og dækningsforhold. Som udgangspunkt er det forbrugerens egen sag at skaffe sig et tilstrækkeligt grundlag for beslutningen. I et vist omfang påhviler det dog forsikringsselskabet og/eller detailforretningen at sørge for, at forbrugeren modtager et vist minimum af information af betydning for forbrugerens beslutning.

Som nævnt under 4.1.2 er detailforretninger, der formidler forsikringer, ikke omfattet af direktivet om forsikringsformidling. Imidlertid udstrækker den danske (men ikke de øvrige nordiske landes) gennemførelseslovgivning direktivets oplysningskrav ud over direktivets anvendelsesområde, således at det også omfatter detailforretningers formidling af tillægsforsikringer i forbindelse med varekøb. Den danske forsikringsformidlingslovs § 34 er sålydende:

\footnotetext{
„Stk. 1. Senest samtidig med, at en konkret forsikringsaftale indgås, skal forsikringsagentvirksomheden eller administrationsselskabet give kunden information om forsikringsaftalens primære indhold. Der skal som minimum gives information om:

1. relevante rettigheder i henhold til købeloven,

2. mulige andre forsikringsdækninger,

3. forsikringsaftalens dækningsomfang,

4. forsikringsaftalens løbetid,

5. betingelser for opsigelse af forsikringsaftalen, og

6. hvilke bestemmelser, der gælder for behandling af klager fra kunden vedrørende aftalen, herunder om der findes en klageinstans.
}

Stk. 2. Modtager forsikringsagentvirksomheden eller administrationsselskabet provision eller andet vederlag som følge af forsikringsformidlingen, skal kunden gøres bekendt hermed. Endvidere skal forsikringsagentvirksomheden eller administrationsselskabet gøre kunden bekendt med adgangen til at få oplyst provisionens eller vederlagets størrelse og på forespørgsel oplyse denne.“ 
Forsikringsformidlerens oplysningspligt efter $\S 34$ omfatter en række oplysninger, der er særlig relevante i relation til tillægsforsikringer, herunder navnlig kravet om, at der skal oplyses om relevante rettigheder i henhold til købeloven og om mulige andre forsikringsdækninger. Også kravet i stk. 2 om, at kunden, såfremt formidleren modtager provision for formidlingen, skal gøres bekendt med dette, og at kunden skal oplyses om, at denne på forespørgsel kan få oplyst størrelsen på provisionen, har betydning ved formidling af tillægsforsikringer.

Efter § 35 skal de i § 34 angivne oplysninger gives på en tydelig og nøjagtig måde, der er forståelig for kunden og på dansk, medmindre andet er aftalt. Finanstilsynet kan fastsætte nærmere regler om, hvorledes oplysninger skal meddeles kunden.

Sådanne regler er fastsat i bekendtgørelse 1114/2004 om forsikringsformidleres informationspligt. Bekendtgørelsen gentager i det væsentlige oplysningskravene i lovens $\S 34$, men uddyber i et vist, beskedent omfang lovens beskrivelse af kravene til oplysningernes indhold, bl.a. ved at stille krav om oplysning om, „hvorledes forsikringsaftalen giver dækning ud over købelovens regler om mangelsbeføjelser“, i de tilfælde, hvor forsikringen dækker „,skader på produktet“, jf. bekendtgørelsens § 4, stk. 3 .

Desuden foreskriver bekendtgørelsen i § 2, stk. 2, jf. § 4, stk. 1, at oplysninger skal gives skriftligt til kunden i form af et dokument, der så vidt muligt skal udleveres inden forsikringsaftalens indgåelse. ${ }^{102}$ Det er ikke et krav, at oplysningerne gives i et særskilt dokument. ${ }^{103}$ De kan således være en integreret del af forsikringsvilkårene.

De øvrige nordiske lande ses ikke at have tilsvarende specifikke lovbestemmelser ${ }^{104}$ om detailforretningers oplysningspligt ved formidling af tillægsforsikringer i forbindelse med varekøb.

De øvrige nordiske landes forsikringsaftalelovgivning indeholder derimod almindelige informationskrav til forsikringsselskaberne; i Danmark opstiller forsikringsaftaleloven ikke informationskrav, som kan måle sig med dem, der følger af de øvrige nordiske landes langt nyere forsikringsaftalelove.

Den norske FAL § 2-1 fastslår i relation til skadesforsikring, at forsikringsselskabet skal sætte forbrugeren i stand til at vurdere forsikringstilbudet, herunder oplyse om „alternative dækningsformer“. Heraf må følge, at en udbyder af tillægsforsikringer er forpligtet til at oplyse forbrugeren om, at denne efter omstændighederne kan være dækket via sin indboforsikring. Pligten må selvsagt også gælde, når forsikringen formidles via en tredjemand - for tillægsforsikringers vedkommende en detailforretning.

\footnotetext{
${ }^{102}$ Indgås forsikringsaftalen via Internettet, kan oplysningerne dog gives via forsikringsformidlerens hjemmeside.

${ }^{103}$ Som eksempel på, at oplysningerne gives i et særskilt dokument, henvises til bilag 2.4.

${ }^{104}$ I de svenske retningslinier for information om visse forbrugerforsikringer, KOVFS 2001:5, findes dog under punkt 2.4.3 specifik soft law regulering angående tillægsforsikringerne. Se nærmere teksten nedenfor.
} 
Efter den svenske FAL kap. 2 (om skadesforsikringer) § 2, skal forsikringsselskabet, forinden en forbrugerforsikringsaftale indgås, „lämne information som underlätter kundens bedömning af försäkringsbehovet och val av försäkring. Informationen skall på ett enkelt sätt återge det huvudsakliga innehållet i de försäkringsvillkor som kunden behöver ha kännedom om för at kunne bedömma kostnaden för och omfattningen av försäkringen“. Efter denne bestemmelse, der ligeledes må gælde ved salg af tillægsforsikringer gennem detailhandlen, må det påhvile forsikringsselskabet at give forbrugeren oplysning om købelovens reklamationsregler ved mangler og den omstændighed, at kundens behov for en tillægsforsikring desuden kan påvirkes af en eventuel indboforsikring.

Den svenske FAL kap. $2 \S 3$ indeholder en undtagelse til § 2, idet $\S 3$ fastslår, at oplysningspligten efter $\S 2$,behöver inte lämnas i den mån kunden avstår från den eller möter hinder med hänsyn till förhållandene då försäkringsavtalet ingås“. Betingelserne for at anvende $\S 3$ i forbindelse med salg af tillægsforsikringer vil i almindelighed ikke være opfyldt. Forsikringsselskabet - i praksis via detailforretningen - må således som klar hovedregel skulle opfylde sin oplysningspligt efter FAL § 2 ved salg af tillægsforsikringer.

Det svenske Konsumentverket har udarbejdet retningslinier om information om visse forbrugerforsikringer (KOVFS 2001:5 af 10. december 2001). Retningslinierne knytter sig til informationsforpligtelserne i FAL samt den svenske markedsføringslov. Retningslinierne indeholder bl.a. under punkt 2.4.3 forskrifter, der specifikt tager sigte på detailforretningers markedsføring af tillægsforsikringer i forbindelse med varekøb, og bestemmer, at der skal informeres om, i hvilken udstrækning forsikringen omfatter samme beskyttelse, som følger af lov og en eventuel garanti.

I lighed med den svenske og norske FAL fastslår den finske FAL § 5, at forsikringsselskabet, forinden en aftale indgås, skal „ge försäkringssökanden den information som behövs för bedömning av försäkringsbehovet och för valet av försäkring, såsom information om försäkringsformerna, premierna och försäkringsvillkoren“. Også for Finlands vedkommende må der således påhvile udbyderen af en tillægsforsikring (eller en formidler på dennes vegne) at oplyse forbrugeren om den beskyttelse, der allerede følger af de køberetlige reklamationsregler eller en eventuel indboforsikring.

Ifølge den islandske $\mathrm{FAL}^{105} \S 4$ skal forsikringsselskabet (efter den uofficielle engelske oversættelse af loven) „provide the information necessary for the policyholder to evaluate its proposed insurance cover".

Bortset fra et krav om oplysning om forbrugerens fortrydelsesret ${ }^{106}$ samt oplysningskrav i forbindelse med fjernsalg af forsikringsaftaler, ${ }^{107}$ indeholder den danske FAL ingen særlige regler om information til for-

\footnotetext{
${ }^{105}$ Jf. lov nr. 30/2004.

${ }^{106}$ Se nærmere herom under 4.4 .

${ }^{107}$ Se nærmere om fjernsalg under 4.4 .
} 
sikringstageren i forbindelse med indgåelse af en forsikringsaftale. Sådanne oplysningskrav følger imidlertid af regler i anden lovgivning. Det gælder for det første de detaljerede oplysningskrav i forsikringsformidlingslovens $\S 34$ (som omtalt ovenfor). For det andet følger en generel informationsforpligtelse af reglerne om „god skik“ for finansielle virksomheder.

Lov om finansiel virksomhed ${ }^{108} \S 43$, stk. 1 , fastsætter således, at „finansielle virksomheder og finansielle holdingvirksomheder skal drives i overensstemmelse med redelig forretningsskik og god praksis inden for virksomhedsområdet“. Denne finansielle generalklausul omfatter også forsikringsselskabers forsikringer.

Efter $\S 43$, stk. 2, kan økonomi- og erhvervsministeren fastsætte nærmere regler til udfyldning af den finansielle generalklausul i stk. 1. I medfør heraf er udstedt bkg. 1046/2004 om god skik for finansielle virksomheder. Bekendtgørelsens kap. 10 indeholder en række oplysningskrav til forsikringsselskaber. Disse oplysningskrav må antages også at gælde, selv om forsikringen - som for tillægsforsikringers vedkommende - formidles af en tredjemand, jf. princippet i bekendtgørelsens $\S 2$, hvorefter en finansiel virksomhed, der indgår aftale med andre finansielle virksomheder om afsætning og rådgivning i forbindelse med virksomhedens produkter, skal sikre sig, at medkontrahenten overholder reglerne i bekendtgørelsen.

Ifølge bekendtgørelsens $\S 5$, stk. 2, skal en finansiel virksomhed, herunder et forsikringsselskab, yde rådgivning „hvor omstændighederne tilsiger, at der er behov herfor“. § 26, stk. 3, præciserer, at „et forsikringsselskab skal oplyse kunden om risikoen for dobbeltforsikring på skadesforsikringsområdet“. Efter disse bestemmelser må et forsikringsselskab, der via detailleddet sælger tillægsforsikringer, være forpligtet til at sikre, at forbrugeren oplyses om, at det konkrete behov for en tillægsforsikring bl.a. kan afhænge af, om der er tegnet en indboforsikring.

Samtlige ovennævnte oplysningsforpligtelser er af (overvejende) offentligretlig karakter, idet de kan udløse enten bødestraf eller fremadrettede forbud eller påbud.

Overtrædelse af den danske forsikringsformidlingslov ${ }^{109}$ og den omtalte bekendtgørelse 1114/2004 kan efter lovens § 54 straffes med bøde. Finanstilsynet kan i en række tilfælde, herunder ved overtrædelse af informationskravene i § 34, offentliggøre navnet på den virksomhed, der har overtrådt loven, såfremt det skønnes at være af interesse for virksom-

\footnotetext{
${ }^{108}$ Lovbekendtgørelse 613/2005.

${ }^{109}$ Det danske Finanstilsynet, der varetager tilsynet med forsikringsformidlingsloven, afholdt i efteråret 2002 - som følge af debat i pressen om salg af tillægsforsikringer i detailhandlen - et møde herom med relevante interesseorganisationer inden for detailhandlen. På mødet aftaltes, at organisationerne overfor deres medlemmer endnu en gang ville indskærpe vigtigheden af, at bestemmelserne om forsikringsformidleres informationspligt overholdes. Se http://www.ftnet.dk/sw366.asp. Det danske Dansk Handel \& Service, som er en arbejdsgiver- og erhvervsorganisation for danske handels- og servicevirksomheder, har på sin hjemmeside på internettet nærmere information om forsikringsformidlingslovens oplysningskrav.
} 
hedens kunder at kende navnet på virksomheden, jf. § 49 a. Der ses ikke at være offentliggjort praksis vedrørende forsikringsformidlingsloven.

Oplysningspligtens overholdelse er i øvrigt undergivet tilsynsmyndighedernes offentligretlige kontrol, jf. således udtrykkeligt islandsk FAL § 12 , norsk FAL $\S 2-3$ og svensk FAL kap. 2, § 9, hvorefter oplysningspligtens tilsidesættelse kan udløse de fremadrettede sanktioner efter den svenske markedsføringslov, jf. herved dennes § 4, stk. 2.

Den finske FAL bestemmer i $\S 9$, stk. 1, at oplysningspligtens manglende opfyldelse eller meddelelse af mangelfulde eller vildledende oplysninger til forsikringstageren medfører, at „försäkringsavtalet vara i kraft med det innehåll som försäkringstagaren hade skäl att sluta sig till utgående från den information han fått.“

Norsk FAL § 2-2, sidste stykke, og svensk FAL $\S 8$ bestemmer, at manglende fremhævelse af nærmere angivne dækningsbegrænsninger medfører, at de pågældende begrænsninger (som udgangspunkt) ikke anses for en del af aftalen.

Også uden en lovbestemmelse som de nævnte finske, norske og svenske kan manglende overholdelse af oplysningsforpligtelserne i alle de nordiske lande efter omstændighederne have civilretlige konsekvenser, mest nærliggende i form af, at der, afhængig af de nærmere omstændigheder, vil være en tendens til at skærpe de aftaleretlige krav, der stilles for at uventede vilkår kan anses for en del af parternes aftale. Desuden vil der være en tendens til i højere grad end ellers at fortolke aftalen til gunst til forbrugeren. Desuden kan oplysningspligtens tilsidesættelse efter omstændighederne medføre, at forbrugeren kan gøre erstatningskrav gældende. Se nærmere under 4.3.

\subsection{Fejl og mangler i forbrugerens beslutningsgrundlag}

Som udgangspunkt er det forbrugerens egen risiko, hvis det viser sig, at han/hun har truffet sin beslutning om at tegne en forsikring på et mangelfuldt eller urigtigt grundlag. Det er dog ikke (fuldt ud) forbrugeren, det går ud over, hvis det mangelfulde eller urigtige beslutningsgrundlag beror på, at forsikringsselskabet eller den detailforretning, der håndterer aftaleindgåelsen på forsikringsselskabets vegne, har givet vildledende oplysninger eller har forsømt at give sådanne oplysninger, som selskabet med videre var nærmest til at give i aftalesituationen, for eksempel fordi dette er foreskrevet i lovgivningen eller i øvrigt ud fra en konkret vurdering var nærliggende ud fra et synspunkt om loyalitet over for forbrugeren som kontraktpart.

Forsikringsselskabet og dets fuldmægtige (dvs. detailforretningerne) har således også en civilretlig oplysningspligt, idet det følger af almindelige kontraktretlige principper om vildfarelse og loyal oplysningspligt, at det efter omstændighederne påvirker forbrugerens kontraktretlige bun- 
dethed og/eller fortolkningen af tillægsforsikringsbetingelserne, hvis forbrugeren svævede i en vildfarelse, jf. herved almindelige ulovbestemte principper om løfters fortolkning og om ugyldighed på grund af en vildfarelse, som enten var fremkaldt af den erhvervsdrivende aftalepart (eller dennes fuldmægtig) eller dog var kendelig for denne (eller dennes fuldmægtig) på aftaletidspunktet, samt den civilretlige generalklausul om tilsidesættelse af urimelige aftalevilkår.

Hertil kommer, at tilsidesættelse af såvel den offentligretlige som den civilretlige oplysningspligt typisk udgør en culpøs handling, som alt andet lige kan begrunde erstatningsansvar for selskabet, der også hæfter for culpa udvist af en detailforretning, der har tilsidesat oplysningspligten i forbindelse med tegning af en tillægsforsikring.

Jf. således det danske Forsikringsankenæunets sag 50.739. Nævnet udtalte:

\begin{abstract}
„Nævnet må lægge til grund, at klageren som angivet har anmodet om en tyveriforsikring for sin computer. Nævnet finder endvidere at måtte lægge til grund, at klageren ikke blev oplyst om, at forsikringen - der også omfatter tyveriskade først trådte i kraft et år efter købsdatoen. Det er nævnets opfattelse, at en sådan oplysning burde være givet en kunde, der efterspørger en tyveridækning. At oplysningen ikke er givet, må efter nævnets opfattelse karakteriseres som en fejl. Det indklagede selskab, der har valgt at sælge forsikring gennem [detailforretningen], findes at måtte hæfte for den begåede fejl, og selskabet skal herefter erstatte klageren den stjålne computer.“
\end{abstract}

I det danske Forsikringsankencevnets sag 39.937 var der modstridende oplysninger om, hvorvidt forbrugeren havde modtaget mundtlig oplysning om, at den købte computer ikke var omfattet af forsikringen i de første 12 måneder (den daværende absolutte reklamationsfrist i den danske KBL). Uanset at forsikringsbetingelserne fandtes meget uheldigt formuleret, fremgik det dog heraf, at forsikringen ikke var trådt i kraft, da tyveriet fandt sted, hvorfor den ikke var dækningsberettiget. ${ }^{110}$

Selv om de fleste af de under 4.2 omtalte oplysningsforpligtelser i hovedsagen af offentligretlig karakter, er det således klart, at deres tilsidesættelse efter omstændighederne kan tillægges en vis civilretlig betydning - også ud over den betydning, der følger af specifikke lovbestemmelser, jf. under 4.2 i.f. om oplysningspligtens civilretlige sanktionering i finsk, norsk og svensk FAL.

Oplysningskravene er jo udslag af, at det legislativt er lagt til grund, at forbrugerne i almindelighed har behov for det påbudte minimum af oplysninger, hvis de i almindelighed skal have mulighed for at træffe beslutning på informeret grundlag. Dette må alt andet lige indebære, at de pågældende oplysninger normalt også civilretligt må anses for egnede til

\footnotetext{
${ }^{110}$ Se også under 3.2.1 om problemstillingen i de to omtalte sager.
} 
at påvirke forbrugerens beslutning og således kan tillægges betydning ved anvendelsen af civilretlige regler om vildfarelser med videre.

Dette synes klart at gøre sig gældende, i det omfang oplysningspligten angår indholdet af tillægsforsikringsdækningen, herunder for eksempel væsentlige dækningsundtagelser og andre begrænsninger i dækningen for eksempel i form af selvrisiko med videre. Manglende eller urigtige oplysning herom er uden videre egnet til at blive tillagt civilretlig betydning. Eftersom de pågældende undtagelser og begrænsninger kun kan påberåbes af selskabet, hvis de er en del aftalen, dvs. fremgår med tilstrækkelig klarhed af forsikringsvilkårene, er manglende oplysning herom da også normalt ensbetydende med, at oplysningspligten så at sige sanktionerer sig selv civilretligt, hvis spørgsmålet giver anledning til tvist mellem parterne.

Jf. for eksempel det norske Forsikringsklagenemndas sag 3341, hvor forsikringsselskabet ikke kunne dokumentere, at der i overensstemmelse med norsk FAL $\S 2.2$, litra c, var udleveret forsikringsbevis til forbrugeren, og dermed heller ikke, at dette indeholdt nærmere angivne sikkerhedsforskrifter, som var påberåbt af selskabet til støtte for ikke at dække en skade. Da det ikke var godtgjort, at forbrugeren af anden vej kendte sikkerhedsforskriften, kunne selskabet ikke påberåbe sig denne, hvorfor forbrugeren fik medhold.

For de omtalte oplysningers vedkommende får spørgsmålet om den civilretlige sanktionering af oplysningspligten derimod selvstændig betydning i de tilfælde, hvor oplysningerne gives prækontraktuelt, men senere viser sig ikke at harmonere med forsikringsbetingelsernes indhold, idet forsikringerne stiller forbrugeren dårligere end oplyst prækontraktuelt.

Mens forbrugeren i almindelighed er vanskeligt stillet i bevismæssig henseende, når forbrugeren gør gældende, at den erhvervsdrivendes mundtlige prækontraktuelle oplysninger ikke stemte overens med den skriftlige kontrakts indhold, stiller det sig anderledes, i det omfang de prækontraktuelle oplysninger om kontraktens indhold er givet skriftligt, således som det er foreskrevet med hensyn til den under 4.2 nævnte oplysningspligt.

Jf. til illustration det danske Forsikringsankencevnets sag 62.786, hvor brochurematerialet i modsætning til tillægsforsikringsbetingelserne ikke indeholdt oplysning om, at tyveridækningen kun omfattede tyveri af en bærbar pc, hvis der forelå indbrudstyveri. Med henvisning til spørgsmålet centrale betydning for forbrugeren, der havde tegnet tillægsforsikring $\mathrm{i}$ forbindelse med køb af bærbar pc, fandtes forsikringen på dette punkt at skulle fortolkes i overensstemmelse med brochurens angivelse af dækningsomfanget. ${ }^{111}$ Jf. også den ovenfor omtalte sag 50.739 fra samme nævn.

\footnotetext{
${ }^{111}$ Afgørelsen er også omtalt ovenfor under 3.1.3.
} 
Heroverfor kan henvises for eksempel til det danske Forsikringsankencevnets sag 62.548, hvor det ikke fandtes godtgjort, at ekspedienten i detailforretningen havde fortalt forbrugeren, at der ikke blev beregnet selvrisiko på 3.000 kr. ved tyveridækning af bærbar pc, hvilket imidlertid fulgte af tillægsforsikringsbetingelserne. Jf. i samme retning den ovenfor omtalte sag 39.937 fra samme nævn

Man må imidlertid også være opmærksom på, at en del af de under 4.2 omtalte oplysningsforpligtelser angår temmelig generelle forhold, såsom købelovgivningens generelle regler om mangler, den almindelige risiko for dobbeltforsikring og så videre., dvs. tillægsforsikringens generelle betydning ved siden af øvrige dækningsmuligheder, i modsætning til for eksempel en præcisering af tillægsforsikringens betydning for den konkrete forbruger, herunder en sammenligning med dennes indboforsikringsdækning med videre. I det omfang oplysningspligten angår sådanne generelle forhold, har den snarere karakter af en advarsel, hvis funktion ikke i første række er at give forbrugeren præcise oplysninger, men snarere at henlede forbrugerens opmærksomhed på, at forbrugeren bør undersøge forholdene (for eksempel sin eksisterende indboforsikringsdækning) nærmere.

Oplysningspligten angår i disse tilfælde forhold, som ofte er for generelle til, at oplysningspligtens manglende opfyldelse i sig selv kan tillægges veldefinerede civilretlige virkninger. Manglende generel oplysning om, at forbrugeren ud over tillægsforsikringen kan påberåbe sig købelovens generelle regler, kan således næppe i sig selv ${ }^{112}$ begrunde civilretlige retsvirkninger til fordel for forbrugeren. Gives der derimod urigtige eller vildledende oplysninger til forbrugeren om dennes retsstilling efter købeloven, synes oplysninger om generelle forhold, alt andet lige, at kunne begrunde civilretlige retsvirkninger til fordel for forbrugeren i samme omfang som urigtige og vildledende oplysninger om konkrete forhold, jf. almindelige aftaleretlige principper om fremkaldt vildfarelse med videre.

Noget andet er, at forholdene i det enkelte tilfælde kan tænkes at være sådan, at de urigtige eller vildledende oplysninger om for eksempel købelovens regler om mangler ikke kan antages at have haft konkret betydning for den enkelte forbruger, for eksempel fordi denne ad anden vej var bekendt med sine rettigheder efter købeloven. I så fald kan de urigtige eller vildledende oplysninger ikke tillægges civilretlig betydning i forholdet mellem forbrugeren og forsikringsselskabet.

Det kan selvsagt meget vel tænkes, at forhold, som ikke er omfattet af den offentligretlige oplysningspligt, kan have stor betydning for forbrugerens beslutningsgrundlag, og at den erhvervsdrivende part i kraft sin særlige viden har haft særlig anledning til loyalt at oplyse forbrugeren herom, således at risikoen for sådanne fejl i beslutningsgrundlaget bør være

${ }^{112}$ Men kan efter omstændighederne sammen med andre forhold tænkes tillagt betydning ved fortolkningen af enkeltvilkår eller ved en rimelighedsvurdering efter den civilretlige generalklausul. 
forsikringsselskabets. Jf. således for eksempel de ovenfor omtalte sager 50.739 og 62.786 fra det danske Forsikringsankenœvnet.

Samme forhold kan efter almindelige kontraktretlige principper om vildledning og loyal oplysningspligt også begrunde, at forbrugeren (i stedet for ugyldighed eller erstatning) kan aktivere reglerne om misligholdelse (kontraktsbrud) og gøre de heraf følgende beføjelser gældende, herunder ophævelsesbeføjelsen gældende.

Jf. det danske Forbrugerklagenæevnets sag 1997-4031/7-512 ${ }^{113}$ om en „totalforsikring“ til $1.595 \mathrm{kr}$. tegnet efter sælgerens anbefaling samtidig med køb af computer med tilbehør og forsikring for i alt 19.394 kr. Forbrugeren blev efterfølgende opmærksom på, at computeren var omfattet af en 3-årig producentgaranti. Forbrugerklagenævnet udtalte, at det måtte påhvile sælger at gøre sig bekendt med eventuelle producentgarantier og at vejlede køberne herom. Dette gjaldt særlig, hvis sælger i forbindelse med købet tilbød en udvidet garanti/forsikring mod betaling. Sælgeren fandtes ved at undlade at oplyse køberen om producentgarantien at have undladt at give køber oplysninger af væsentlig betydning for dennes vurdering af den tegnede totalforsikring, hvorfor køber var berettiget til at hæve den del af købet, som vedrørte forsikringen.

Jf. også det danske Forbrugerklagencevnets sag 1997-4031/7-597, ${ }^{114}$ hvor forbrugeren havde købt en computer med en 3-årig garanti, som indebar, at forbrugeren kunne indsende den defekte computer til en servicepartner, som herefter ville reparere computeren uden beregning. Hvis computeren ikke kunne repareres, var forbrugeren i 3 års perioden berettiget til ombytning af computeren. Det nærmere indhold af denne garanti blev først klarlagt under klagenævnsbehandlingen. Samtidig med købet af computeren tegnede klageren en 4-årig ,totalforsikring“ til 1.495 kr.

Efter ca. $2 \frac{1}{2} 2$ år gik computeren i stykker, og den blev indleveret til sælgeren. Da det ikke var muligt at reparere computeren betalte sælgeren erstatning i henhold til forsikringsbetingelserne svarende til $80 \%$ af nyværdien til køb af ny computer. Forbrugeren, som herefter købte en ny computer hos sælgeren for erstatningssummen plus $600 \mathrm{kr}$., krævede, at sælgeren skulle betale en erstatning svarende til $100 \%$ af computerens købspris, ligesom forbrugeren ønskede forsikringspræmien på $1.495 \mathrm{kr}$. tilbagebetalt. Forbrugeren gjorde gældende, at hun ikke ville have tegnet forsikringen, hvis hun på købstidspunktet havde haft nærmere kendskab til garantien.

Forbrugerklagenævnet fandt, at sælgeren ved at behandle forbrugerens reklamation som en forsikringssag havde afskåret forbrugeren fra at få repareret eller ombyttet computeren uden ekstra omkostninger. Forbrugeren havde derfor krav på tilbagebetaling af den ekstra omkostning på 600 $\mathrm{kr}$. i forbindelse med køb af ny computer. Nævnet udtalte endvidere, at forbrugeren ikke havde haft et reelt behov for den forsikring, som sælge-

\footnotetext{
${ }^{113}$ Jf. Forbrugerstyrelsens Juridisk Årbog 1998 s. 122.

${ }^{114}$ Jf. Forbrugerstyrelsens Juridisk Årbog 1998 s. 123.
} 
ren havde solgt forbrugeren ved købet, idet fejlen ved computeren opstod inden for de 3 første år.

Der påhvilede efter nævnets opfattelse sælgeren en forpligtelse til at undersøge og informere forbrugeren, når der var tale om salg af en vare med garanti. Hvis sælgeren mente, at forsikringen stillede forbrugeren bedre, burde sælgeren på købstidspunktet have fremhævet, på hvilke punkter dette var tilfældet, så forbrugeren havde mulighed for at vurdere, om denne ønskede at tegne forsikringen eller ville nøjes med garantien. Sælgeren havde således ikke ved købet vejledt og informeret forbrugeren forsvarligt. Nævnet fandt forbrugerens forklaring om, at denne ikke havde tegnet forsikringen, hvis denne forud for købet var blevet vejledt og informeret behørigt, for sandsynlig. På denne baggrund var forbrugeren berettiget til at ophæve forsikringsaftalen og kræve forsikringspræmien tilbagebetalt.

\subsection{Fortrydelsesret}

Direktiv 2002/65/EF om fjernsalg af finansielle tjenesteydelser til forbrugerne er implementeret $\mathrm{i}$ alle de nordiske lande. ${ }^{115}$ Direktivet, der som udgangspunkt dikterer totalharmonisering, giver forbrugeren 14 dages fortrydelsesret ved fjernsalg af bl.a. forsikringer, ligesom forsikringsselskabet efter direktivet skal give forbrugeren en række oplysninger ved fjernsalg, herunder om forsikringsselskabet selv, fortrydelsesretten, pris, betaling eventuel klageadgang med videre.

Ved fjernsalg forstås efter direktivets artikel 2, litra a, „enhver aftale om finansielle tjenesteydelser mellem en leverandør og en forbruger, der er indgået under anvendelse af et system til fjernsalg eller fjernlevering af tjenesteydelser drevet af leverandøren, som for den pågældende aftales vedkommende udelukkende anvender en eller flere former for fjernkommunikationsteknik frem til og i forbindelse med selve indgåelsen af aftalen“.

Såfremt tillægsforsikringsaftalen indgås via fjernkommunikationsteknikker, for eksempel telefonisk eller via Internettet, finder fjernsalgsreglerne naturligvis anvendelse også på aftaler om tillægsforsikringer.

Idet de tillægsforsikringer i forbindelse med varekøb, som står i centrum i den foreliggende sammenhæng, ${ }^{116}$ typisk indgås under forbrugerens fysiske tilstedeværelse i selve detailforretningen, er der ikke tale om anvendelse af fjernkommunikationsteknik, hvorfor reglerne i direktivet om fjernsalg af finansielle tjenesteydelser formentlig kun sjældent kan

\footnotetext{
${ }^{115}$ Danmark: lov nr. 451/2004 om forbrugeraftaler; Finland: lag nr. 38/1978 med senere ændringer - konsumentskyddlag; Island: lov 46/2000 Norge: lov 105/2000 med senere ændringer - angrerettloven; Sverige: lag 2005:59 - distans- og hemförsäljningslag..

${ }^{116}$ Se nærmere kapitel 1.
} 
finde anvendelse ved salg af tillægsforsikringer. Fjernsalgsreglerne behandles derfor ikke nærmere i den foreliggende sammenhæng. ${ }^{117}$

Efter dansk ret er forbrugerens fortrydelsesret ved tegning af forsikringer imidlertid ikke begrænset til fjernsalg med videre, men gælder ved enhver salgsform, herunder forsikringstegning, der sker ved tegning af tillægsforsikring i forbindelse med varekøb, jf. dansk FAL § 34 i. $^{118}$

Fortrydelsesfristen er i disse tilfælde 14 dage regnet den dag, forbrugeren modtog underretning om aftalens indgåelse, eller fra den dag, forbrugeren fik tydelig skriftlig oplysning om fortrydelsesretten (hvis denne er senere). Kravene til oplysningspligten er nærmere beskrevet i bekendtgørelse 973/2004, hvoraf fremgår, at oplysningerne kan gives på papir eller andet varigt medium, i form af en særskilt formular eller som en del af forsikringsbetingelserne eller lignende. Hvis oplysningerne er en del af et andet dokument, skal de være „tydeligt fremhævet ved for eksempel særlig skrifttype eller på lignende måde“, jf. bekendtgørelsens § 1, stk. 3.

Oplysningerne skal gives ved anvendelse af en tekst, som fremgår af bilag 2 til bekendtgørelsen, eller en tekst, som giver forbrugeren tilsvarende informationer på en mindst lige så tydelig og forståelig måde, idet selskabet dog kan udelade tekst, der ikke er relevant for den konkrete aftale. Det følger heraf, at der skal oplyses om fortrydelsesfristen og dens beregning, herunder eksemplifikation af beregningen.

Oplysningspligten er som nævnt civilretligt sanktioneret derved, at fortrydelsesfristen ikke begynder at løbe, før oplysningspligten er opfyldt. $^{119}$

\subsection{Forbrugerens dobbeltrolle som køber og forsikringstager}

I mange situationer kan forbrugeren påberåbe sig både købelovens almindelige reklamationsregel/en eventuel garanti og en tegnet tillægsforsikring. Er der således tale om en funktionsfejl, der konstateres inden udløbet af den absolutte reklamationsfrist, og er der samtidig tegnet en tillægsforsikring med en løbetid, der dækker funktionsfejl i en periode, som

\footnotetext{
${ }^{117}$ Blot bemærkes, at forbrugerens kontraktpart ved fjernsalg af tillægsforsikringer i forbindelse med fjernsalg af varer, er leverandøren af den finansielle tjenesteydelse, dvs. forsikringsselskabet, og at oplysningsforpligtelserne ved fjernsalg påhviler denne. Selskabet er ikke afskåret fra at overlade det til formidleren at sørge for, at forbrugeren får oplysningerne, men de civilretlige konsekvenser af oplysningspligtens manglende opfyldelse i form af længerevarende fortrydelsesret kommer selvsagt til at gå ud over leverandøren, i og med at det er denne, der er forbrugerens kontraktpart.

${ }^{118}$ Bestemmelsens stk. 2 undtager fra fortrydelsesretten alene rejseforsikringer mv. med løbetid på højst 1 måned og forsikringsydelser, hvis pris afhænger af udsving på kapitalmarkedet, som selskabet ikke har nogen indflydelse på.

${ }^{119}$ Under tilstanden før oktober 2004 var oplysningspligten sanktioneret med ugyldighedsvirkning. Jf. herved det danske Forsikringsankenæevnets sag 58.843, hvor oplysningen om fortrydelsesret fandtes mellem forsikringsbetingelserne og ikke levede op til kravet om tydelig fremhævelse ved særlig skrifttype eller lignende måde, hvorfor aftalen ikke var bindende forbrugeren. Selskabet havde derfor ikke krav på nogen præmie eller anden ydelse.
} 
(delvis) overlapper den køberetlige reklamationsperiode, ${ }^{120}$ kan forbrugeren efter samtlige nordiske landes regler under alle omstændigheder påberåbe sig såvel tillægsforsikringen som de køberetlige regler, der er præceptive i forbrugerforhold. Oplysninger i pressen og fra deltagerne i projektgruppen tyder da også på, at visse detailforretninger i sådanne situationer i et vist omfang henviser forbrugeren til at benytte sig af tillægsforsikringen.

Problemet herved er ikke kun, at detailleddet på denne måde overvælter omkostninger på forsikringsselskabet, der burde bæres af detailleddet selv eller producenten. Problemet forøges af, at mange tillægsforsikringer indeholder vilkår om selvrisiko, jf. kapitel 2 ovenfor. I så fald kan forbrugeren komme i den absurde situation, at en ellers gratis ret til afhjælpning eller omlevering efter de køberetlige regler pludselig er erstattet med en forsikringsdækning, som forbrugeren ikke blot har købt og betalt for, men også skal betale en ofte ikke helt ubetydelig selvrisiko for at udnytte.

Det danske Forbrugerklagencevnets sag 2004-4031/7-749 vedrørte netop en sådan situation. En forbruger købte en bærbar computer til knap $22.000 \mathrm{kr}$. og tegnede samtidig en tillægsforsikring (i den konkrete sag benævnt „tryghedsforsikring“). Ca. 1 år og 4 måneder senere konstaterede forbrugeren en fejl ved computeren og reklamerede derfor over for den erhvervsdrivende. Denne anerkendte manglen, men afviste kravet med henvisning til, at fejlen ikke gav forbrugeren beføjelser i henhold til købeloven, men alene i henhold til den tegnede forsikring. Dækning under forsikringen ville indebære, at forbrugeren skulle betale en selvrisiko på $550 \mathrm{kr}$.

Forbrugerklagenævnet udtalte bl.a., at

\begin{abstract}
„, de tilfælde hvor købelovens beskyttelsespræceptive regler om mangler i forbrugerkøb finder anvendelse, så kan den omstændighed, at køberen har tegnet en tillægsforsikring, ikke føre til, at køberen ved en reklamation stilles ringere, end hvad der følger efter købeloven. F.eks. kan sælgeren ikke opkræve selvrisiko under henvisning til forsikringsbestemmelserne, hvis køberens reklamation vedrører en mangel, der (også) efter købelovens regler berettiger køberen til at få varen ombyttet“.
\end{abstract}

Nævnet tilføjede, at såfremt den erhvervsdrivende ville gøre gældende, at en fejl, der afhjælpes i form af vederlagsfri ombytning inden for købelovens reklamationsfrist, ikke er en mangel i købelovens forstand, men en fejl, der alene dækkes af forsikringen, bærer den erhvervsdrivende bevisbyrden herfor. Den erhvervsdrivende havde i den konkrete sag ikke løftet denne bevisbyrde, og idet computeren var bortskaffet af den erhvervsdrivendes værksted, forinden nævnets sagkyndige kunne foretage en vurdering af manglen, måtte det komme den erhvervsdrivende bevismæssigt til

\footnotetext{
${ }^{120}$ Den i teksten nævnte forudsætning er ikke altid til stede, idet visse tillægsforsikringer, jf. bilag 2, efter deres indhold ikke dækker, i det omfang forholdet dækkes efter køberetlige regler om mangler.
} 
skade, at det ikke i sagen var muligt at fastslå, hvilken fejl computeren havde. Nævnet pålagde følgelig den erhvervsdrivende at tilbagebetale det opkrævede selvrisikobeløb (inkl. rente).

Afgørelsen fastslår for det første det i og for sig juridisk selvfølgelige, at forbrugeren ikke ved tegning af en tillægsforsikring kan afskæres fra at påberåbe sig købelovens beskyttelsespræceptive regler, når der foreligger en mangel.. Er forbrugeren ikke bekendt med de køberetlige regler og henviser forretningen med urette forbrugeren til at søge dækning under forsikringen, kan den faktiske virkelighed imidlertid ofte være, at forbrugeren, hvor denne har tegnet en tillægsforsikring, de facto risikerer at blive henvist til at udnytte denne og derved kommer til at betale for udnyttelse af en præceptiv - og gratis - ret i henhold til lovgivningen.

Afgørelsen viser for det andet, at relevant faktuel tvivl med hensyn til spørgsmålet om, hvorvidt den begivenhed, der udløste en reparation eller omlevering/genlevering, (også) kunne gøres gældende som en køberetlig mangel, i almindelighed går ud over sælgeren, idet denne i situationen er nærmest til at sikre sig i bevismæssig henseende inden reparation eller kassation af den oprindelige salgsgenstand.

Spørgsmålet om, hvorvidt tegning af en tillægsforsikring af detailforretningen benyttes til at afvise i øvrigt gyldige reklamationskrav efter de køberetlige regler, førte i 2003 til, at den finske Konsumentombudsmannen bad en af de største formidlere af tillægsforsikringer, ONOFF, om en redegørelse. Ifølge redegørelsen har ONOFF og deres forsikringsselskab, SOLID, udformet skriftlige retningslinier og forretningsprocedurer, der skal modvirke, at problemet opstår.

\subsection{Tillægsforsikringers førtidige ophør}

Som tidligere berørt ${ }^{121}$ er dækningen efter de fleste tillægsforsikringer begrænset til at angå en nærmere bestemt angivet salgsgenstand. ${ }^{122}$ Dette har den følge, at tillægsforsikringsdækningen ikke længere er relevant, når den pågældende genstand kasseres, for eksempel fordi der sker omlevering efter køberetlige regler om mangler, eller fordi der indtræder totalskade. På tilsvarende måde antages forsikringen i almindelighed at ophøre, hvis den forsikrede interesse i øvrigt bortfalder, f.eks. fordi den forsikrede ting skifter ejer. ${ }^{123}$

Om forsikringstagerens ret til førtidig opsigelse af en skadesforsikring, herunder tillægsforsikring, finder der præceptive regler i finsk FAL $\S 12$, norsk FAL § 3-6 og svensk FAL kap 3 §, som alle giver forsikringstageren en generel eller dog temmelig vidtgående opsigelsesadgang.

\footnotetext{
${ }^{121}$ Se under 3.2.1.

${ }^{122}$ Se dog fx bilag 2.1, bilag 2.7 og bilag 2.13, som modificerer dette en smule ved fastsætte, at tillægsforsikringen også omfatter det nye apparat, hvis der sker genlevering, når dette ikke skyldes totalskade.

${ }^{123}$ Se i øvrigt nærmere under 4.7.2 om ejerskifte.
} 
Dansk FAL indeholder ikke tilsvarende regler, og det må på den baggrund antages, at forbrugeren, i mangel af særlige holdepunkter i aftalen, ikke har nogen almindelig opsigelsesadgang ved tillægsforsikringer, der er indgået for en bestemt periode. ${ }^{124}$

Idet tillægsforsikringerne typisk er indgået for en bestemt, længere periode, normalt 3 eller 5 år, og hele forsikringspræmien typisk betales ved tegningen, opstår i de nævnte tilfælde - og andre tilfælde af tillægsforsikringens førtidige ophør - spørgsmål om, hvorvidt forbrugeren har krav på tilbagebetaling (såkaldt ristorno) af en del af den betalte præmie ud fra det synspunkt, at forbrugeren ikke kommer til at nyde godt af forsikringsselskabets modydelse, dvs. nærmere angivet risikoovertagelse i en bestemt periode, i det forudsatte omfang.

Tillægsforsikringerne indeholder undertiden vilkår om, at der ikke skal ske tilbagebetaling ved totalskade, men indeholder i øvrigt normalt ikke bestemmelser om spørgsmålet. ${ }^{125}$

Det forsikringsretlige udgangspunkt synes at være, at der i tilfælde af forsikringens førtidige ophør skal ske en regulering af præmieforholdene, således at parterne stilles, som om forsikringen var tegnet for den kortere periode, som faktisk blev resultatet, og således at der i givet fald skal ske tilbagebetaling af for meget betalt præmie, jf. de præceptive bestemmelser i dansk FAL $\S 16$, stk. 2, finsk FAL $\S 45$, islandsk FAL $\S 14$, jf. § 17, norsk FAL $\S 3-9$ og svensk FAL kap. 5 § 6 .

Dette er statueret af det danske Forsikringsankenæevnet $i$ sagerne 44.024 og 50.647, som begge angik tilfælde, hvor forsikringen bortfaldt på grund af tyveri af den forsikrede genstand inden for det først år efter købet, hvor forsikringen endnu ikke var trådt i kraft. I sag 50.647 udtalte Forsikringsankencevnet bl.a.:

„Da klageren har mistet udstyret, endnu før forsikringen er trådt ikraft, og da selskabet således på intet tidspunkt har været i risiko, finder nævnet, at klageren er berettiget til at få tilbagebetalt præmien på 1.545 kr. “

Er forsikringsdækningen ophørt på grund af en totalskade, som er omfattet af forsikringsdækningen, synes det derimod at være det almindelige forsikringsretlige udgangspunkt, at der ikke sker tilbagebetaling, idet forsikringsdækningen i disse tilfælde siges at være udtømt eller forbrugt. $^{126}$

\footnotetext{
${ }^{124}$ Derimod er det i den danske lov om finansiel virksomhed § 57 bestemt, at et forsikringsselskab, der udbyder forbrugerforsikringer, skal tilbyde, at de pågældende forsikringer kan tegnes på vilkår om, at forsikringen kan opsiges af forsikringstageren med et varsel på 30 dage til udgangen af en kalendermåned. Bestemmelsen gælder ikke ved bl.a. livsforsikring eller korttidsforsikringer. Tillægsforsikringerne er ikke undtaget. Bestemmelsen trådte i kraft i oktober 2004.

${ }^{125}$ Se fx bilag 2.1, og bilag 2.6. Bilag 2.3 og bilag 2.7 indeholder regler om, at der i tilfælde af forbrugerens opsigelse af forsikringen beregnes korttidspræmie.

${ }^{126}$ Jf. Ivan Sørensen: Forsikringsret (4. udg., 2005) s. 109.
} 
Dette er kommet klart til udtryk i det danske Forsikringsankencevnets sag 40.061 (som ikke angår tillægsforsikringer, men forsikring af en motorcykel). I denne sag udtalte nævnet:

\footnotetext{
„I den forsikringsretlige litteratur er det antaget, at selskabet i almindelighed ikke skal ristornere præmie i tilfælde, hvor den forsikrede interesse er gået til grunde ved en forsikringsbegivenhed. Imidlertid er der på området for motorkøretøjsforsikring en fast praksis for, at præmie ristorneres, selv om interesseophøret skyldes forhold, for hvilke selskabet er forpligtet at yde erstatning.

Selv om nærværende forsikring er tegnet som en all-risk-forsikring, finder nævnet, at forsikringens indhold er at sammenligne med en kaskoforsikring for motorkøretøjer, og nævnet finder derfor, at klageren har krav på at få ristorneret den del af præmien, der vedrører den forsikringsperiode, hvor selskabet ikke har været i risiko.“
}

Selv om der således anerkendes undtagelser fra det anførte udgangspunkt om, at der ikke skal ske tilbagebetaling af restpræmien ved en forsikringsdækket totalskade, der bringer forsikringen til ophør, synes hidtidig dansk praksis ikke være lydhør for at udstrække undtagelserne til tillægsforsikringer.

Jf. det danske Forsikringsankencevnets sag 47.410, hvor en „totalforsikring“ for et tv-apparat var i kraft i mindre end to måneder, før der indtrådte en totalskade. Forbrugeren klagede over, at forsikringsselskabet ikke ville overføre forsikringen til et nyt apparat og heller ikke ville refundere en del af præmien. Nævnet, der ikke gav klageren medhold, udtalte:

\footnotetext{
„Nævnet må lægge til grund, at klagerens tv-apparat er ophugget som følge af totalskade. Selv om der resterer mere end 4 år af forsikringsperioden, finder nævnet ikke grundlag for at tilsidesætte bestemmelsen om, at forsikringen bortfalder ved totalskade. Nævnet bemærker, at nævnet ikke kan kritisere, at selskabet som sket har begrænset sit ansvar til maksimalt at udbetale det forsikredes værdi een gang i forsikringsperioden.“
}

\subsection{Vildledende/urimelige vilkår i tillægsforsikringer}

Ud fra et forbrugerbeskyttelsessynspunkt kan der sættes spørgsmålstegn ved rimeligheden af visse af vilkår i de tillægsforsikringer, som er udbredte i praksis. Der sigtes hermed til de rimelighedskriterier, der ligger til grund for den forbrugerbeskyttende aftalevilkårsregulering, som i alle de nordiske lande muliggør fremadrettede indgreb mod anvendelsen af urimelige aftalevilkår i erhvervsdrivendes kontrakter. Jf. direktiv 93/13/EF om urimelige kontraktvilkår i forbrugeraftaler art. 7, hvorefter medlemsstaterne skal sikre, at der findes egnede og effektive midler til at bringe anvendelsen af urimelige kontraktvilkår i aftaler, der indgås mellem forbrugerne og de erhvervsdrivende, til ophør. Direktivet, der er et minimumsdirektiv, jf. dets artikel 8, er implementeret i alle de nordiske 
lande, som allerede inden direktivet havde udviklet en praksis på området. $^{127}$

\subsubsection{Eksempler på vildledende/urimelige vilkår}

Et praktisk vigtigt kriterium, der har fæstnet sig i de nordiske landes forbrugerbeskyttende aftalevilkårsregulering, går ud på, at aftalevilkår, der efter deres ordlyd er i strid med beskyttelsespræceptiv lovgivning eo ipso er urimelige, fordi de er egnet til at vildlede forbrugeren om retsstillingen mellem parterne, og vanskeligt kan siges at tjene noget beskyttelsesværdigt formål.

Ud fra et tilsvarende synspunkt kan der skrides ind over for aftalevilkår, som efter deres ordlyd nærliggende må forstås således, at de hjemler resultater, som er i strid med beskyttelsespræceptive regler.

Set i lyset af de anførte kriterier synes der at kunne sættes spørgsmålstegn ved rimeligheden af visse af de almindeligt forekommende vilkår i tillægsforsikringer.

Et tilsyneladende hyppigt anvendt aftalevilkår i tillægsforsikringer definerer forsikringsbegivenheden ved hjælp af bl.a. termen „hændeligt uheld“, hvorved sigtes til pludselige, udefra kommende begivenheder. ${ }^{128}$

Ordet „hændeligt“ forstås i såvel juridisk som daglig sprogbrug synonymt med „ikke uagtsomt og ikke forsætligt“, dvs. „kan ikke gøre for“, „ikke min skyld“ etc. Eftersom det følger af forsikringsaftalelovgivningens beskyttelsespræceptive regler, at selskabet ikke kan undtage forbrugerens fremkaldelse af forsikringsbegivenheden ved simpel uagtsomhed fra dækningsområdet, ${ }^{129}$ kan det være nærliggende at anse vilkår som de nævnte for egnet til at vildlede forbrugeren om retsstillingen.

Et andet hyppigt anvendt vilkår går ud på at gøre undtagelse fra forsikringsdækningen, hvis forsikringsbegivenheden skyldes „uforsvarlig anvendelse og betjening af apparatet“ “ ${ }^{130}$ Også i disse tilfælde er der tale om, at formuleringen går videre, end der er belæg for efter beskyttelsespræceptive regler, hvorfor vilkåret synes at være egnet til at vildlede forbrugeren om retsstillingen.

Jf. herved det danske Forsikringsankenæevnets sag 47.574, hvor nævnet bl.a. udtalte:

„Nævnet bemærker herved, at brug af undtagelsesbestemmelsen om uforsvarlig anvendelse og betjening af apparatet må forudsætte, at den sikrede har fremkaldt forsikringsbegivenheden ved en uagtsomhed, der kan tilregnes ham som (mindst) groft uagtsom, jf. forsikringsaftalelovens § 20.“

\footnotetext{
${ }^{127}$ Se nærmere Børge Dahl og Peter Møgelvang-Hansen: Garantier - Forbrugerproblemer og forbrugerbeskyttelse i de nordiske lande (1985) s. $145 \mathrm{ff}$ for en oversigt over de grundlæggende bedømmelseskriterier, der er udviklet i nordisk praksis.

${ }^{128}$ Se nærmere under 3.1.3.

${ }^{129}$ Se nærmere under 3.1.3.

${ }^{130}$ Formuleringen er for generel til, at vilkåret kan anses for en ”sikkerhedsforskrift”, se nærmere herom under 3.1.3.
} 
Vildledende virker også dækningsundtagelser, der er så vidtgående, at forsikringsdækningen i realiteten, hvis dækningsundtagelserne opretholdes i overensstemmelse med deres ordlyd, må anses for værdiløs for forbrugeren.

Jf. herved danske Forbrugerklagencevnets sager 1991-4012/7-72 og 1990-133-622, ${ }^{131}$, hvor forbrugeren ved køb af en videomaskine med fjernbetjening indgik aftale om 4 årig „Udvidet ... Total Sikkerhed“. Ca. to år senere blev videomaskinen totalskadet, da forbrugerens søn kom til at vælte en vase med vand ned i maskinen. Den 4-årige ordning omfattede bl.a. „reparation af hændelige, uforsætlige uheld“, men indeholdt en undtagelse om, at den ikke omfattede fejl og skader, opstået „ved udefra kommende påvirkninger af enhver art, herunder stød, slag, naturkatastrofer“. Sælgeren gjorde gældende, at den foreliggende skade var omfattet af undtagelsen og derfor ikke dækningsberettiget, men fik ikke medhold.

Forbrugerklagenævnet udtalte, at den nævnte undtagelsesbestemmelses rækkevidde var ganske uklar, og at fortolkningstvivlen måtte komme sælgeren til skade. Forbrugerklagenævnet udtalte desuden, at et så vidtgående forbehold, som sælgeren hævdede at have taget, må anses som ugyldigt i forbrugerforhold, jf. den civilretlige generalklausul, da det praktisk taget ville dække alle „hændelige, uforsætlige uheld“ og dermed i realiteten gøre den tegnede serviceordning værdiløs. .

Undertiden indeholder tillægsforsikringsvilkårene en bestemmelse om, at forsikringen kun gælder for køberen, og ikke for en ny ejer. ${ }^{132}$ Set fra et forbrugersynspunkt kan det umiddelbart virke mindre rimeligt, at en forudbetalt, langvarig tillægsforsikring ikke uden videre følger med varen ved dennes overdragelse.

Dette umiddelbare indtryk forstærkes af, at forsikringsselskaberne ved tegning af tillægsforsikringer i forbindelse med varekøb ikke synes at tillægge oplysninger om forsikringstagerens person nogen som helst betydning for præmieforhold eller tegningen i øvrigt, ligesom ejerskiftet vel næppe i sig selv kan siges at forøge risikoen for forsikringssvindel.

Ikke desto mindre synes det at være det almindelig forsikringsretlige udgangspunkt, at den interesse, der er tegnet forsikring for, falder bort, når den ting, interessen er knyttet til, skifter ejer, ${ }^{133}$ og der er på denne baggrund muligvis ikke tilstrækkeligt holdepunkt for at anse vilkår, der svarer hertil, for urimelige.

\footnotetext{
${ }^{131}$ Jf. Forbrugerstyrelsens Juridisk Årbog 1992 s.147

${ }^{132}$ Se fx bilag 2.1 og bilag 2.13, hvorefter forsikringen kun kan overgå til ny ejer efter henvendelse til detailforretningen, og 2.7 (hvorefter forsikringsselskabet skal godkende ny ejer). Bilag 2.5 er tavs om spørgsmålet, mens bilag 2.4 udtrykkeligt angiver, at forsikringen overgår til ny ejer af genstanden.

${ }^{133}$ Jf. således Henning Jønsson \& Lisbeth Kjærgaard: Dansk Forsikringsret (8. udg., 2003).
} 


\subsubsection{Vilkår, der kan give forbrugeren skuffede forventninger}

Visse (typisk udvidede) tillægsforsikringer er affattet således, at de kan give forbrugeren anledning til at tro, at der i for eksempel de to første år slet ikke foretages afskrivning i erstatningssummen. Det sker gennem vilkår som: „der er ingen ned- eller afskrivning på forsikringen i de første to år". Som tidligere omtalt er det en forsikringsretlig grundsætning, jf. for eksempel dansk FAL $\S 39$, at skadelidte ikke kan blive beriget ved erstatningen (,berigelsesforbuddet“).

Medmindre der på andet grundlag, for eksempel via detailforretningens oplysninger til forbrugeren i forretningen, kan siges at være afgivet et løfte om at stille forbrugeren bedre end almindelige forsikringsretlige principper ville føre til, kan de forventninger om erstatningens størrelse, som eventuelt skabes hos forbrugeren gennem formuleringen af tillægsforsikringen, således blive skuffede.

Se om problemstillingen det danske Forsikringsankencevnets sag 63.323. Her klagede en forbruger, der havde købt en udvidet tillægsforsikring (benævnt „luksusforsikring“) til en pc, over den tilbudte erstatning efter at pc'en var totalskadet. Købsprisen var 16.000 kr., og forsikringsselskabet tilbød en erstatning på 10.000 kr. Pc'en var på skadestidspunktet 3 år gammel. Af forsikringsvilkårene fremgik, at „der er ingen nedskrivning på forsikringen“, og „udstyr, der er blevet totalskadet....erstattes med nyt udstyr efter eget valg, dog maksimalt det betalte købsbeløb, som fremgår af policen“.

Forbrugeren hævdede over for nævnet desuden, at sælgeren i forretningen havde oplyst, at tillægsforsikringen indebar, at forbrugeren til enhver tid i dækningsperioden kunne få udbetalt den fulde købesum på $16.000 \mathrm{kr}$. i tilfælde af totalskade. Forsikringsselskabet henviste til FAL $\S \S 37$ og 39, hvorefter erstatningen opgøres efter genanskaffelsesprincippet og under ingen omstændigheder kan føre til en berigelse af den sikrede.

Nævnet fandt, at vilkårene i tillægsforsikringen måtte forstås i overensstemmelse med principperne i FAL og afgjorde derfor sagen til fordel for selskabet. Forbrugerens anbringende om, at ekspedienten ved de urigtige oplysninger om forståelsen af tillægsforsikringen havde afgivet et selvstændigt aftaleretligt løfte om en større dækning end forsikringen gav grundlag for, fandtes ikke bevist ved forbrugerens egen forklaring herom til nævnet.

Det danske Forsikringsankencevnets sag 63.823 er stort set identisk hermed. Forbrugeren havde tegnet en tillægsforsikring (også her i form af en „luksusforsikring“) i forbindelse med køb af en bærbar pc. Købsprisen var 13.000 kr. Da pc'en 2 år efter købet blev totalskadet, tilbød forsikringsselskabet $9.000 \mathrm{kr}$. i erstatning. Forbrugeren påstod at have krav på at få den fulde købspris på 13.000 kr. erstattet, under henvisning til vilkårene i tillægsforsikringen, hvoraf - som i sagen ovenfor - fremgik, at „der er ingen nedskrivning på forsikringen“, og „udstyr, der er blevet totalska- 
det...erstattes med nyt udstyr efter eget valg, dog maksimalt det betalte købsbeløb, som fremgår af policen“. Desuden hævdede forbrugeren, at ekspedienten havde oplyst, at forbrugeren ville få det fulde beløb på 13.000 kr. dækket. Selskabet afviste at dække beløbet på 13.000 kr. med henvisning til FAL $\S \S 37$ og 39.

Nævnet gav selskabet medhold og udtalte bl.a., at „en erstatning, der overstiger de tilbudte 8.999 kr., vil føre til, at klageren får en højere erstatning, end han har lidt i tab. Uanset formuleringen i de ovenfor gengivne forsikringsbetingelser kan nævnet derfor ikke kritisere størrelsen af den tilbudte erstatning.“ ${ }^{134}$

Se fra norsk ret tilsvarende Forsikringsskadenemndas kendelse i sag 4027. En forbruger købte en mobiltelefon med tilhørende tillægsforsikring. Godt et år efter købet blev telefonen stjålet på forbrugerens arbejdsplads. I erstatningssummen fradrog forsikringsselskabet $30 \%$ som følge af, at forbrugeren ikke havde opfyldt sikkerhedsforskrifterne ifølge forsikringsvilkårene. Desuden fradroges 15 \% pga. alder samt en selvrisiko på $300 \mathrm{kr}$.

Forbrugeren hævdede, at han/hun ikke havde modtaget nogen information om forsikringen og krævede „fuld erstatning“, hvilket måtte forstås som den fulde købesum. Idet selskabet ikke kunne godtgøre at have fremsendt forsikringsvilkårene til forbrugeren, fik forbrugeren medhold for så vidt angik fradraget vedrørende den manglende opfyldelse af sikkerhedsforskrifterne. Derimod fik forbrugeren ikke medhold vedrørende selvrisikoen, og heller ikke vedrørende fradraget for alder, der fandtes at være i overensstemmelse med almindelige forsikringsretlige regler.

Som de omtalte sager viser, fortolkes vilkår i tillægsforsikringer - naturligt nok - i overensstemmelse med almindelige forsikringsretlige principper, og der er for så vidt ikke belæg for at anse dem for urimelige. Set i sammenhæng med den måde, hvorpå tillægsforsikringer i forbindelse med varekøb i øvrigt præsenteres for forbrugerne, kan spørgsmålet dog efter omstændighederne stille sig anderledes. Ved en tæt sammenkædning af tillægsforsikringen og køberetlige regler om mangler, idet tillægsforsikringsdækningen for eksempel beskrives som en „forlængelse af de køberetlige rettigheder“ ${ }^{135}$ uden samtidig klargøring af, at tillægsforsikringsydelsen udmåles efter kriterier, som ofte fører til lavere dækning end de køberetlige regler, kan aftalevilkårene således være egnede til at vildlede forbrugerne.

\footnotetext{
${ }^{134}$ Nævnet tilføjede, at det ikke kunne tage stilling til, om forretningen, såfremt den havde givet forbrugeren urigtige oplysninger om forståelsen af forsikringen, herved havde overtrådt reglerne om god skik for forsikringsselskaber, idet afgørelsen heraf henhører under Finanstilsynet. Se om godskik reglerne ovenfor under 4.2 .

Se fx bilag 2.2.
} 



\section{Retspolitiske overvejelser}

\subsection{Tillægsforsikringer som forbrugerretspolitisk problem}

Denne rapport har vist, at tegning af tillægsforsikringer ved varekøb i praksis giver anledning til en række forbrugerproblemer i de nordiske lande. Idet markedet for tillægsforsikringer er ganske stort, i hvert fald i Danmark, Norge og Sverige, og idet prisen for en tillægsforsikring er relativt høj (sammenlignet med prisen for selve hovedproduktet), jævnfør i det hele rapportens kapitel 2, kan disse problemer ud fra en forbrugerretspolitisk betragtning næppe negligeres.

Det altoverskyggende problem synes at være, jævnfør kapitel 3, at tillægsforsikringer ofte giver forbrugeren få reelle fordele, som rækker ud over den beskyttelse, forbrugeren allerede nyder efter købelovgivningen, en eventuel produktgaranti og den indboforsikring, som langt de fleste forbrugere er i besiddelse af.

En standard-tillægsforsikring, der kun dækker egentlige funktionsfejl og eventuelt skader, der er dækket af enhver normal indboforsikring, og som tidsmæssigt ikke eller kun i beskedent omfang rækker ud over den præceptive reklamationsfrist i det pågældende land, tilfører ikke forbrugeren væsentlige fordele sammenlignet med den beskyttelse, forbrugeren har i forvejen.

Omvendt er der naturligvis også tillægsforsikringer på markedet, der må antages at give forbrugeren reelle fordele, idet de går væsentligt længere end købelovgivningen/garantivilkår og en eventuel indboforsikring. Det gælder navnlig udvidede tillægsforsikringer, der i relation til indhold eller længden af dækningsperioden samlet set rækker ud over den beskyttelse, forbrugeren har i forvejen. En tillægsforsikring, der har en varighed på mere end 3 år, og som indholdsmæssigt dækker over mere end blot funktionsfejl og forhold, der typisk dækkes efter enhver normal indboforsikring, kan indebære væsentlige og reelle fordele for forbrugeren. Disse fordele må selvsagt vurderes i lyset af prisen for den pågældende tillægsforsikring.

Det kan hævdes, at det forhold, at mere end 1/3 af alle tillægsforsikringer tilsyneladende udnyttes, i sig selv er et vidnesbyrd om, at der er reelle fordele ved at købe en tillægsforsikring. Tallet skal imidlertid tages med forbehold, idet det næppe kan udelukkes, at den relativt høje udnyttelsesprocent til en vis grad dækker over, at også sådanne fejl ved produktet, der udgør køberetlige mangler, eller at også hændelser, som er omfattet af indboforsikringsdækning, i praksis dækkes under tillægsforsikringen.

Den omstændighed, at tillægsforsikringer ved varekøb juridisk set ligger i grænseområdet mellem købe- og forsikringslovgivning indebærer 
endvidere, at vurderingen af tillægsforsikringens eventuelle fordele kræver en detailviden om forbruger- og forsikringslovgivning, som de færreste forbrugere kan formodes at være i besiddelse af.

Vanskelighederne herved forstærkes af den betydelige uensartethed, der som beskrevet præger de gældende tillægsforsikringer, og som i sig selv kan udgøre et væsentligt forbrugerproblem ved tillægsforsikringer. Uensartetheden medfører, at vurderingen af, hvorvidt den givne tillægsforsikring reelt giver forbrugeren en fordel i den konkrete situation, ofte kan være ret vanskelig, idet vurderingen forudsætter en nærmere undersøgelse af indholdet af den konkrete tillægsforsikring og en sammenligning heraf ikke blot med købelovens regler og en eventuel garanti, men også af tillægsforsikringsdækningen med den indboforsikringsdækning, som langt størstedelen af de nordiske forbrugere nyder godt af. ${ }^{136}$ Forbrugeren skal så at sige navigere rundt $i$ et landskab med mange ubekendte.

Hvis det lykkes forbrugeren at fastslå, i hvilket omfang tillægsforsikringen reelt indebærer fordele for forbrugeren, må den enkelte forbruger ydermere vurdere, om prisen for tillægsforsikringen står i et rimeligt forhold til den opnåede fordel.

De vanskeligheder, den enkelte forbruger kan have med at vurdere fordelen ved at købe en tillægsforsikring, bliver selvsagt ikke mindre af, at beslutningen om tegning af tillægsforsikring i praksis oftest træffes i en for forsikringstegning temmelig atypisk situation.

I praksis er beslutningen om tegning af tillægsforsikringer således ofte kendetegnet ved et vist moment af overrumpling, for så vidt som forbrugeren har indfundet sig i detailforretningen, ikke for at tegne en forsikring, men for at købe den pågældende vare (vaskemaskine, TV, pc, digital kamera, etc.), og at spørgsmålet om tegning af tillægsforsikring oftest må formodes først at komme ind i billedet, efter at forbrugerens beslutning om køb af en bestemt vare er truffet, dvs. på et tidspunkt, da forbrugerens „parader“ vel ofte i en vis forstand kan siges at være „nede“, idet forbrugeren vel nærmest mentalt er på vej ud af forretningen og næppe i samme grad er på vagt over for sælgerens „overtalelsesforsøg“, som i fasen indtil beslutningen om at købe varen. Situationen lægger tillige op til, at beslutningen om eventuelt at tegne en tillægsforsikring skal træffes „på stedet“, i forretningen, i løbet af kort tid, inden forbrugeren forlader forretningen.

Som yderligere momenter, der kendetegner situationen, fremhæves, at beslutningen træffes på baggrund af oplysninger fra en butiksekspedient, der i udgangspunktet ikke er uddannet til at formidle forsikringer, og som ofte modtager provision fra salget af tillægsforsikringer og derfor har en klar egeninteresse i at sælge så mange tillægsforsikringer som muligt.

Til konkret illustration af, hvorledes forholdene kan tage sig ud set fra den enkelte forbrugers synsvinkel, henvises til det nedenfor citerede ud-

\footnotetext{
${ }^{136}$ Se nærmere 3.1.3 om indboforsikringers udbredelse mv.
} 
drag af en henvendelse, som det svenske Konsumentverket modtog i februar 2005: ${ }^{137}$

”Vi har köpt en TV-apparat på [forretningens navn] 2000-03-03 för 4.890 kr. Säljare var mycket angelägen att sälja en extra försäkring som kostade 795 kr. och som enligt honom garanterade TVs reparation under 5 år. Vi fick inte något avtal på papper innan försäkringen var betald, försäljaren nämnde inte heller om vissa försäkringsvillkor som begränsar egentligen dess verkan till en kortare period eller gör den överhuvudtaget värdelös.

Denne TV-apparat gick sönder i december 2004 och vi lämnade den på [forretningens navn] för reparation i början av januari 2005. I slutet av januari fick vi besked från [foretningens navn] att försäkringsbolaget anser att reparationer kostar så pass mycket att det inte lönar sig att reparera TV men erbjuder istället 800 kronor i ersättning och behåller TV. Handläggaren på [forsikringsselskabets navn] bekräftade detta och lade till att bara kalla en reparatör kommer att kosta 900 kr och det var beloppet som vår TV var värd just nu. Han hänvisade till ett villkor i avtalet där det står att värdet på den försäkrade varan avskrivs med 20 \% varje påbörjat år dock högst med $80 \%$.

Vi har svårt att förstå varför bolaget säljar försäkringar för varor vars värde kommer med stor sannolikhet att understiga reparationskostnader redan under fjärde år av förbrukning eftersom då är t.ex. vår TV-apparat värd c:a 1800 kr vilket räcker inte heller för at täcka reparationskostnader. Antagligen, lönar det sig om man försäkrar en dyrare vara men inte i vårt fall och detta borda företaget veta redan i början. Dessutom har man alltid fria reparationer under första 24 månader ${ }^{138}$ vilket gör att man inte behöver besvära försäkringsbolaget. Med andre ord kan denna försäkring vara till nytta bara under tredje året av förbrukning vilket inte stämmer alls med vad som var sagt på [forretningens navn].

Vi ser dessa försäkringsvillkor som ett förfinat bedrägeri där vinnare är alltid försäkringsföretag med inte konsument. [Forretningens navn] i sin tur måste ha vetat att de säljer värdelösa försäkringar som de nästan påtvingar sina kunder.

Visst, har konsument ett ansvar att alltid kolla försäkringsvillkor, men när man bliver övertygad av en försäljare på ett som man tror seriöst företag att alla skador kommer repareras under 5 år framöver litar man på detta. Man kan inte veta heller vad det kommer att kosta att utföra en reparation och jämnföra detta med varans värde för varje förbrukningsår.”

Et afgørende spørgsmål i forbindelse med tegning af tillægsforsikringer ved varekøb synes således at være, om forbrugeren har et betryggende beslutningsgrundlag.

For besvarelsen af dette spørgsmål er det væsentligt, om de gældende regler om tillægsforsikringer i tilstrækkelig grad understøtter forbrugerens mulighed for at træffe en rationel beslutning på et fyldestgørende grundlag. Hvis ikke, kan der være grund til at overveje retspolitiske initiativer, der kan øge forbrugerbeskyttelsen.

Som beskrevet i kapitel 4 er nordiske forbrugere ved køb af en tillægsforsikring beskyttet af en række regler i forsikringslovgivningen, aftale-, forbrugeraftale- og markedsføringslovgivningen samt af generelle kon-

\footnotetext{
${ }^{137}$ Jf. Konsumentverket - Konsumentombudsmannen d.nr. 2005-02-03.

${ }^{138}$ Den absolutte reklamationsfrist angående mangler er nu 3 år efter den svenske KKPL (udredernes kommentar).
} 
traktsretlige grundsætninger. Visse af disse regler hviler på EU-harmonisering.

De forbrugerbeskyttende regler forpligter bl.a. forsikringsselskaberne og detailforretningerne til at give forbrugeren en række væsentlige oplysninger om forsikringen, herunder om dennes forhold til den eksisterende beskyttelse efter købelovgivningen og om risikoen for overlapning med en eventuel tegnet indboforsikring, dvs. dobbeltforsikring.

Derudover sikrer de forbrugerbeskyttende regler i et vist omfang, at der kan gribes ind, såfremt aftalen indgås på grundlag af vildledende oplysninger eller den indeholder urimelige vilkår.

Endvidere har forbrugerne i Danmark 14 dages fortrydelsesret; i de øvrige nordiske lande er forbrugerens fortrydelsesret begrænset til fjernsalg.

Forbrugeren nyder således allerede i dag en ikke ubetydelig retlig beskyttelse ved køb af tillægsforsikringer. Spørgsmålet er imidlertid, om reglerne i praksis er tilstrækkelige til at dæmme op for det grundlæggende problem ved tillægsforsikringer: At forbrugeren - på trods af oplysningsforpligtelser, civilretlige regler om vildledende oplysninger, fortrydelsesret med videre - ikke eller kun vanskeligt kan vurdere den reelle fordel forbundet med at købe en tillægsforsikring.

Tillægsforsikringerne befinder sig i et for de fleste forbrugere vanskeligt tilgængeligt krydsfelt mellem købe- og forsikringsret. Henset hertil og til de omtalte temmelig specielle praktiske forhold, hvorunder tillægsforsikringerne tegnes, synes der at være tale om beslutninger, hvor selv det relativt fintmaskede net af oplysningskrav med videre i praksis ofte ikke er i stand til at sikre forbrugeren et betryggende beslutningsgrundlag.

Konsekvensen heraf er, at der er en nærliggende risiko for, at forbrugeren ved tegningsbeslutningen vurderer, at usikkerheden om, hvorvidt forbrugeren har behov for en tillægsforsikring, medfører, at forbrugeren ikke tør undlade at købe tillægsforsikringen „for alle eventualiteters skyld“.

Det forhold, at forbrugeren i Danmark har en lovfæstet fortrydelsesret på 14 dage ved køb af en tillægsforsikring, giver selvsagt forbrugeren en mulighed for „at gå hjem og tænke sig om“, og på den baggrund eventuelt - efter have skaffet sig et overblik over forsikringen og dens reelle nytteværdi for forbrugeren - træde tilbage fra aftalen.

En fortrydelsesret for forbrugeren kan dog næppe i sig selv eliminere behovet for eventuelle yderligere tiltag i retning af at styrke forbrugerbeskyttelsen. I det omfang forbrugeren har vanskeligt ved at overskue tillægsforsikringsdækningen, herunder at sammenligne den med de køberetlige beskyttelsesregler og indboforsikringsdækningen, og/eller i det omfang forbrugeren fejlagtigt tror, at tillægsforsikringen giver en bedre beskyttelse end tilfældet er, har forbrugeren i sagens natur sjældent tilstrækkelig grund til at tage sin beslutning om at tegne tillægsforsikring op til revision og dermed til at udnytte fortrydelsesretten. 
Ud over det grundlæggende spørgsmål om, hvorvidt de gældende regler er tilstrækkelige til at sikre forbrugeren et fornødent grundlag for at træffe selve beslutningen om i det hele taget at købe en tillægsforsikring, peger rapporten i retning af, at der kan være en række andre forbrugerproblemer ved tillægsforsikringer. Disse andre problemer kan til en vis grad anskues uafhængigt af hovedproblemstillingen og kan derfor eventuelt kalde på særskilte løsninger.

Det gælder navnlig det problem, der ligger i, at der til udnyttelse af de fleste tillægsforsikringer er knyttet en selvrisiko, mens forbrugerens udnyttelse af den køberetlige reklamationsret er „gratis“. Hermed øges risikoen for, at funktionsfejl med videre, der i reklamationsperioden kan gøres gældende mod sælgeren som køberetlige mangler, overvæltes på forsikringen. Idet tillægsforsikringerne ofte indeholder vilkår om selvrisiko med videre, er forbrugeren på denne måde, gennem tegningen af tillægsforsikringen, i praksis udsat for at komme til at betale for at håndhæve de „gratis“ rettigheder, som forbrugerne har efter de køberetlige regler.

Af andre væsentlige problemer kan nævnes spørgsmålet om uklare og vildledende/urimelige vilkår i visse tillægsforsikringer, samt de i detailleddet tilsyneladende ikke sjældent forekommende problemer med at forstå og forklare forbrugerne det nærmere indhold af de tillægsforsikringer, de formidler.

\subsection{Retspolitiske løsningsmodeller}

Løsning af forbrugerproblemer gennem regeldannelse kan ske på en mere eller mindre intensiv måde. Den mest intensive løsning er selvsagt at gennemføre egentlige, bindende lovregler. I den anden ende af skalaen befinder sig regler, der ikke er bindende, for eksempel vejledninger, anbefalinger, retningslinjer og lignende, eller regler, der hviler på selv- eller samregulering, det vil sige udarbejdes og håndhæves i samarbejde med forbrugermyndigheder og -organisationer eller helt uden offentlig indblanding.

Som beskrevet i rapportens kapitel 4 gælder der i alle de nordiske lande en række generelle regler, der tilsammen - i teorien - giver forbrugeren en forholdsvis effektiv beskyttelse ved tegning af tillægsforsikringer. Der er tale om traditionelle, bindende lovregler, der kan håndhæves ved klagenævn og domstole. Når tillægsforsikringer alligevel giver anledning til en række problemer, kan dette tyde på, at reglerne ikke har den tilsigtede effekt i virkelighedens verden. Dette hænger muligvis sammen med de særlige forhold, hvorunder tillægsforsikringer tegnes.

I overvejelser af mulige retspolitiske initiativer bør derfor også indgå, i hvilket omfang vejen til det ønskede mål - at sikre forbrugeren et mere betryggende beslutningsgrundlag - går gennem yderligere lovgivningsinitiativer, og hvorvidt soft law regulering, der hviler på et samarbejde 
mellem forsikrings- og butiksbranchen og forbrugermyndigheder og organisationer kan være et egnet alternativ og/eller supplement.

Som alternativ/supplement til egentlige lovændringer kan det således overvejes i et samarbejde mellem erhvervs- og forbrugerorganisationer samt forbrugermyndigheder at opstille konkretiserede retningslinjer i form af „skabeloner“ for,

- dels hvordan en tillægsforsikring kan affattes for klart at opfylde de gældende lovkrav, begrænse fortolkningstvivl samt eliminere forekomsten af urimelige eller særlig byrdefulde vilkår;

- dels hvordan der kan gives skriftlig information om forholdet mellem tillægsforsikringsdækningen og forbrugerens minimumsbeskyttelse efter den køberetlige lovgivning samt nogle af de mest udbredte typer af indboforsikringsdækning, således at disse spørgsmål så vidt muligt belyses gennem praktisk relevante, konkrete eksempler.

En skabelon for tillægsforsikringsvilkår kunne dels omfatte en række overordnede principper, som alle tillægsforsikringer bør efterleve, dels indeholde forslag til affattelsen af de mest almindelige vilkår i en tillægsforsikring.

En „skabelonisering“ af tillægsforsikringsvilkårene ville bl.a fremme en vis standardisering (og sammenlignelighed) af tillægsforsikringsvilkår gennem opstilling af acceptable formuleringer af en række vilkår, som erfaringsmæssigt indgår i tillægsforsikirnger. På den anden side er det selvsagt vigtigt, at skabelonen ikke bliver en spændetrøje, som modvirker konkurrence på pris og dækningsomfang.

Idet der er tale om soft law regulering, ville det være frivilligt for de enkelte selskaber og detailforretninger, om de ville følge skabelonerne og de overordnede principper. Manglende overholdelse heraf ville dog efter omstændighederne kunne udgøre en overtrædelse af god markedsføringsskik og/eller god forsikringsskik og på den måde udløse fremadrettede sanktioner efter de offentligretlige regler i henholdsvis markedsføringsog forsikringslovgivningen. Samtidig ville „skabelonkontrakten“ kunne tjene som et udgangspunkt og sammenligningsgrundlag ved den civilretlige fortolkning og rimelighedsvurdering af „afvigende“ kontrakter.

De anførte bemærkninger tager i det store hele også sigte på den del af en soft law løsning, der kunne gå ud på udarbejdelse af vejledende „skabeloniseret“ skriftligt materiale til opfyldelse af oplysningspligten efter forsikringslovgivningen og markedsføringslovgivningen. Med særlig henblik herpå er der grund til tillige at påpege vigtigheden af, at materialet, ikke mindst den del, der angår forholdet mellem tillægsforsikringsdækningen og køberetlige regler samt indboforsikringsdækningen, kommer til at indeholde praktisk relevante, konkrete eksempler på indholdet af køberens rettigheder i henhold til købelovgivningen og på nogle typiske overlapningstilfælde. 
Generel information herom, som overlader det til den enkelte forbruger og eller salgspersonalet at fortolke forsikringsdækningen og købelovgivningen, bidrager i det praktiske liv antagelig kun i meget beskedent omfang til at forbedre forbrugerens beslutningsgrundlag.

I det følgende opridses (under 5.3) de væsentligste forbrugerproblemer forbundet med tillægsforsikringer, og der peges på nogle retspolitiske løsningsmuligheder.

\subsection{Forbrugerproblemer ved køb af tillægsforsikringer og nogle løsningsforslag.}

Det grundlæggende forbrugerproblem ved tegning af tillægsforsikringer i forbindelse med varekøb synes at være, at det er vanskeligt for den enkelte forbruger konkret at overskue, hvorvidt han eller hun har et reelt behov for tillægsforsikringen. Dette problem er, som allerede antydet (under 5.1), et produkt af en række enkeltstående - men dog tæt forbundne problemer, der i særlig grad synes at gøre sig gældende ved tegning af tillægsforsikringer ved varekøb. Mange af disse problemer synes i højere grad at hænge sammen med de særlige omstændigheder, hvorunder sådanne tillægsforsikringer sælges, end mangler i det retlige værn, der beskytter forbrugeren i forbindelse med forsikringstegningen. De væsentligste enkeltproblemer synes at være:

(1) Der kan sættes spørgsmålstegn ved, om detailleddet overhovedet egner sig til salg af så komplekse ydelser som tillægsforsikringer. Der kan således rejses spørgsmål om, hvorvidt den uddannelse, salgspersonalet i detailforretningerne får vedrørende tillægsforsikringer, lever op til de krav, der bør stilles til den, der skal formidle tillægsforsikringer til forbrugere. Der synes ikke sjældent hos salgspersonalet i detailleddet at være problemer med at forstå de tillægsforsik- ringer, det formidler, navnlig i relation til

- indhold (hvad er deres præcise dækningsomfang?)

- erstatningsopgørelse (hvordan opgøres den erstatning, forbrugeren har krav på, hvis forsikringsbegivenheden udløses?)

- tillægsforsikringsdækningens forhold til den relevante gældende lovgivning, navnlig købe- og forsikringsaftaleretlige regler. ${ }^{139}$

Eventuelle løsningsforslag: En radikal, men selvsagt effektiv løsning af hele problemkredsen ville være at forbyde, at aftale om tillægsforsikring indgås i detailforretning samtidig med køb af hovedproduktet. Dette ville imidlertid være et temmelig vidtgående skridt, der næppe kommer på

\footnotetext{
${ }^{139}$ Et fingerpeg om kendskabet blandt butiksansatte til indholdet af køberbeskyttelsen ved forbrugerkøb findes i den danske Forbrugerredegørelse 2005 kapitel 6.
} 
tale, før mindre vidtgående foranstaltninger er forsøgt. Sådanne mindre vidtgående foranstaltninger kunne bestå i et kvalitativt „løft“ af indholdet af forsikringsvilkårene og informationsmaterialet ad modum den under 5.2 skitserede „skabelonisering“. Denne burde som nævnt bl.a. sigte mod at give forbrugeren (og salgspersonalet) dækkende, eksemplificerende operationelle oplysninger om tillægsforsikringsdækningens indhold sammenlignet med køberetlige regler og nogle typiske indboforsikringer. Dette kunne eventuelt suppleres med et generelt krav om, at salgspersonalet skulle gennemgå informationsmaterialets konkrete eksempler på tillægsforsikringens dækning med forbrugeren.

(2) Problemerne hos salgspersonalet med at forstå og formidle de udbudte tillægsforsikringer kan bl.a. hænge sammen med, at tillægsforsikringer ofte er komplicerede eller uklart affattede - for eksempel vedrørende erstatningsopgørelse og dækningsomfang. Dette kan bidrage til at give forbrugerne et misvisende indtryk af deres reelle behov for at købe tillægsforsikringen. Det kan desuden forstærke forbrugernes problemer med at håndhæve den forsikringsdækning, som de har krav på i henhold til forsikringen, således som denne skal forstås i lyset af beskyttelsespræceptiv lovgivning, idet tillægsforsikringsvilkårene undertiden er affattet på en måde, som kan være egnet til at vildlede forbrugerne om deres retsstilling. ${ }^{140}$

Eventuelle løsningsforslag: En systematisk gennemgang og vurdering af de i praksis udbredte tillægsforsikringsvilkår foretaget af de forbrugerbeskyttende myndigheder med henblik på fremadrettet regulering af vildledende og i øvrigt urimelige aftalevilkår. En sådan foranstaltning kan foretages med hjemmel i den eksisterende offentligretlige aftalevilkårsreguleringslovgivning og/eller god skik regler. Ud over fjernelse af konstateret urimelige vilkår kunne en sådan gennemgang give basis for formulering af retningslinier for opstilling af „skabeloniserede modelvilkår“ som omtalt under 5.2.

(3) De under (1) og (2) nævnte problemer forstærkes af selve købssituationen, hvor forbrugerens beslutning om tegningen af tillægsforsikringen sker accessorisk til et netop besluttet køb af hovedproduktet og i løbet af ganske få minutter.

Eventuelle løsningsforslag: En kvalitativ forbedring af forbrugerens beslutningsgrundlag som nævnt ovenfor ad (1) og (2) kunne eventuelt kombineres med en generel fortrydelsesret for forbrugeren i de skabeloniserede aftalevilkår. ${ }^{141}$ En skrappere løsning kunne bestå i, at det forbed-

\footnotetext{
${ }^{140}$ Se nærmere ovenfor under 4.7.

${ }^{141}$ Den danske FAL indeholder som nævnt (under 4.4) en generel fortrydelsesret angående forbrugerforsikringer. Det bemærkes i øvrigt, at de ovenfor (under 5.1) anførte skeptiske bemærkninger angående den eksisterende danske fortrydelsesrets praktiske betydning i en tillægsforsikringssammenhæng navnlig må ses i lyset af, at en fortrydelsesret ikke i sig selv giver forbrugeren et bedre beslutningsgrundlag. Hvis der sker et kvalitativt "løft” og operationalisering af de oplysninger, der
} 
rede beslutningsgrundlag ikke blev kombineret med en fortrydelsesret, men med et vilkår om, at tillægsforsikringsaftalen inden en vis frist skulle bekræftes af forbrugeren for at forblive i kraft.

(4) Detailforretningernes relativt store økonomiske gevinst ved formidling af tillægsforsikringer kan give uheldige incitamenter til

- at overdrive tillægsforsikringens fordele over for forbrugeren,

- at anvende køberetlige regler restriktivt for derigennem at øge salget af tillægsforsikringer, og

- at underinformere forbrugeren om køberetlige regler om mangler og om den mulige indboforsikringsdækning i tilfælde, hvor tillægsforsikringens „merdækning“ er beskeden.

Eventuelle løsningsforslag: Et krav om obligatorisk oplysning om detailforretningens økonomiske interesse i tegning af tillægsforsikring vil advare forbrugeren om, at der er tale om afsætning og ikke rådgivning. ${ }^{142}$ Ønsker man at sikre, at oplysningen skal virke efter hensigten, bør oplysningspligten formentlig tillige omfatte en angivelse af den økonomiske interesses styrke. ${ }^{143}$ En mere radikal løsning ville bestå i at sætte et økonomisk loft for detailforretningens vederlag.

(5) Prisen for tillægsforsikringer er ofte forholdsvis høj sammenlignet med prisen for hovedproduktet, og forbrugeren kan, også i de tilfælde, hvor tillægsforsikringen giver forbrugeren væsentlige, reelle fordele, have vanskeligt ved at overskue, hvorvidt prisen afspejler fordelene, idet dette forudsætter, at den enkelte forbruger, allerede ved forsikringstegningen i detailforretningen, skaffer sig eller bibringes en forholdsvis klar forestilling om forsikringsdækningens omfang, herunder den „merdækning“ den giver sammenlignet med køberetlige regler og forbrugerens eventuelle indboforsikring.

Eventuelle løsningsforslag: En forbedring af forbrugerens beslutningsgrundlag som skitseret under $5.2 \mathrm{og}$ ad (1) - (3) ville bidrage til at begrænse også det her omtalte problem, som desuden må ses som en faktor, der kan være med til at forstærke den under (4) omtalte uheldige incitamentsstruktur, som i vist omfang synes indbygget i aftalerne mellem detailkæde og forsikringsselskab. I øvrigt må det antages, at den beløbsmæssige grænse på 500 euro (årlig præmie), som er en af betingelserne for at være undtaget fra forsikringsformidlingsdirektivet 2002/92/EF,

gives til forbrugeren, kan en fortrydelsesret medvirke til, at forbrugeren får bedre mulighed for i fred og ro at tage stilling til spørgsmålet på et mere betryggende grundlag.

${ }^{142}$ Dette svarer til, hvad der gælder i efter den danske forsikringsformidlingslov § 34, stk. 2, se nærmere under 4.2.

${ }^{143}$ Efter den danske forsikringsformidlingslov § 34, stk. 2, skal denne kun oplyses på forbrugerens forespørgsel. 
også sætter et naturligt loft for prisen på en tillægsforsikring ved varekøb. ${ }^{144}$

Ønskes videregående regulering af prisen for en tillægsforsikring, kunne det eventuelt ske ved i det omtalte „skabeloniserede“ informationsmateriale at opstille en almindelig vejledende tommelfingerregel for, hvor meget prisen for tillægsforsikringen bør være i \% af prisen for hovedproduktet. Dette kunne især få betydning ved tillægsforsikringer for små billige forbrugerprodukter.

(6) Ud over problemerne relateret til forbrugerens mangelfulde beslutningsgrundlag udgør det et grundlæggende forbrugerpolitisk problem, at tillægsforsikringer på grund af regler om selvrisiko med videre skaber risiko for, at forbrugerkøbere gennem tegning af tillægsforsikringer i praksis kommer til at betale for at nyde godt af de rettigheder, de har efter køberetlige regler, og som de allerede har betalt for gennem købesummen for hovedydelsen.

Eventuelle løsningsforslag: En løsning kunne eventuelt bestå i et forbud mod tillægsforsikringsaftalevilkår, som fastsætter selvrisiko i tilfælde af dækning af funktionsfejl med videre i en periode svarende til den absolutte reklamationsfrist i Danmark (2 år) og måske Sverige (3 år). I Finland (hvor der ikke er nogen absolut reklamationsfrist) samt i Island og Norge, hvor reklamationsfristen i det overvejende antal praktiske tilfælde er 5 år, kunne et forbud mod selvrisiko eventuelt sættes til 2 eller 3 år, svarende til den periode, hvor det gennemsnitligt set kan forventes, at forbrugerens bevismæssige fordele ved aktivering af tillægsforsikringen frem for køberetlige mangelsregler kan have væsentlig praktisk betydning.

(7) Under hensyn til, at forbrugeren allerede ved tegningen betaler for hele den forventede forsikringstid på typisk 3 eller 5 år, bliver spørgsmålet om tilbagebetaling af en del af præmien i tilfælde af forsikringens førtidige ophør relevant i højere grad end ved forbrugerforsikringer i almindelighed,

- dels fordi forbrugeren typisk allerede ved tegningen har betalt for hele den forventede forsikringsperiode, og derfor i givet fald kan hævdes ikke fuldt ud at modtage modydelsen, og

- dels fordi sandsynligheden for forsikringens førtidig ophør på grund af den forsikrede interesses ophør forekommer at være noget større med deraf følgende skuffelse af forbrugerens forventninger. ${ }^{145}$

Eventuelle løsningsforslag: På grund af spørgsmålets ikke ubetydelige praktiske betydning kan det overvejes at stille et almindeligt krav om, at

\footnotetext{
${ }^{144}$ Direktivet er nærmere.omtalt under 4.1.2.

${ }^{145}$ Se nærmere om den retlige problemstilling ovenfor under 4.6.
} 
tillægsforsikringsvilkårene og/eller skriftligt informationsmateriale bør indeholde en eksplicit angivelse af, hvilke omstændigheder der kan føre til forsikringens førtidige ophør, og af, hvilken betydning dette har for forbrugerens mulighed for få en del af præmien tilbagebetalt. Spørgsmålet herom synes velegnet til opstilling af god skik-retningslinjer på grundlag af en samlet vurdering af spørgsmålet. ${ }^{146}$

${ }^{146} \mathrm{Jf}$. i samme retning om forbrugerforsikringer generelt Ivan Sørensen: Udredning om bedre forbrugerbeskyttelse ved private forsikringer i Danmark s. 66; afgivet til Forbrugerombudsmanden i maj 2001 og tilgængelig på www.forbrug.dk/klage/love/mfl/ophaevede-retningslinier-ogvejledninger/minimumsstandarder for forsikringsselskaber. 



\section{Tiivistelmä}

Tämä raportti on laadittu osana Tanskan kuluttajaviraston (Forbrugerstyrelsen) alaista pohjoismaista projektia "Lisävakuutukset tavaraostojen yhteydessä”, joka on toteutettu Pohjoismaiden ministerineuvoston myöntämällä tuella.

Projektin ja raportin tarkoituksena on analysoida Pohjoismaissa tavaraostojen yhteydessä otettuja lisävakuutuksia. Raportti sisältää lisävakuutusmarkkinoiden kartoituksen, analyysin kuluttajien lisävakuutusten tuntemuksesta ja tarpeesta sekä oikeuspoliittisia pohdintoja.

Raportissa lisävakuutuksilla tarkoitetaan vakuutuksia, jotka liittyvät tiettyyn tuotteeseen, jonka kuluttaja - vakuutuksen kanssa samanaikaisesti - ostaa vähittäiskaupasta. Muut vakuutukset, jotka koskevat irtaimistoa mutta joita ei osteta vähittäiskaupasta, esimerkiksi yleiset irtaimistovakuutukset tai vakuutusten etämyynti, jäävät projektin ulkopuolelle.

Raportin tiedot perustuvat muun muassa projektiryhmän jäsenten tai ministeriöiden/hallitusten, valituslautakuntien, asiaankuuluvien etujärjestöjen, lehtiartikkelien, tv-lähetysten ja Internetin kautta saatavilla oleviin tai kerättyihin tietoihin.

Tutkijoiden käytettävissä olevat tiedot viittaavat siihen, että pohjoismaiset kuluttajat hankkivat lisävakuutuksen noin kolmasosassa tekemistään ostoksista, joiden yhteydessä lisävakuutusta tarjotaan. Se tarkoittaa, että Pohjoismaissa otetaan joka vuosi 3-3,5 miljoonaa lisävakuutusta. Myynnin tähänastista kokonaisliikevaihtoa on vaikea arvioida, etenkin kun alalta ei ole saatavilla virallisia lukuja. Vuotuinen kokonaisliikevaihto on joka tapauksessa epäilemättä yli miljardi Tanskan kruunua. Markkinat ovat näin ollen huomattavat.

Raportti osoittaa, että Tanskan, Norjan ja Ruotsin lisävakuutusmarkkinat ovat luonteeltaan samanlaiset ja kuluttajien ongelmat ovat yleisesti ottaen samoja. Suomen ja Islannin tilanteesta on vain niukasti tietoja. Eri Pohjoismaiden kuluttajalainsäädäntöjen väliset erot, kuten kauppalain mukaisen ehdottoman reklamaatioajan pituus tai palautusoikeus vakuutusten myynnissä, kuvastuvat luonnollisesti eri maiden lisävakuutussopimuksissa.

Lisävakuutuksia myydään lähinnä kotitaloustuotteiden, kodinkoneiden ja useimpien kulutuselektroniikkalaitteiden yhteydessä. Lisävakuutuksia myydään kuitenkin myös muuntyyppisille tuotteille, kuten matkapuhelimille ja silmälaseille.

Lisävakuutuksia myydään vähittäiskaupassa yhdessä tuotteen kanssa, johon vakuutus liittyy. Lisävakuutus maksetaan samanaikaisesti päätuotteen kanssa. Tuotteen ostopaikan myyjä toimii välittäjänä eli myy vakuutuksen vakuutusyhtiön puolesta. Myyntihenkilöstön on näin ollen annet- 
tava lisävakuutuksesta tarvittavat tiedot, kuten tiedot vakuutusturvasta, voimassaolosta suhteessa kauppalain mukaiseen reklamaatio-oikeuteen ja suhteesta kuluttajan muihin vakuutuksiin.

Vähittäiskauppa saa vakuutusyhtiöltä (joka on lisävakuutuksen ottavan kuluttajan sopimuskumppani) lisävakuutusten välittämisestä provision. Provisio on usein melko suuri, mikä on luonnollisesti vähittäiskaupassa lisäkannustin lisävakuutusten myynnille tavaraoston yhteydessä.

Lisävakuutuksia myydään monilla nimillä. Ne voidaan jakaa kahteen ryhmään, perusvakuutuksiin ja laajennettuihin vakuutuksiin. Eri lisävakuutusten välillä voi olla huomattaviakin eroja.

Peruslisävakuutus kattaa harvoin merkittävässä määrin muuta kuin ne virheet ja puutteet, joista kuluttaja voi reklamoida kauppalain reklamaatiosäännösten perusteella. Ero on tavallisesti siinä, että lisävakuutuksen voimassaoloaika voi olla pidempi kuin reklamaatioaika. Joissakin tapauksissa lisävakuutus kattaa kuitenkin vahingot tai muut vakuutustapaukset, joita reklamaatio-oikeus ei virheen yhteydessä kata. Sen sijaan lisävakuutuksessa on yleensä muita ehtoja, jotka koskevat esimerkiksi arvonalennusta ja omavastuuta ja joista on todellisuudessa kuluttajalle vähemmän hyötyä kuin kauppalain reklamaatiosäännöksistä.

Peruslisävakuutuksiin verrattuna laajennetuissa lisävakuutuksissa on tyypillisesti laajempi vakuutusturva, pienempi omavastuu tai ei lainkaan omavastuuta, pienempi tai olematon hankinta-arvon aleneminen taikka muita etuja. Laajojen lisävakuutusten laajempi vakuutusturva tarkoittaa tietysti myös sitä, että ne ovat kalliimpia.

Lisävakuutuksen hinta on yleensä 10-20 \% vakuutetun tuotteen hinnasta. Halvempien kuluttajatuotteiden lisävakuutus voi kuitenkin olla suhteellisesti laskettuna huomattavasti kalliimpi, kun taas erittäin kalliiden kuluttajatuotteiden lisävakuutus voi olla huomattavasti halvempi.

Lisävakuutuksia tarjotaan useimmiten suurissa vähittäiskauppaketjuissa ja nimenomaan niissä, jotka myyvät kaikentyyppisiä kodinkoneita ja/tai kulutuselektroniikkaa. Monet lisävakuutuksia välittävät vähittäiskauppaketjut toimivat useissa Pohjoismaissa. Samoin taustalla olevat vakuutusyhtiöt, joiden kanssa kuluttaja tekee - vähittäiskaupan välityksellä - vakuutussopimuksen, ovat eri Pohjoismaissa yleensä samoja. Vakuutusyhtiöitä, jotka tarjoavat lisävakuutuksia vähittäiskaupan kanssa yhteistyössä, näyttää olevan suhteellisen vähän.

Eri tiedot viittaavat siihen, että lisävakuutuksia hyödynnetään 30-40 prosentissa tapauksista, joissa vakuutus on otettu. Tuotteita, joissa lisävakuutuksia hyödynnetään eniten, ovat korkeimpien hintaluokkien televisiot, pesukoneet/kuivausrummut ja astianpesukoneet. Tuotteita, joissa ostettua lisävakuutusta hyödynnetään harvemmin, ovat liedet, jääkaapit ja pakastimet sekä alimpien hintaluokkien musiikkilaitteistot.

Lisävakuutuksissa on olennaista se, miten laajasti ne tuottavat kuluttajalle todellista etua suhteessa "riskiturvaan", joka kuluttajalla saatujen tietojen mukaan jo on virheitä koskevien kauppalain säännösten, mahdol- 
lisen myyjän/tuottajan antaman takuun ja Pohjoismaissa suurimmalla osalla kotitalouksista olevan irtaimistovakuutuksen perusteella. Näitä kysymyksiä käsitellään raportin luvussa 3.

Tosiasiassa tarjottavien lisävakuutusten ja kauppalain virheitä koskevien säännösten vertailusta voidaan tehdä sellainen yhteenveto, että tavaran laadun ollessa puutteellinen lisävakuutukset eivät yleensä tarjoa kuluttajalle laajempaa turvaa kuin kauppalain säännökset, ennen kuin ostosta on kulunut määritettyä pidempi aika. Miten pitkästä ajasta kulloinkin on kyse, riippuu ensisijaisesti tavaran luonteesta. Mahdollinen „lisäturva“ voi koostua seuraavista tekijöistä:

- Lisävakuutusaika on pidempi kuin kauppalainsäädännön ehdoton reklamaatioaika eli kaksi vuotta (Tanska), kolme vuotta (Ruotsi), viisi (joissain tapauksissa kuitenkin vain kaksi) vuotta (Islanti ja Norja). Suomessa ei ole lainkaan ehdotonta reklamaatioaikaa.

- Kun ostosta on kulunut yli kuusi kuukautta, kuluttaja voi olosuhteiden mukaan saada lisävakuutuksen perusteella tietyn todistettavan edun, joka johtuu siitä, että olennainen, tosiasioihin perustuva epäily toimintavian syystä ym. luetaan juridisesti kuluttajan hyväksi.

- Kuluttaja ei kuitenkaan saa mainituista seikoista johtuvaa lisäturvaa, jos tavaralla on myyjän tai kolmannen osapuolen myöntämä takuu. Vakuutusturva ei myöskään yleensä vedä vertoja "turvalle”, jonka kuluttaja voi saada kauppalain säännösten nojalla. Tämä johtuu osin siitä, että lisävakuutuksissa on usein esimerkiksi omavastuuta ja arvonalenemista koskevia sääntöjä, ja osin siitä, vakuutuslainsäädännön mukaan korvaus ei saa olla tappiota suurempi.

- Lisävakuutus kattaa joissakin mutta ei kaikissa tilanteissa tietyssä määrin myös ulkoisen tekijän aiheuttamat vahinkotapahtumat, jotka ovat sattuneet riskin siirryttyä kuluttajalle (ilman, että väitettäisiin myyjän laiminlyöneen sopimuksenmukaisia velvollisuuksiaan). Tämä on kuluttajan etu, mikäli esimerkiksi kuluttajan irtaimistovakuutus kattaa tällaiset vahinkotapahtumat.

Kun lisävakuutuksen vakuutusturvaa verrataan irtaimistovakuutuksen vakuutusturvaan, voidaan ensinnäkin todeta, että irtaimistovakuutus kattaa tyypillisesti palo- ja vesivahingot, varkaudet ja vahingonteot eli ulkoiset häiriöt, jotka vahingoittavat tai tuhoavat tavaroita. Lisävakuutukset sen sijaan kattavat tyypillisesti toimintaviat, rikkoutumiset ja vastaavat eli itse tavarassa olevan virheen. Lähtökohtaisesti näissä kahdessa vakuutuslajissa ei ole päällekkäisyyksiä.

Tämä kuva kuitenkin muuttuu usein käytännössä irtaimisto- ja lisävakuutusten monien valinnanmahdollisuuksien vuoksi, jotka todellisuudessa usein tasoittavat näiden kahden erityyppisen vakuutuksen eroja. Yksittäisen kuluttajan voi siksi olla vaikea saada selville, mitä etuja lisävakuutus todellisuudessa tarjoaa kuluttajalla jo ennestään olevan turvan lisäksi. 
Kun lisävakuutussopimuksia tehdään erityisolosuhteissa vähittäiskaupassa tavaraoston lisänä, kuluttajan tilanne vaikeutuu tässä mielessä entisestään.

Tästä herää kysymys, tarjoavatko voimassa olevat kuluttajansuojasäännökset riittävän perustan kuluttajien päätöksenteolle silloin, kun on päätettävä lisävakuutuksen ostamisesta. Tätä kysymystä käsitellään raportin luvussa 4.

Pohjoismaisia kuluttajia suojaavat lisävakuutusta ostettaessa tietyt vakuutuslainsäädännön, sopimus-, kuluttajasopimus- ja markkinointilainsäädännön säännökset sekä yleiset sopimusoikeudelliset perusteet.

Kuluttajansuojasäännökset velvoittavat muun muassa vakuutusyhtiöt ja vähittäiskauppayritykset antamaan kuluttajalle tietyt tärkeät tiedot vakuutuksesta, kuten tiedot sen suhteesta kauppalainsäädännön nojalla olemassa olevaan vakuutusturvaan ja mahdollisesta päällekkäisyydestä irtaimistovakuutuksen kanssa eli kaksinkertaisen vakuuttamisen riskeistä.

Lisäksi kuluttajansuojasäännökset varmistavat tietyssä laajuudessa, että asiaan voidaan puuttua, jos sopimus tehdään harhaanjohtavien tietojen perusteella tai sen ehdot ovat kohtuuttomat. Sen lisäksi Tanskassa kuluttajilla on 14 päivän palautusoikeus; muissa Pohjoismaissa kuluttajien palautusoikeus on rajoitettu etämyyntiin.

Kuluttajilla on siis jo nyt merkittävä lainsäädännöllinen suoja, kun he ottavat lisävakuutuksen. Kysymys kuuluu kuitenkin, takaavatko säännökset käytännössä riittävän perustan, kun kuluttajan on arvioitava, onko lisävakuutuksen ostamisesta konkreettisessa tilanteessa todellista hyötyä. Kuluttajaongelmia koskevaa oikeuspoliittista kysymystä ja joitakin eri ratkaisumahdollisuuksia käsitellään raportin luvussa 5.

Lisävakuutukset ovat useimmille kuluttajille vaikeasti hahmotettavassa kauppa- ja vakuutusoikeuden risteyskohdassa. Kun otetaan huomioon tähänastinen tilanne ja mainitut melko erikoiset käytännön olosuhteet, joissa lisävakuutussopimukset tehdään, näyttää olevan kyse päätöksistä, joissa tiedonantovaatimuksen yms. suhteellisen tiukka seula ei käytännössä useinkaan takaa kuluttajalle turvallista päätöksenteon perustaa.

Tämän seurauksena on helposti vaarana, että jos kuluttaja on vakuutuksesta päättäessään epävarma siitä, tarvitseeko hän lisävakuutusta, hän ei uskalla olla ostamatta lisävakuutusta „kaiken varalta“. Moni asia viittaa siihen, että tarvitaan ehkä oikeuspoliittisia toimia sen varmistamiseksi, että pohjoismaiset kuluttajat ovat riittävän suojattuja allekirjoittaessaan lisävakuutussopimuksia.

Luvussa 5 osoitetaan lopuksi eri ongelma-alueita ja esitetään mahdollisia ratkaisuehdotuksia.

Yleisesti ottaen todetaan, että varsinaisten lakimuutosten vaihtoehtona tai lisänä on harkittava konkreettiset suuntaviivat antavien „mallien“ laatimista yhteistyössä ammatti- ja kuluttajajärjestöjen sekä kuluttajaviranomaisten seuraavista aiheista: 
- Lisävakuutuksen ehdot, joihin sisältyy joitakin yleisiä periaatteita, joita kaikissa lisävakuutuksissa on noudatettava, ja ehdotuksia lisävakuutuksen yleisimpien ehtojen laatimiseksi.

- Kirjallinen informaatioa lisävakuutusturvan ja kuluttajan kauppalainsäädännön mukaisen vähimmäisturvan välisestä suhteesta, sekä joitakin yleisimpiä irtaimistovakuutusturvan tyyppejä, niin että näitä kysymyksiä valaistaan mahdollisimman laajasti asiaankuuluvilla, konkreettisilla käytännön esimerkeillä.

Lisävakuutuksen ehtojen „mallintaminen“ voisi muun muassa edistää tietynlaista standardointia (ja vertailukelpoisuutta), kun laaditaan hyväksyttävä muotoilu ehdoista, joita lisävakuutuksissa kokemuksen mukaan on. Toisaalta on luonnollisesti tärkeää, että mallista ei tule pakkopaitaa, joka vaikuttaa haitallisesti kilpailuun hinnasta ja vakuutusturvan kattavuudesta.

Koska kyse on niin sanotusta pehmeästä sääntelystä ("soft law”), mallien ja yleisperiaatteiden noudattaminen olisi yrityksille ja vähittäiskaupoille vapaaehtoista. Niiden noudattamisen laiminlyönti saattaisi kuitenkin olla joissakin tilanteissa hyvän markkinointitavan ja/tai hyvän vakuutustavan vastaista, mistä voisi markkinointi- ja vakuutuslainsäädäntöä koskevien julkisoikeudellisten säännösten perusteella seurata sanktioita.

Yksi erityinen kuluttajapoliittinen ongelma, johon luvussa 5 viitataan, on se, että lisävakuutuksissa on omavastuuta koskevien säännösten vuoksi riskinä, että kuluttajat maksavat lisävakuutuksen allekirjoittamalla käytännössä siitä, että he käyttävät oikeuksiaan, jotka heillä jo on kauppalain säännösten perusteella ja joista he ovat jo maksaneet päätuotteen ostosummassa.

Yhtenä mahdollisena ratkaisuna raportissa ehdotetaan, että lisävakuutuksiin kiellettäisiin lisäämästä ehtoja, joilla määritettäisiin toimintavian ja vastaavan korvaamisessa omavastuuajaksi aika, joka vastaa virheitä koskevaa ehdotonta reklamaatioaikaa Tanskassa (kaksi vuotta) ja mahdollisesti Ruotsissa (kolme vuotta). Suomessa, missä ei ole ehdotonta reklamaatioaikaa, sekä Islannissa ja Norjassa, joissa reklamaatioaika on useimmissa käytännön tilanteissa viisi vuotta, omavastuukielto voisi olla kaksi tai kolme vuotta sen mukaan, miten pitkällä ajanjaksolla keskimäärin voidaan olettaa kuluttajalla olevan lisävakuutusturvasta todistettavasti sellaista oleellista käytännön etua, jota kauppalain virheitä koskevat säännökset eivät tarjoa. 



\section{Samantekt}

Skýrsla pessi er unnin sem páttur í norrænu verkefni sem heyrir undir dönsku Neytendastofnunina (Forbrugerstyrelsen) undir heitinu „Viðbótartryggingar við vörukaup“. Verkefnið er unnið með fjárstuðningi frá Norræna ráðherraráðinu.

Verkefnið og skýrslan hafa pað að markmiði að skilgreina markaðsumhverfið með tilliti til viðbótartrygginga við vörukaup á Norðurlöndum. раð hefur að geyma kortlagningu markaðsins fyrir viðbótartryggingar, ásamt greiningu á bekkingu neytandans og pörf hans fyrir viðbótartryggingar auk réttarpólitískra hugleiðinga.

Með viðbótartryggingum er í skýrslunni átt við tryggingu sem tengist ákveðinni vöru sem neytandinn kaupir í smásöluverslun ásamt tryggingunni. Aðrar tryggingar sem snerta lausafjármuni en eru ekki keyptar í smásöluverslun falla utan verkefnisins, s.s. venjulegar innbústryggingar eða fjarsala á tryggingum.

pau gögn sem liggja til grundvallar skýrslunni byggjast á upplýsingum sem eru aðgengilegar eða hefur verið aflað af pátttökuaðilum verkefnishópsins eða koma frá ráðuneytum/stofnunum, kvörtunarnefndum, hagsmunasamtökum, greinum í dagblöðum, sjónvarpsútsendingum, upplýsingum aðgengilegum á Internetinu o.fl.

pær upplýsingar sem eru aðgengilegar skýrsluhöfundum benda til pess að norrænir neytendur kaupi viðbótartryggingu í u.p.b. 1/3 allra kauptilvika par sem viðbótartrygging er í boði. Detta felur í sér að á hverju ári eru keyptar 3-3,5 milljónir viðbótartrygginga á Norðurlöndum. Erfitt er að meta pau samanlögðu viðskipti sem pessi sala leiðir af sér, par sem ekki liggja fyrir opinberar, aðgengilegar tölur frá starfsgreinunum. Óvarlegt er að leggja til grundvallar að um sé að ræða árlega heildarveltu upp á að minnsta kosti en 1 milljarð DKK en ljóst er að markaðurinn er töluvert stór.

Skýrslan leiðir í ljós að hvað viðvíkur Danmörku, Noregi og Svípjóð hefur markaðurinn fyrir viðbótartryggingar sömu einkenni, og að á heildina litið eru par ríkjandi sömu neytendavandamál. Aðeins liggja fyrir takmarkaðar upplýsingar um aðstæður í Finnlandi og á Íslandi. Sá munur sem er til staðar á milli viðkomandi neytendalöggjafar innan Norðurlanda, t.d. með tilliti til lengdar kaupréttarlegs kvörtunarfrests eða tilvistar iðrunarréttar vegna sölu á tryggingum, endurspeglast eðlilega í samsetningu viðbótartrygginga í einstökum löndum.

Viðbótartryggingar eru fyrst og fremst seldar í tengslum við heimilistæki og flestar tegundir raftækja. Viðbótartryggingar eru einnig seldar 
með ýmsum öðrum tegundum vara, par með töldum farsímum og gleraugum.

Viðbótartryggingar eru seldar á smásölustigi ásamt peirri vöru sem tryggingin tengist. Greitt er fyrir viðbótartrygginguna samtímis pví að greitt er fyrir aðalvöruna. Viðbótartryggingar eru seldar eða peim miðlað, p.e.a.s. til peirra er stofnað í nafni tryggingafélagsins af afgreiðslufólki pví sem starfar í smásöluversluninni, par sem varan er keypt. Allar nauðsynlegar upplýsingar um viðbótartrygginguna, gildissvið hennar og gildistíma í hlutfalli við kvörtunarrétt samkvæmt kaupalögum, tengsl hennar við aðrar tryggingar neytandans o.s.frv. skulu pannig vera veittar af starfsfólki verslunarinnar.

Fyrir að miðla viðbótartryggingu piggur smásöluverslunin umboðslaun frá tryggingafélaginu (sem er ákveðinn hluti pess sem neytandinn greiðir í tengslum við viðbótartrygginguna). Umboðslaunin eru oft umtalsverð, sem vafalaust verður til pess að örva smásöluverslunina til pess að selja viðbótartryggingar í tengslum við vörukaup.

Margar tegundir viðbótartrygginga eru til sölu. Pær má flokka kerfisbundið niður í tvo höfuðflokka, staðlaða tryggingu annars vegar og tryggingu með útvíkkuðu gildissviði hins vegar. Hægt er að greina mjög mikinn mun á útfærslu hinna einstöku viðbótartrygginga.

Gildissvið stöðluðu viðbótartryggingarinnar víkur sjaldnast verulega langt frá peim göllum og annmörkum, sem neytandinn getur kvartað yfir samkvæmt kvörtunarreglum kaupalaga. Dæmigert er að munurinn liggi í pví að viðbótartryggingin geti haft lengri gildistíma en kvörtunarfresturinn varir. Í nokkrum tilfellum nær viðbótartryggingin pó til tjóna eða annarra tryggingatilvika, sem kvörtunarrétturinn vegna galla nær ekki til. Á hinn bóginn eru að jafnaði aðrir skilmálar í viðbótartryggingunni, svo sem varðandi afskriftir og sjálfsáhættu sem í raun leiða til pess að neytandinn stendur verr að vígi en samkvæmt kvörtunarreglum kaupalaga.

Í samanburði við hina stöðluðu viðbótartryggingu hafa hinar dæmigerðu útvíkkuðu viðbótartryggingar víðtækara gildissvið, minni eða enga sjálfsáhættu, minni eða engin afföll af kaupvirðinu eða aðra kosti. Auknu gildissviði er pó að sjálfsögðu mætt með hærra verði fyrir hinar útvíkkuðu viðbótartryggingar.

Verðið fyrir viðbótartryggingu svarar í flestum tilfellum til 10-20\% af verði hinnar tryggðu vöru. Fyrir neytendavörur í ódýrari kantinum getur viðbótartryggingin pó verið hlutfallslega nokkru dýrari, á sama hátt og að hún getur verið hlutfallslega nokkru ódýrari fyrir mjög dýrar neytendavörur.

Viðbótartryggingar eru mest útbreiddar meðal stórra verslanakeðja á smásölumarkaði, sérstaklega peirra sem bjóða margar tegundir heimilistækja og/eða raftækja. Margar peirra verslanakeðja sem miðla viðbótartryggingum eru samnorrænar. Sömuleiðis eru pau dæmigerðu tryggingafélög sem standa að baki tryggingunum, sem neytandinn, í gegnum 
smásöluverslunina, efnir til tryggingasamningsins við, pau sömu yfir öll Norðurlönd. Sá hópur tryggingafélaga sem býður viðbótartryggingar í samvinnu við smásölustigið lítur út fyrir að vera tiltölulega pröngur.

Ýmsar upplýsingar benda til pess að neytendur notfæri sér viðbótartryggingar í 30-40\% peirra tilfella, par sem boðið er upp á tryggingu. Đær vörur par sem fólk notfærir sér oftast viðbótartryggingu eru sjónvörp í hæstu verðflokkunum, pvottavélar/purrkarar og uppbvottavélar. pær vörur sem fólk kaupir sér sjaldnast viðbótartryggingu með eru eldavélar, kæli- og frystiskápar auk hljómtækja í lægstu verðflokkum.

Úrslitabátturinn varðandi viðbótartryggingar er í hve miklum mæli pær veita neytandanum raunverulegt hagræði, með tilliti til peirrar verndar sem neytandanum er pegar tryggð með reglum kauparéttar um vörugalla, ábyrgð seljandans/framleiðandans auk peirrar innbústryggingar sem langstærsti hluti heimila á Norðurlöndum hefur. Fjallað er nánar um pessi atriði í kafla 3 í skýrslunni.

Samanburð á milli viðbótartrygginga sem í reynd eru skuldbindandi og hinna kauparéttarlegu reglna um galla má gera með samantekt, par sem dæmigerðar viðbótartryggingar veita neytandanum ekki meira öryggi í tilfelli gæðabrests en kaupalagalögin gera fyrr en liðinn er visst langur tími frá kaupunum. Hve langur tími pað er sem um ræðir er fyrst og fremst komið undir tegund vörunnar. Detta „viðbótaröryggi“, sem um getur verið að ræða, getur falist í pví:

- Að viðbótartryggingatíminn er lengri en hinn ákveðni kvörtunarfrestur kaupalaganna, p.e. 2 ár (Danmörk), 3 ár (Svípjóð), 5 ár (eftir kringumstæðum pó aðeins 2 ár) (Ísland og Noregur); í Finnlandi er ekki um að ræða neinn ákveðinn kvörtunarfrest.

- Í krafti viðbótartryggingarinnar getur neytandinn, að liðnum meira en 6 mánuðum frá kaupum, og í ljósi kringumstæðna hverju sinni, náð fram vissu hagræði með framlagningu sönnunargagna sem felst í pví að vafinn sem tengist pví hver orsök pess er að varan virkar ekki sem skyldi, og fleira af lögfræðilegum toga, kemur neytandanum til góða.

- Neytandinn nær bó ekki fram bví aukna öryggi, sem fram kemur í punktunum hér að ofan, að pví marki sem ábyrgðarskuldbinding seljandans eða priðja aðila nær til vörunnar. Dar fyrir utan stenst gildissvið tryggingarinnar venjulega ekki samanburð við pað „,gildissvið“ sem neytandinn getur náð fram samkvæmt reglum kaupalaganna. Petta er að hluta til háð pví að viðbótartryggingarnar fela oft í sér reglur um eigináhættu, afskriftir o.fl., og að hluta til auðgunarbann tryggingaréttar.

- Dau atvik sem eru bætt skv. skilmálum viðbótartryggingar eru í sumum tilfellum einnig utanaðkomandi atvik sem gerast eftir að áhættan flyst yfir til neytandans (án pess að pað sé vegna pess að seljandinn hafi vanefnt skuldbindingar sínar samkvæmt samningnum). 
Detta er kostur fyrir neytandann, nema slík atvik falli undir gildissvið innbústryggingar neytandans o.fl.

Sé gildissvið viðbótartryggingar borið saman við gildissvið innbústryggingar, er hægt að fullyrða að dæmigert gildissvið innbústryggingar eru bruna- og vatnstjón, bjófnaður og skemmdarverk, p.e. pegar slík atvik valda tjóni eða skemmdum á hlutnum. Dæmigert gildissvið viðbótartrygginga á hinn bóginn er að hluturinn virkar ekki sem skyldi, skemmd eða pví um líkt, b.e.a.s. galli á hlutnum sjálfum. Dví er ekki gengið út frá pví að um sé að ræða skörun á milli pessara tveggja tegunda trygginga.

pessi mynd breytist engu að síður oft í framkvæmd sem afleiðing hinna mörgu valmöguleika sem bæði innbús- og viðbótartryggingar bjóða upp á, og sem í reynd jafna oft út muninn á milli pessara tveggja tegunda trygginga. Hinn einstaki neytandi getur af beim sökum átt í erfiðleikum með að gera sér grein fyrir pví hvaða viðbót tryggingin veitir í raun og veru vegna peirrar verndar sem neytandinn er fyrirfram aðnjótandi að. pær sérstöku aðstæður sem ríkja par sem viðbótartryggingarnar standa til boða á smásölustiginu, p.e. sem stuðningspáttur vegna kaupa á umræddri vöru, eru til pess fallnar að auka á erfiðleika neytandans í pví tilliti.

Detta kallar fram spurninguna um pað hvort gildandi reglur um neytendavernd veiti neytandanum viðunandi undirstöðu til að byggja ákvörðun sína á, pegar að pví kemur að ákveða hvort kaupa skuli viðbótartryggingu eða ekki. Fjallað er um pessa spurningu í kafla 4 í skýrslunni.

Norrænir neytendur eru með kaupum á viðbótartryggingum verndaðir af fjölda reglna í tryggingalöggjöfinni, samninga-, neytendasamninga- og markaðslöggjöfinni auk almennra meginreglna samningaréttar.

Reglur um neytendavernd skylda m.a. tryggingafélög og smásöluverslanir til að veita neytandanum fjölda nauðsynlegra upplýsinga um trygginguna, par með talin tengsl hennar við ríkjandi tryggingavernd samkvæmt kaupalögum og um áhættuna á skörun hennar við hugsanlega innbústryggingu, b.e.a.s. tvítryggingu.

par fyrir utan tryggja reglurnar um neytendavernd upp að vissu marki að hægt sé að grípa inn í, svo fremi sem samningurinn hafi verið gerður á grundvelli villandi upplýsinga eða að hann hafi að geyma ósanngjarna skilmála. Enn fremur njóta neytendur í Danmörku 14 daga réttar til að falla frá samningi; á hinum Norðurlöndunum er réttur neytenda til að falla frá samningi takmarkaður við fjarsölu.

Í dag nýtur neytandinn nú pegar talsverðrar réttarverndar við kaup á viðbótartryggingum. Spurningin er samt sem áður hvort reglurnar séu í framkvæmd fullnægjandi til að tryggja neytandanum nauðsynlegan grundvöll til að meta hvort við tilteknar aðstæður pað sé hagræði af pví að kaupa viðbótartryggingu. Hin réttarpólitísku álitamál varðandi neytendavandamál vegna viðbótartrygginga og nokkrir mismunandi lausnarmöguleikar á bví fá umfjöllun í kafla 5 í skýrslunni. 
Viðbótartryggingar eru fyrir flesta neytendur óaðgengilegt grátt svæði par sem kaupalaga- og tryggingaréttur mætast. Degar tekið er tillit til pess og til umræddra og fremur sérstakra aðstæðna, par sem viðbótartryggingar eru seldar, virðist sem um sé að ræða ákvarðanir, par sem jafnvel hið tiltölulega péttriðna net upplýsingakrafna o.fl. er í reynd oft ekki í stakk búið til að tryggja neytandanum viðunandi ákvörðunargrundvöll.

Afleiðingar pessa er sú hætta að neytandinn meti pað svo við ákvörðunartökuna um trygginguna, að sú óvissa sem ríkir um pað í hvaða mæli neytandinn hafi pörf fyrir viðbótartryggingu leiði til pess að neytandi pori ekki að sleppa pví að kaupa viðbótartrygginguna „til að vera viðbúinn hverju sem að höndum kann að bera“. Баð er pví margt sem bendir til pess að réttarpólitískar ráðstafanir kunni að vera nauðsynlegar til að tryggja norrænum neytendum nægilega vernd við kaup á viðbótartryggingum.

Í kafla 5 er að lokum bent á röð mismunandi svæða par sem vandamál og ýmsar tillögur að hugsanlegum lausnum koma fram.

Bent er á bað sem valkost/viðbót við lagabreytingar að pörf er á bví að hugleiða bað í samvinnu við atvinnu- og neytendasamtök auk neytendayfirvalda að leggja tilteknar línur til stefnumörkunar sem „skapalón“ fyrir

- skilmála viðbótartrygginga sem fela í sér að hluta til ábyrgðarmiklar meginreglur, sem allar viðbótartryggingar skulu fylgja, og að hluta til tillögu að samningu algengustu skilmála viðbótartrygginga.

- skriflegar upplýsingar um sambandið á milli gildissviðs viðbótartrygginga og lágmarksverndar neytandans samkvæmt kaupalögum auk nokkurra útbreiddustu tegunda gildissviða innbústrygginga, pannig að pessi álitamál skýrist eins og kostur er með framkvæmd viðeigandi, ápreifanlegra dæma.

Að búa til „skapalón“ af skilmálum viðbótartrygginga gæti m.a. stuðlað að pví að koma á vissri stöðlun (og samanburðarhæfni) með pví að koma á ásættanlegri, fastmótaðri uppsetningu skilmála, sem reynsla er fyrir að setja inn í viðbótartryggingar. Á hinn bóginn er pað sjálfsagt mikilvægt að skapalónið verði ekki ósveigjanlegt, pannig að pað stríði gegn samkeppni á sviði verðs og gildissviðs.

Dar sem verið er að tala um fyrirkomulag eftirgefanlegra laga, væri pað hinum einstöku fyrirtækjum og smásöluverslunum í sjálfs vald sett hvort pau vildu fylgja skapalóninu og hinum ábyrgðarmiklu meginreglum. Skortur á uppfyllingu peirra gætu pó eftir kringumstæðum verið brot á góðum viðskiptaháttum og/eða góðum tryggingarsiðum og með peim hætti leitt til viðurlaga samkvæmt gildandi reglum í annars vegar markaðssetningar- og hins vegar tryggingalöggjöfinni.

Eitt af peim mjög sérstöku neytendapólitísku vandamálum sem bent er á í kafla 5, felst í pví að viðbótartryggingar, vegna reglna um eigináhættu 
o.fl., hafa pá hættu í för með sér að neytendur sem kaupa pær koma í reynd til með að greiða fyrir að njóta góðs af peim réttindum, sem peir hafa samkvæmt kaupalögum og sem peir hafa pegar greitt fyrir í verði vörunnar.

Sem möguleg lausn eru gerð í skýrslunni drög að tillögu um bann við skilmálum viðbótartrygginga, sem ganga út á að fastákvarða eigináhættu pegar um ræðir að gildissvið hennar nái til skorts á virkni vöru o.fl. yfir tímabil er svarar til lögákveðins kvörtunarfrests vegna galla, p.e.a.s í Danmörku (2 ár) og kannski í Svípjóð (3 ár). Í Finnlandi (bar sem ekki er í gildi neinn ákveðinn kvörtunarfrestur) auk Íslands og Noregs, par sem kvörtunarfresturinn er í yfirgnæfandi fjölda tilvika 5 ár, gæti verið hægt að setja bann gegn eigináhættu í 2 eða 3 ár. bað svarar til pess tímabils par sem ætla má að sönnunarlegt hægræði neytandans sé verulegt af pví að nota viðbótartryggingu fram yfir reglur kauparéttar. 


\section{Summary}

This report has been prepared as part of a Nordic project under the Danish National Consumer Agency, entitled „Tillægsforsikringer ved varekøb" (additional insurances in relation to the purchase of consumer goods). The project is financed by Nordisk Ministerråd.

The purpose of the report is to analyse the area of additional insurances in relation to purchase of consumer goods in the Nordic countries. The report maps out the Nordic market for these insurances, analyses the consumers' knowledge of and need for them, and provides some concluding remarks of legal political nature regarding the future regulation of additional insurances.

The term "additional insurance" is defined as a product insurance that the consumer takes out in a retail shop in connection with the purchase of the product itself. In the UK and US the phenomenon is sometimes known as extended warranties“. Consequently, other types of product insurances, e.g. household insurances, are not covered by the term "additional product insurances".

The market for additional insurances is described in chapter 2 on basis of information obtained through the members of the project group or from ministries/public agencies, consumer complaint boards, consumer and trade organisations, print and electronic news media, the Internet etc.

The obtained information indicates that the consumers in the Nordic countries purchase an additional insurance in approx. $1 / 3$ of all purchases where such insurance is offered. That implies that 3-3.5 Million additional insurances are sold in the Nordic countries annually. It is difficult to estimate the total turnover deriving from this sale, in particular because no official information of this nature is provided by the industry. However, it seems to be indisputable that the market size exceeds an annual turnover of no less than 1 Billion DKK. Thus, the size of the market is substantial.

As regard Denmark, Norway and Sweden the report indicates that the market for additional insurances has the same overall characteristics. Further, the legal problems attached to the insurances are basically the same in these countries. Information about Finland and Iceland is sparse. The differences between the Nordic countries' consumer legislation, e.g. in relation to the duration of the slimitation period pursuant to the sale of goods act, or the existence of a right of withdrawal period, are of course reflected in the wording of the insurances in each of the Nordic countries.

The market for additional insurances is the subject of the report's chapter 2. Additional insurances are primarily being sold in connection 
with sale of consumer durables and electronic goods etc. Some also provide such insurances in connection with other goods such as glasses or cell phones.

As mentioned, additional insurances are being sold through the retailers in connection with the consumer good that the insurance concerns. The payment for the insurance is due in whole at the same time as the payment for the good in question. The sale is being concluded by the retailer, acting as an agent for the insurance company. Consequently, the necessary information about the insurance, the coverage and duration compared to the limitation period according to sales law and a possible household insurance etc. is provided by the retailer's sales personnel.

In return for the provision of the insurances the retailers receive a commission from the insurance companies (the insurance companies being the consumer's contract party). The commission is often times considerable, which obviously creates an extra stimulus for the retailer to sell the additional insurances.

Additional insurances are being sold under many names. For a systematic approach two overall categories can be defined: An "ordinary" and an "extended" additional insurance, respectively. Very many differences exist between the individual insurances, not only between the two overall categories, but also within each of the categories. These differences complicate the description of "a typical" additional insurance.

The coverage of ordinary additional insurances rarely differs significantly from the defects etc. covered by the consumer's rights under the Nordic sale of goods acts. One difference can be that the period of cover under the insurance often times are longer than the limitation period under the sale of goods acts. Another possible difference can be that the insurance also covers certain incidents besides product defects and thus provides coverage beyond that of the sales of goods acts. On the other hand there are often other clauses in the insurance policy that reduce the consumer's legal position in comparison with the rights under the sale of goods act, e.g. regarding depreciation or self risk.

Compared to the ordinary additional insurances the extended ones typically have a larger scope of cover, less or no self risk, less or no depreciation or other advantages. The increased cover is, of course, being paid for by an increased insurance price.

The price of an additional insurance normally amounts to $10-20 \%$ of the price of the insured product. As regard inexpensive consumer products the price of the insurance can be relatively higher. Inversely, the price can be relatively lower for insurances connected with expensive products.

Supply of additional insurances is widespread among larger retail chains, primarily those who cover private household products, consumer durables goods and electronic goods. Many of the suppliers are cross Nordic. Similarly most of the underlying insurance companies with 
whom the consumer enters the insurance contract, are identical across the Nordic countries. The total number of insurance companies that supplies additional insurances in co-operation with the retailers seems to be modest.

Information indicates that additional insurances are being activated in $30-40 \%$ of the situations where the additional insurance has been bought. The products where the insurance is activated most often are expensive TV's, washing machines and dishwashers. The most rarely activated additional insurances are those purchased in connection with stoves, refrigerators and inexpensive music systems.

The crux of the matter in relation to additional insurances is the extent to which they provide the consumer any additional benefits, considering the "safety" that the consumer already enjoys under the sale of goods act, a possible product guarantee and the household insurance taken out by the vast majority of the Nordic households. This question is dealt with in chapter 3.

Based on the comparison between the most common additional insurances and the consumers' rights pursuant to the sale of goods act, it is concluded that additional insurances generally do not provide the consumers with a greater safety in case of a functional defect than do the rights under the sale of goods act, until some longer time has passed after the purchase of the product. Exactly how long time that shall pass after the purchase depends mainly on the type of consumer product in question. The extended safety that can be bought with an additional insurance consists of the following:

- The period of coverage under the additional insurance is longer than the limitation period according to the sale of goods act, i.e. 2 years (Denmark), 3 years (Sweden), 5 years (or just 2 years, as the case may be, in Norway and Iceland); In Finland there is no statutory limitation period at all.

- Due to the additional insurance the consumer can - 6 month or more after the purchase - possibly gain a certain advantage in terms of burden of proof, because the insurance implies that relevant factual doubt concerning the cause of the functional defect etc. legally benefits the consumer.

However, the additional insurance does not give the consumers any additional safety in the respects just mentioned in so far as the goods in question fall within the scope of a commercial product guarantee issued by the seller or a third party, e.g. the manufacturer. Furthermore, the coverage under an additional insurance normally does not match the remedies from which the consumer can benefit under the sales of goods act in case of non-conformity. This is partly due to the fact that the additional insurances often contain terms concerning the consumer's self risk etc. and 
partly the prohibition against enrichment which is one of the general principles of insurance law.

One of the facts that can trigger coverage under an additional insurance is in some, but not all cases, external events occurring after the passing of the risk to the consumer (and not caused by the seller's breach of contract). This is an extra benefit for the consumer unless the event in question falls with in the scope of the consumer's home insurance.

A typical home insurance covers damage caused by fire, water, theft etc, i.e. external events causing damage to the insured object. In contrast, the typical additional insurance covers functional defects, technical breakdown etc., i.e. inherent defects. As a starting point the two kinds of insurance coverage do not overlap.

In practice, however, the difference between the two types of insurance coverage is not all that clear because the consumer can often choose between different categories of coverage under both a home insurance and an additional insurance. On this background it can be hard for the individual consumer to find out, to what extent the additional insurance in fact increases the consumer's pre-existing level of security. The special circumstances under which the additional insurances are taken out in the retail shop as an accessory to the purchase of goods in question are likely to enhance the said difficulties of the consumer.

This raises the question whether the existing consumer protection rules ensure a satisfactory basis of information for the consumer to decide upon taking out an additional insurance. This question is dealt with in chapter 4 of the report.

When taking out an additional insurance Nordic consumers are protected by various rules of the insurance legislation and the general legislation on consumer contracts and marketing law as well as the general principles of contract law

According to the consumer protection law insurance companies and retail sellers are obliged to inform the consumer of some of the essential questions concerning the additional insurance, e.g. the consumer protection according to sales law and the risk of overlap between the home insurance and the additional insurance.

Furthermore, the consumer protection rules to a certain extent protect the consumer if the additional insurance is taken out on the basis of misleading information or if it contains unfair contract terms. In addition, Danish consumers have a general right of withdrawal within a 14 days period from insurance contracts whereas consumers' right of withdrawal in the other Nordic countries is limited to distance sale of insurance.

Although the level of the legal consumer protection of Nordic consumers taking out an additional insurance is rather high the question is whether the rules are sufficient to ensure in practice that the consumer has a sufficient basis to decide whether he or she will profit from taking out an additional insurance 
The legislative questions concerning additional insurance and some of the various possible ways of solving the problems are dealt with in chapter 5 .

The additional insurances confront consumers with a difficult combination of questions concerning sales law and insurance law. On this background and considering the rather special practical circumstances under which additional insurances are taken out even the relatively elaborate information requirements in practice are often not sufficient to ensure the consumer a satisfactory basis for the decision whether to take out an additional insurance.

Consequently, there is a risk that the consumer because of uncertainty concerning his or her real need of the insurance does not dare to refrain from taking out the insurance „just in case“. Therefore, legislative action can be necessary in order to secure Nordic consumers satisfactory protection when taking out additional insurance.

In chapter 5 is pointed on possible soft law regulation as an alternative or supplement to legislation and as the result of a cooperation between business and consumer organisations and consumer agencies. The soft law regulation could consist of concrete guidelines

- mentioning the overall principles applicable to all additional insurances and suggesting the wording of some important contract terms typically found in additional insurances and

- giving concrete examples of the written information to the consumers concerning the relation between the additional insurance coverage and the minimum protection of consumer buyers according to sales law and some of the most common types of home insurance coverage in a way that illustrates the questions so far as possible by relevant and practical concrete examples.

The suggested soft law regulation of the contract terms could among other things promote a certain standardization and the comparison of terms by formulating acceptable terms often found in additional insurance contracts. On the other hand, it is important that the soft law regulation does not counteract competition on price and coverage.

Even though it would be a voluntary matter for the insurance companies and the retail stores whether they would comply with the guidelines non-compliance could according to circumstances amount to a violation of good marketing practices and/or good insurance practices and as such trigger prospective regulation (injunctions) according to the general clauses of marketing and insurance legislation.

One of the more specific consumer problems dealt with in chapter 5 is the risk created by additional insurance contract terms on the consumer's payment of a self risk. Thus, terms on self risk may have the effect that 
the consumer in practice because of the additional insurance coverage will have to pay a self risk in order to benefit from the legal protection according to the mandatory rules of sales law already paid for when the consumer paid for the product covered by the additional insurance.

As a possible solution the report points in the direction of a prohibition against additional insurance contract terms stipulating a self risk in the case of functional defects that appear in a period no longer than the limitation period according to sales law, i.e. in Denmark (2 years), and maybe in Sweden (3 years). In Finland (where sales law stipulates no limitation period at all) and in Iceland and Norway (where the limitation period in most of the practically relevant cases is 5 years) maybe a prohibition against self risk should be 2 or 3 years matching a period after which the advantage of the consumer in terms of evidence by activating the insurance instead of the remedies of sales law on an average can have significant and practical effects to the benefit of the consumer. 


\section{Bilag 1: Udbydere af tillægsforsikringer i de nordiske lande}

I forbindelse med udarbejdelsen af denne rapport er følgende virksomheders tillægsforsikringer undersøgt:

\begin{tabular}{ll}
\hline Virksomhed & Betegnelse for tillægsforsikring \\
\hline Fona A/S & Serviceforsikring \\
(ejes af F Group A/S, Danmark) & X-TRA Serviceforsikring \\
Merlin A/S & Standard Forsikring \\
& Luksus Forsikring \\
Sibas Computer City A/S & Tryghedsforsikring \\
Elgiganten A/S & Tryghedsforsikring \\
Elgiganten AB & Happy Care Produktförsäkring \\
(Elgiganten ejes af Elkjøp, Sverige) & \\
Electric City & Serviceforsikring \\
(ejes af F Group A/S, Danmark) & X-TRA Serviceforsikring \\
Punkt 1 & Tryghedssikring \\
(ejes af Expert, Norge) & Udvidet Tryghedssikring \\
Photocare Fmba & Produktforsikring \\
Zitech Computer ApS & All risk forsikring, Special \\
(hovednavn: Remedan af 1985 ApS) & All risk forsikring, Total \\
Uni-Shop & Totalforsikring \\
ONOFF Sverige AB & BAS Försäkring \\
SIBA AB & PLUS Försäkring \\
Expert ASA & Trygghedsförsäkring \\
Elkjøp AB & Trygghetsforsikring \\
\hline & Trygghetsforsikring \\
\hline &
\end{tabular}





\section{Bilag 2: Eksempler på tillægsforsikringer}

Dette bilag indeholder en række eksempler på anvendte tillægsforsikringer (såvel standard-tillægsforsikringer som udvidede tillægsforsikringer) $\mathrm{i}$ Norden. Eksemplerne er valgt dels ud fra udbyderens størrelse på markedet (idet det primært er de største udbyderes tillægsforsikringer, der er medtaget), dels ud fra, om tillægsforsikringen dokumenterer det i rapporten beskrevne ved at indeholde vilkår, der illustrerer en gennemgående tendens vedrørende tillægsforsikringer, eller undtagelser til en sådan.

Standard-tillægsforsikringerne findes også som pdf-filer på www.norden. org/pub/sk/showpub.asp?pubnr=2006:524.

\section{Standard-tillægsforsikringer (med links til elektronisk udgave)}

Bilag 2.1

Standardforsikring fra Merlin (Danmark)

Merlin Forsikring

Merlin forsikringsbetingelser

Bilag 2.2 Serviceforsikring fra Fona (Danmark)

(foreligger ikke elektronisk)

Bilag 2.3 Basisforsikring fra ONOFF (Sverige)

$\underline{\text { OnOff Basis }}$

Bilag 2.4 Tryghedssikring fra Punkt1 (Danmark)

$\underline{\text { Punkt1 }}$

Bilag 2.5 Trygghetsförsäkring fra Expert (Sverige)

Expert SE

Bilag 2.6 Trygghetsforsikring fra Expert (Norge)

Expert NO

Bilag 2.7 Tryghedsforsikring fra Sibas Computer City (Danmark)

Computer City 
Bilag 2.8 Serviceforsikring fra Electric City (Danmark) Electric City

Bilag 2.9 All Risk Special forsikring fra Zitech Computer (Danmark)

Zitech

Zitech all risk

Bilag 2.10 Trygghetsförsäkring fra SIBA (Sverige) $\underline{\text { SIBA SE }}$

Bilag 2.11 Brilleforsikring fra Brilleland (Norge)

Brilleland NO

Bilag 2.12 Uhellsforsikring fra Euronics (Norge)

Euronics hvitte- eller brunevarer

Euronics tele og mobil

Udvidede tillcegsforsikringer

Bilag 2.13 Luksus Forsikring fra Merlin (Danmark)

$\underline{\text { Merlin luksus }}$

Bilag 2.14 Udvidet Tryghedsforsikring fra Punkt1 (Danmark)

Punkt1 udvidet (samme link som under bilag 2.4)

Bilag 2.15 X-TRA Serviceforsikring fra Fona (Danmark)

(foreligger ikke elektronisk)

Bilag 2.16 PLUS Forsikring fra ONOFF (Sverige)

OnOff PLUS1

OnOff PLUS2

$\underline{\text { OnOff PLUS3 }}$

Bilag 2.17 Happy Care Produktförsäkring fra Elgiganten (Sverige)

Elgiganten SE

Happy Care SE

Bilag 2.18 Happy Care Produktforsikring fra Elgiganten (Danmark)

Elgiganten DK

Happy Care DK

Bilag 2.19 Happy Care Produktforsikring fra Elkjøp (Norge)

Elkjøp NO

Happy Care NO 
Bilag 2.20 Safety+ Produktforsikring fra Lefdal (Norge) $\underline{\text { Safety }+ \text { NO }}$

Bilag 2.21 X-TRA Serviceforsikring fra Electric City (Danmark) Electric City X-TRA (samme link som under bilag 2.8) 